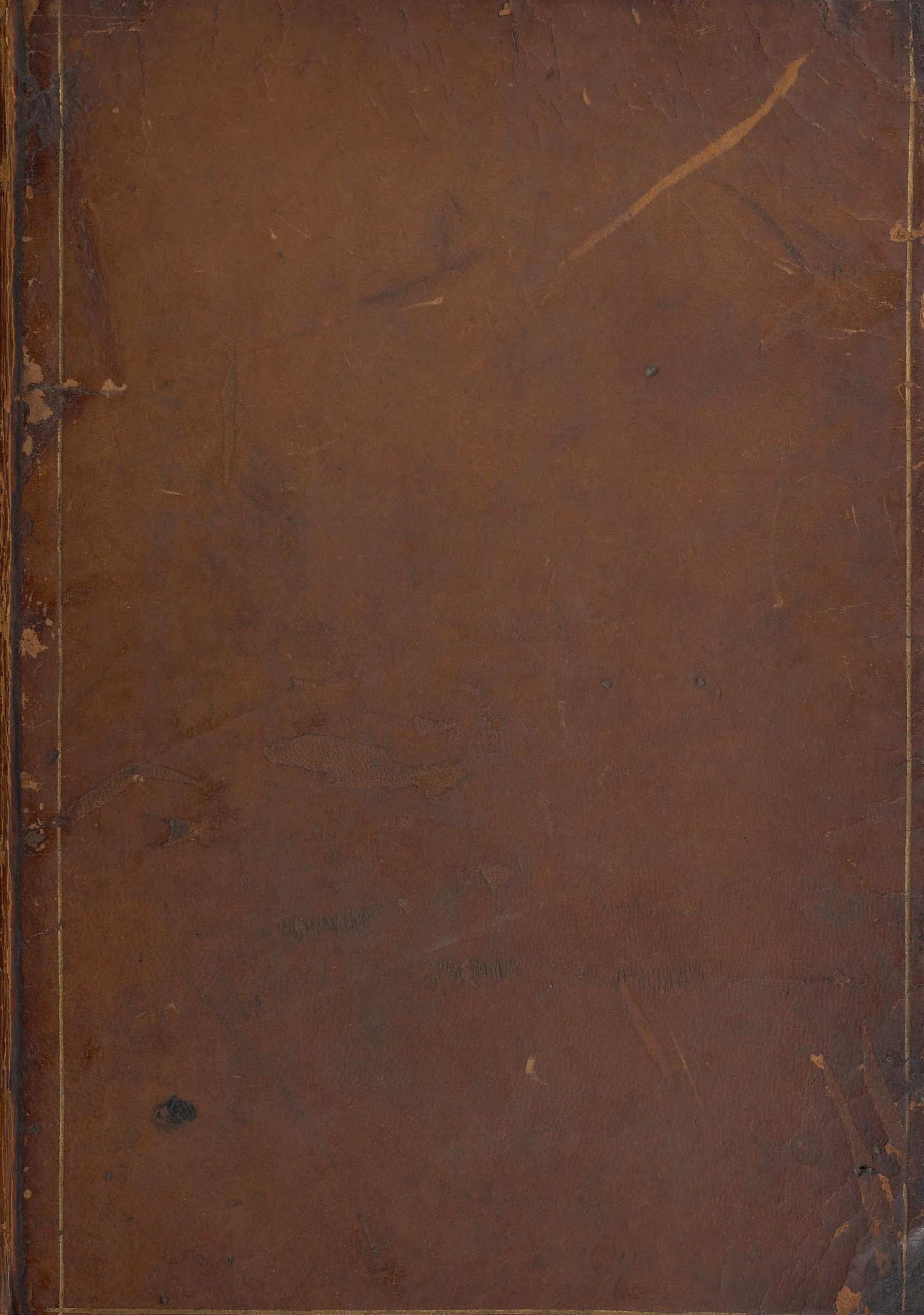




\section{folume Larissime.}

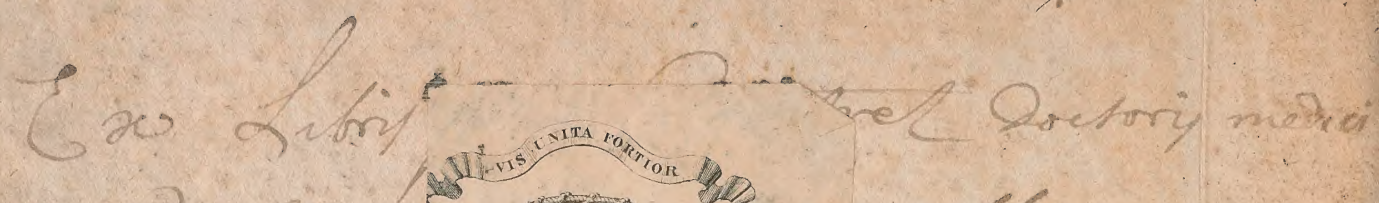

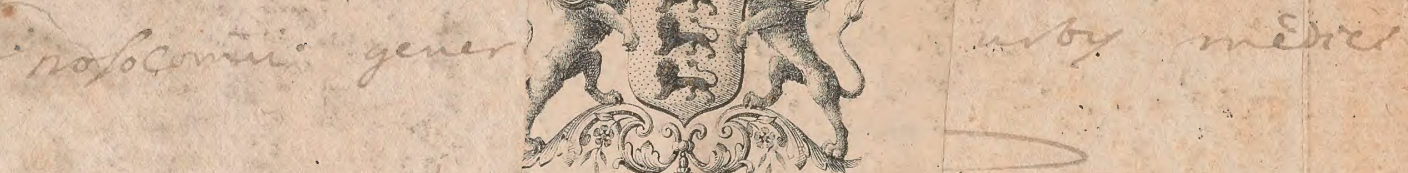

$$
\begin{aligned}
& \text { P3itrituthinte }
\end{aligned}
$$

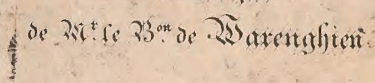

$$
\begin{aligned}
& \text { Ix libios Lenal } 1 . . \\
& \begin{array}{l}
\text { Ranilia....... } \\
\text { 1sbe } \\
\text { Piver Yalle }
\end{array} \\
& \text { ext n' à Orlián. } \\
& 50 \text { pro } \\
& \text { tc. }
\end{aligned}
$$







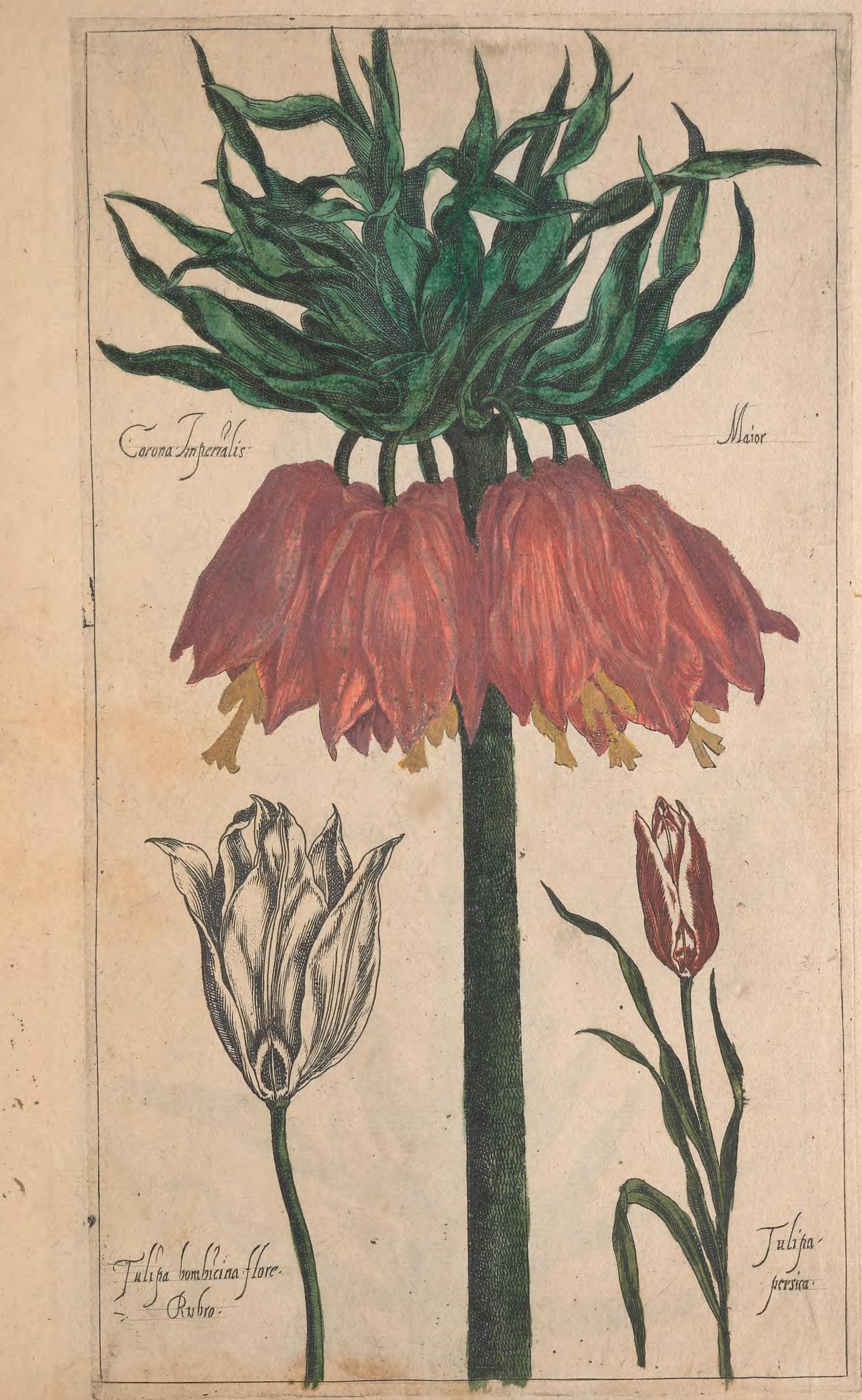

U186. 



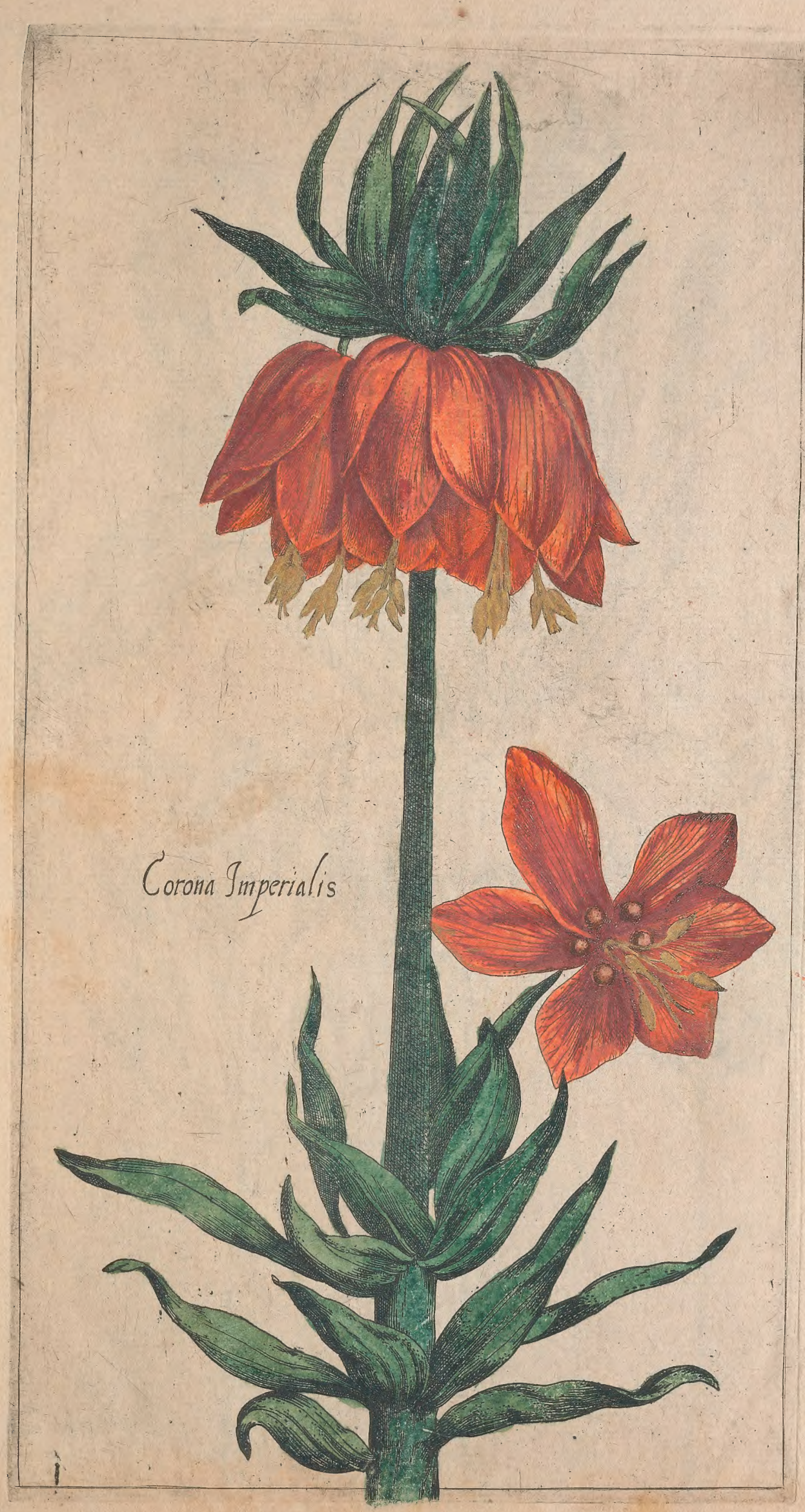





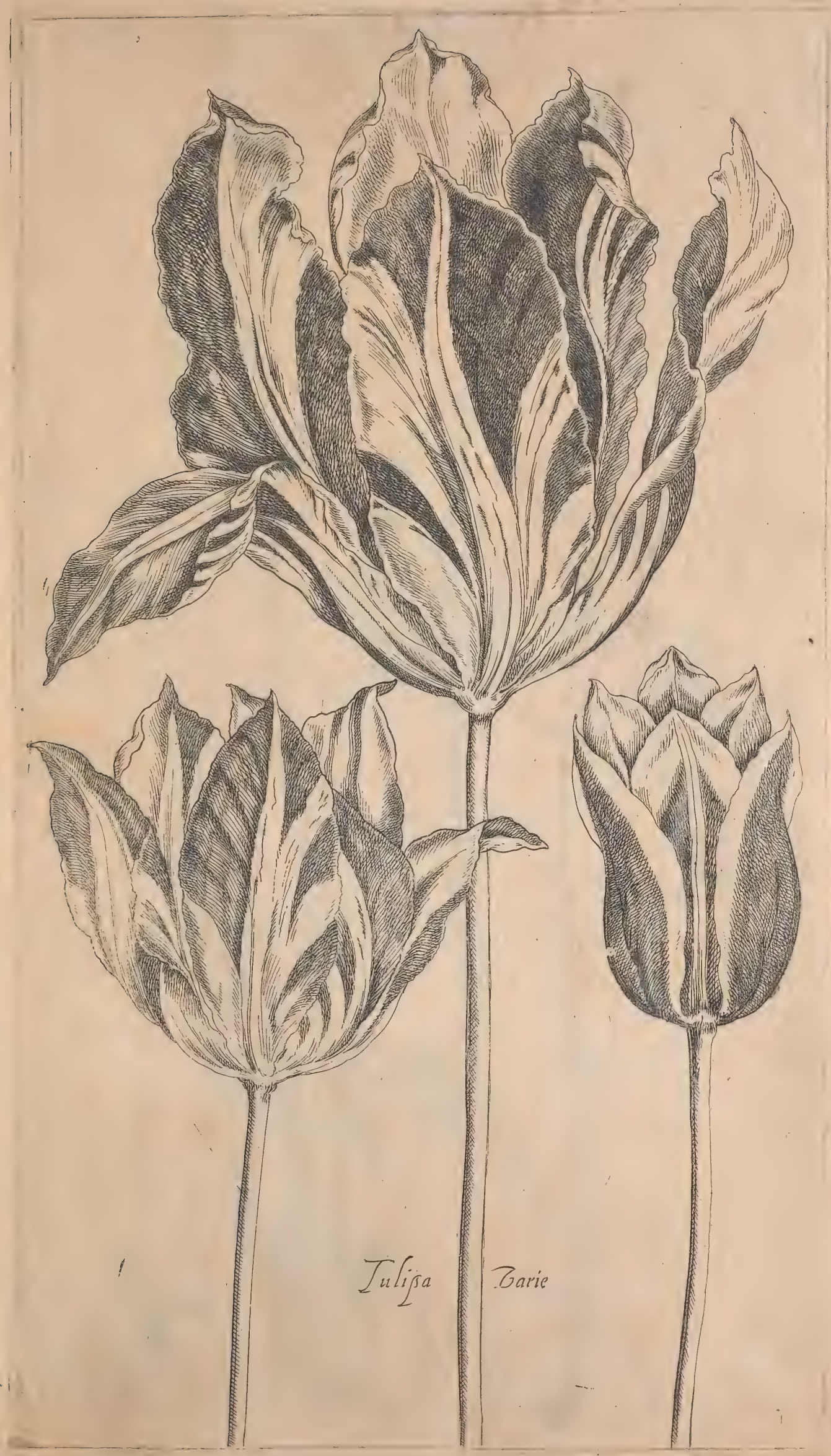





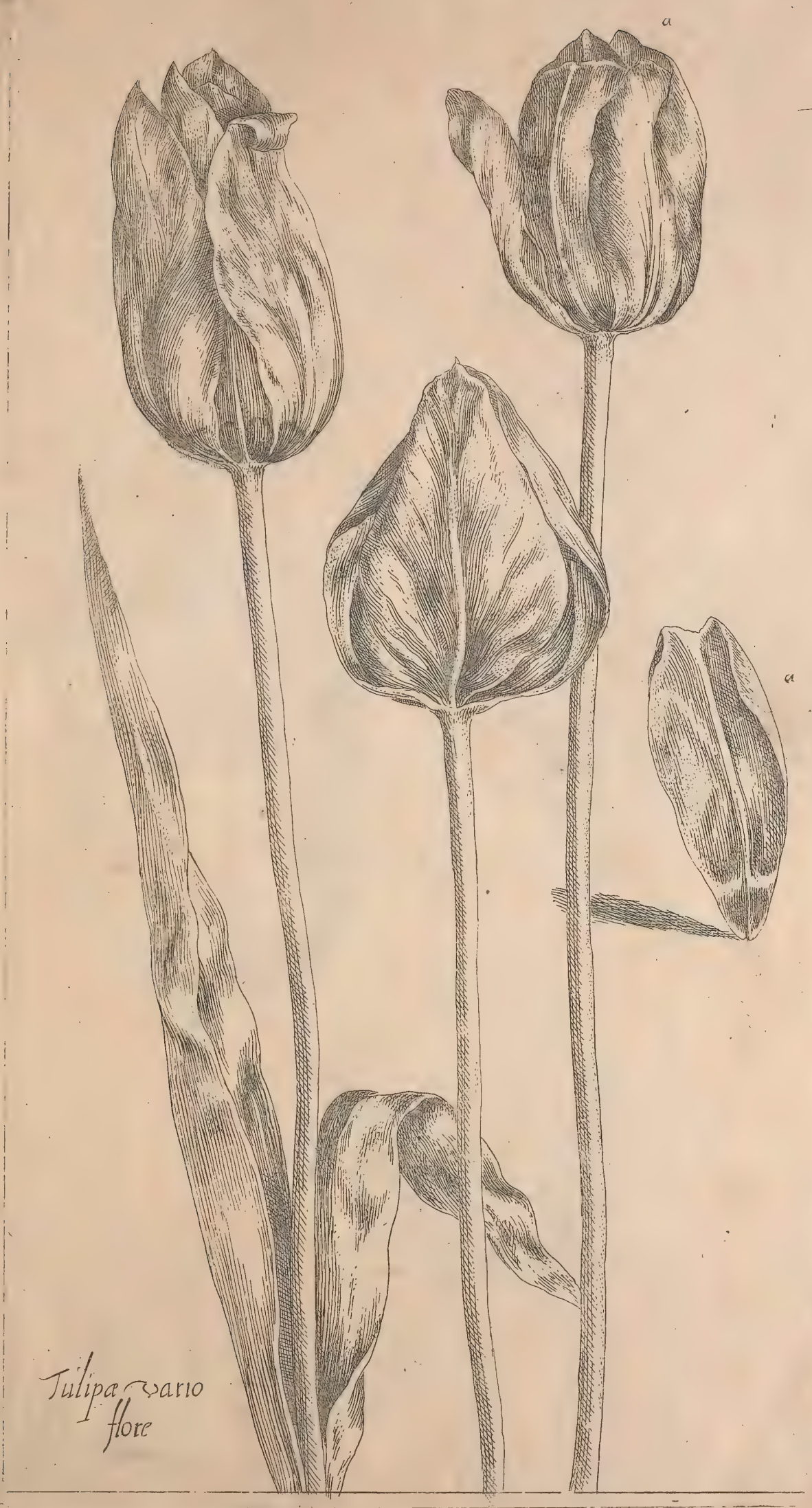





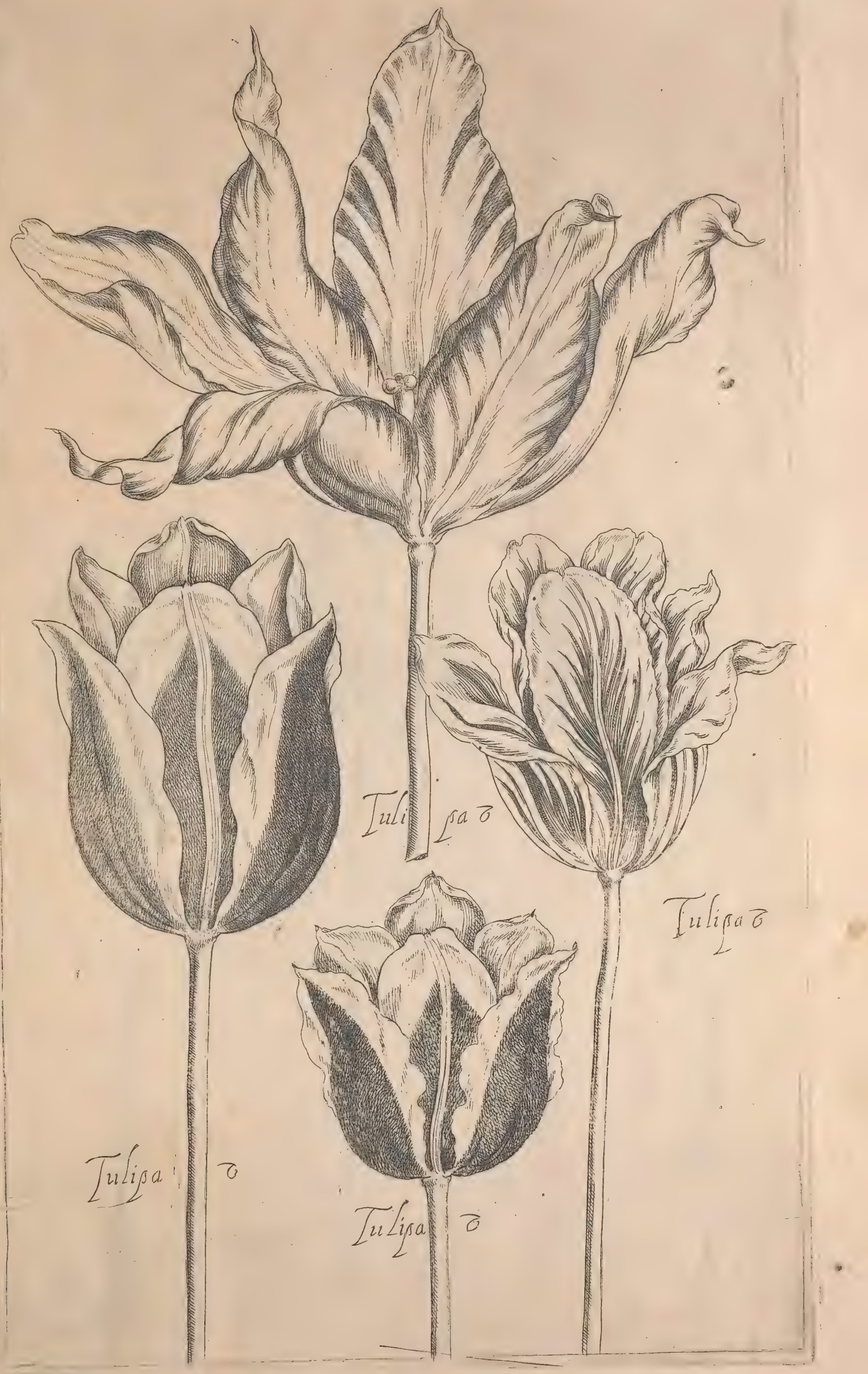





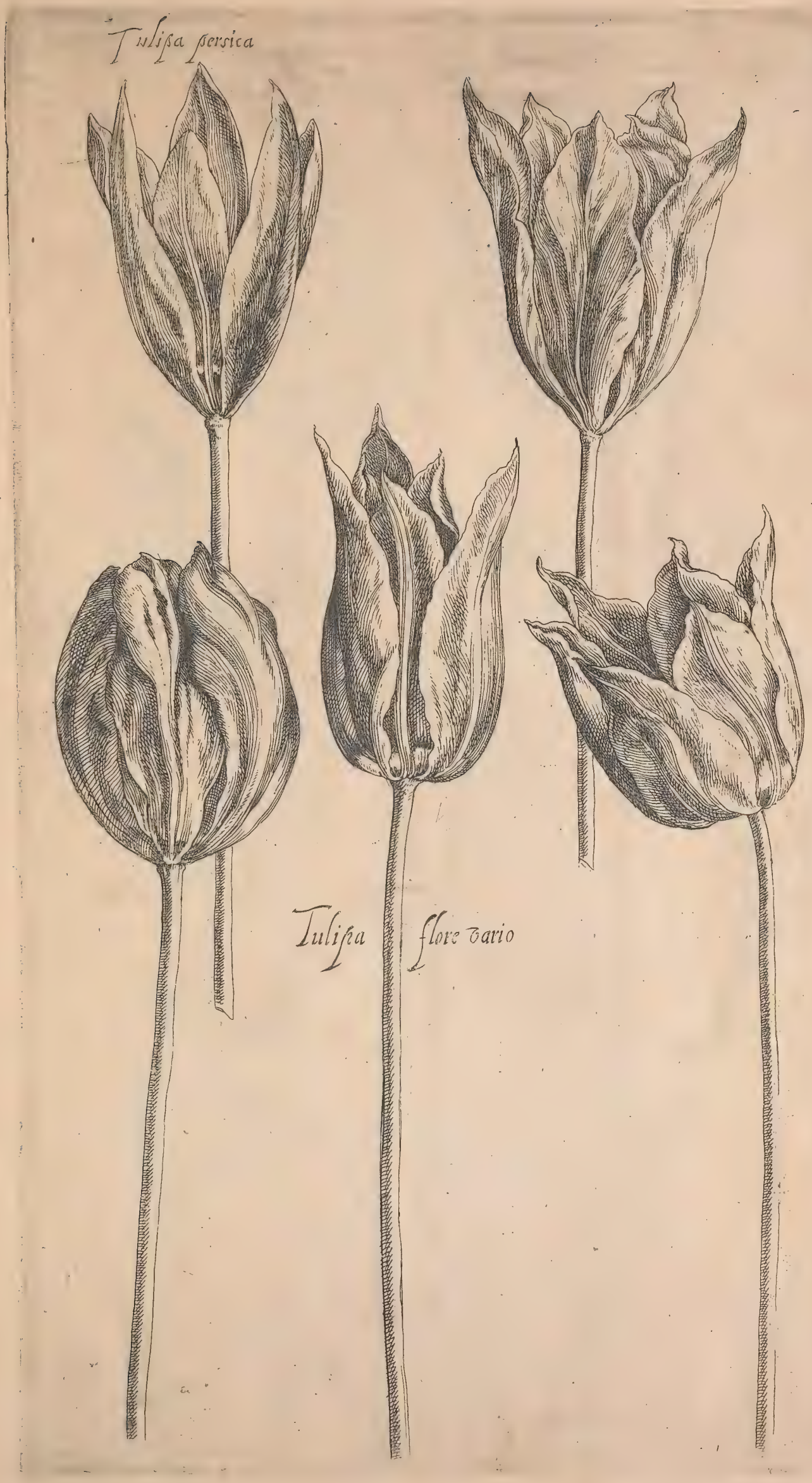





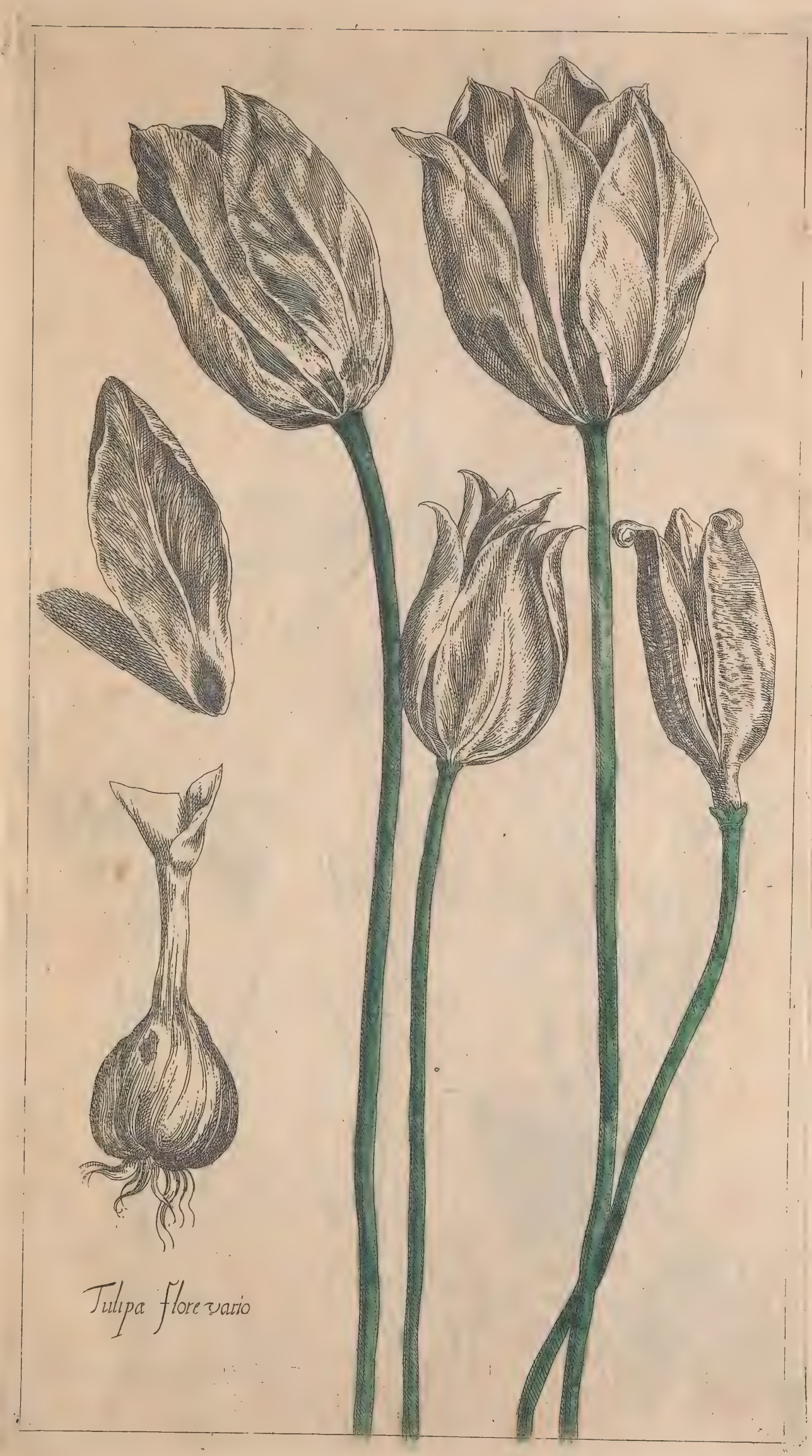




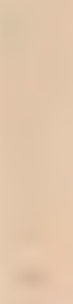




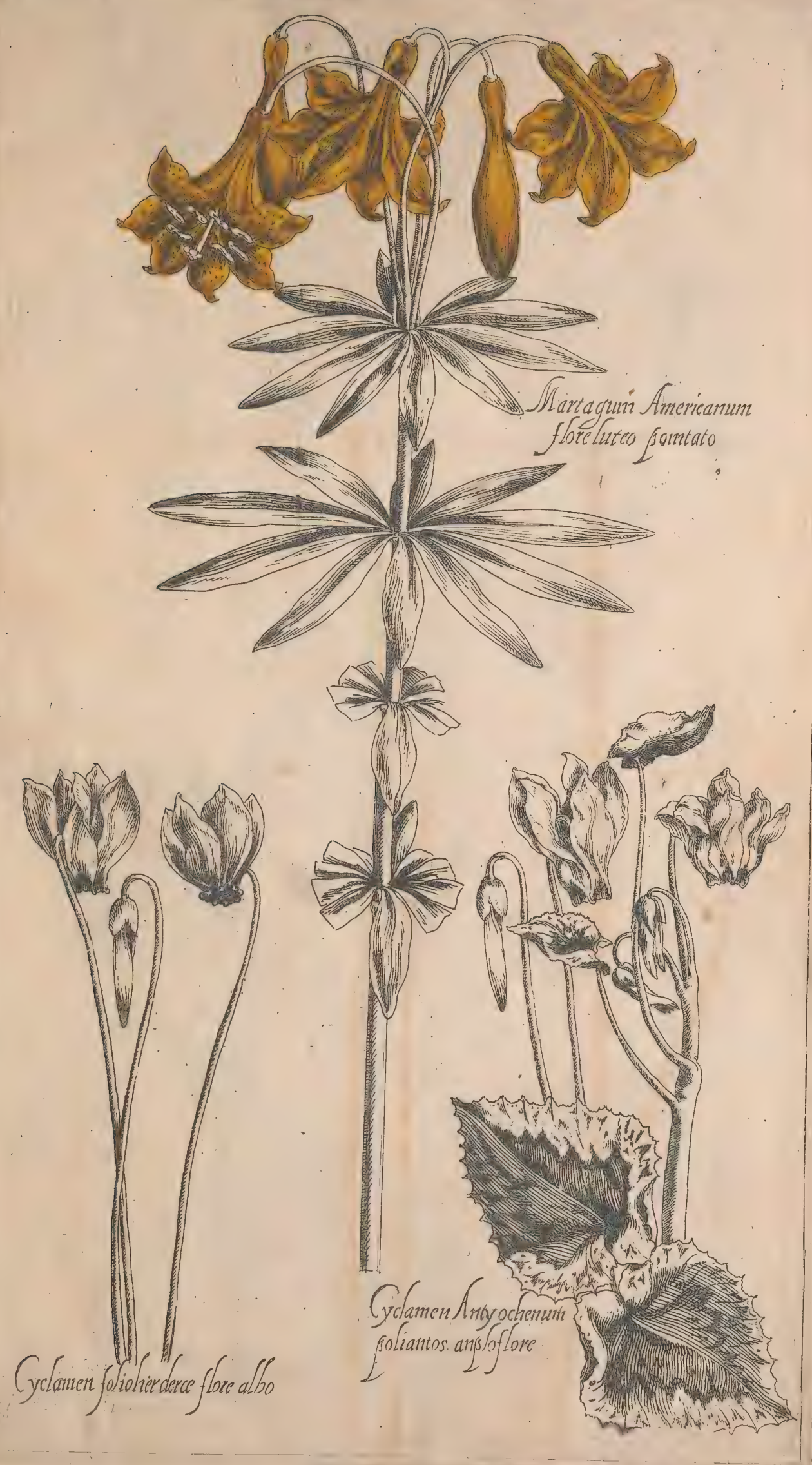





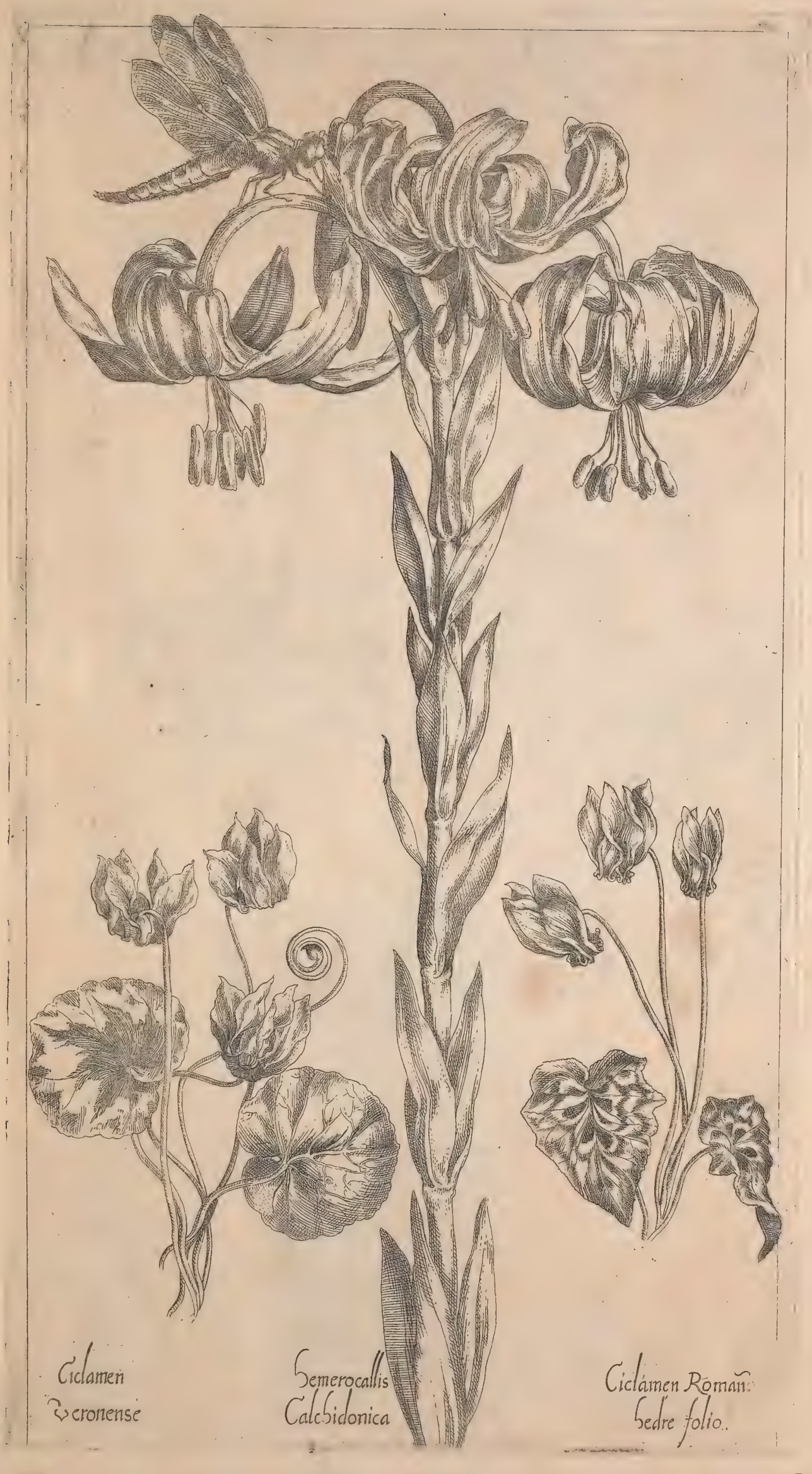





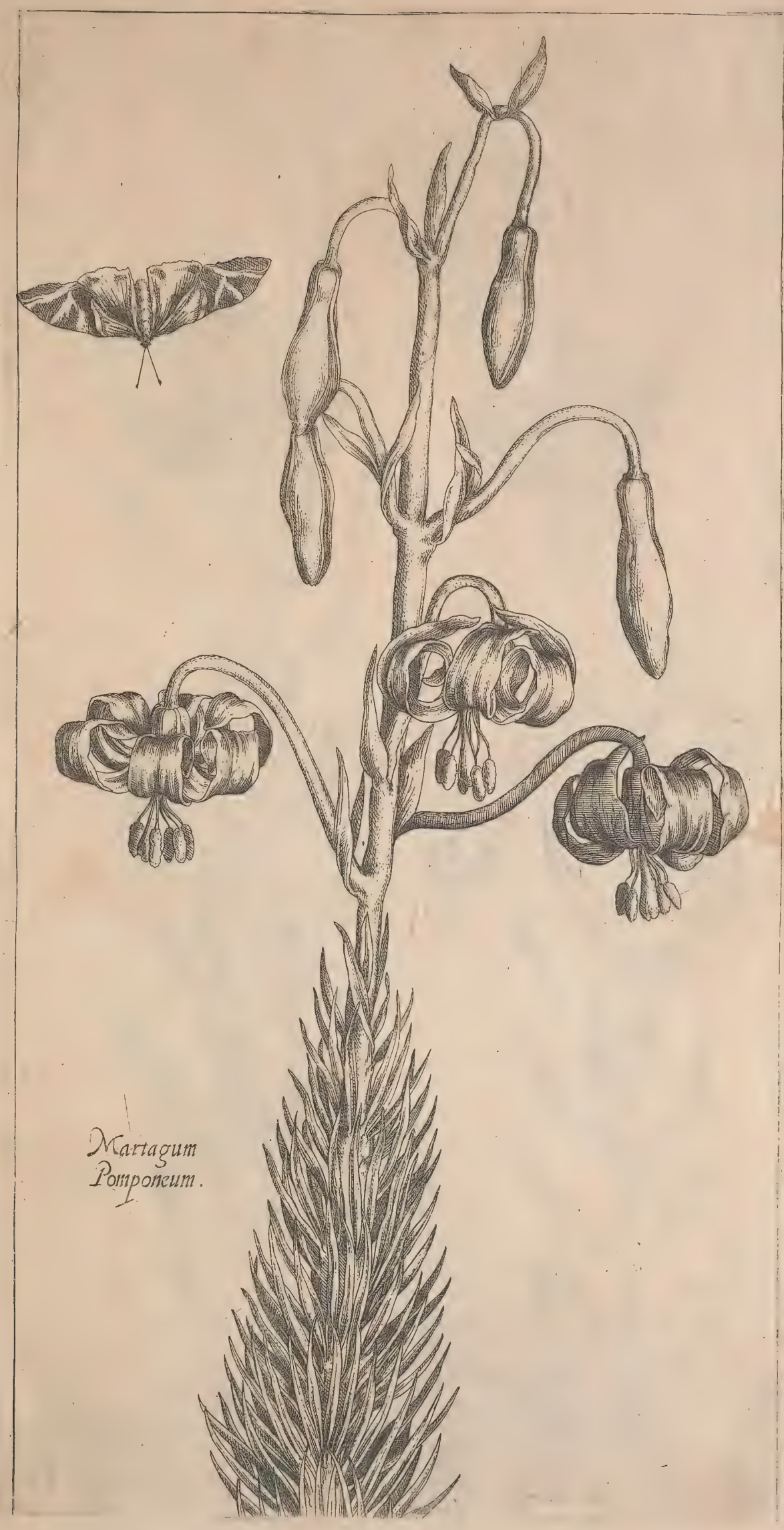




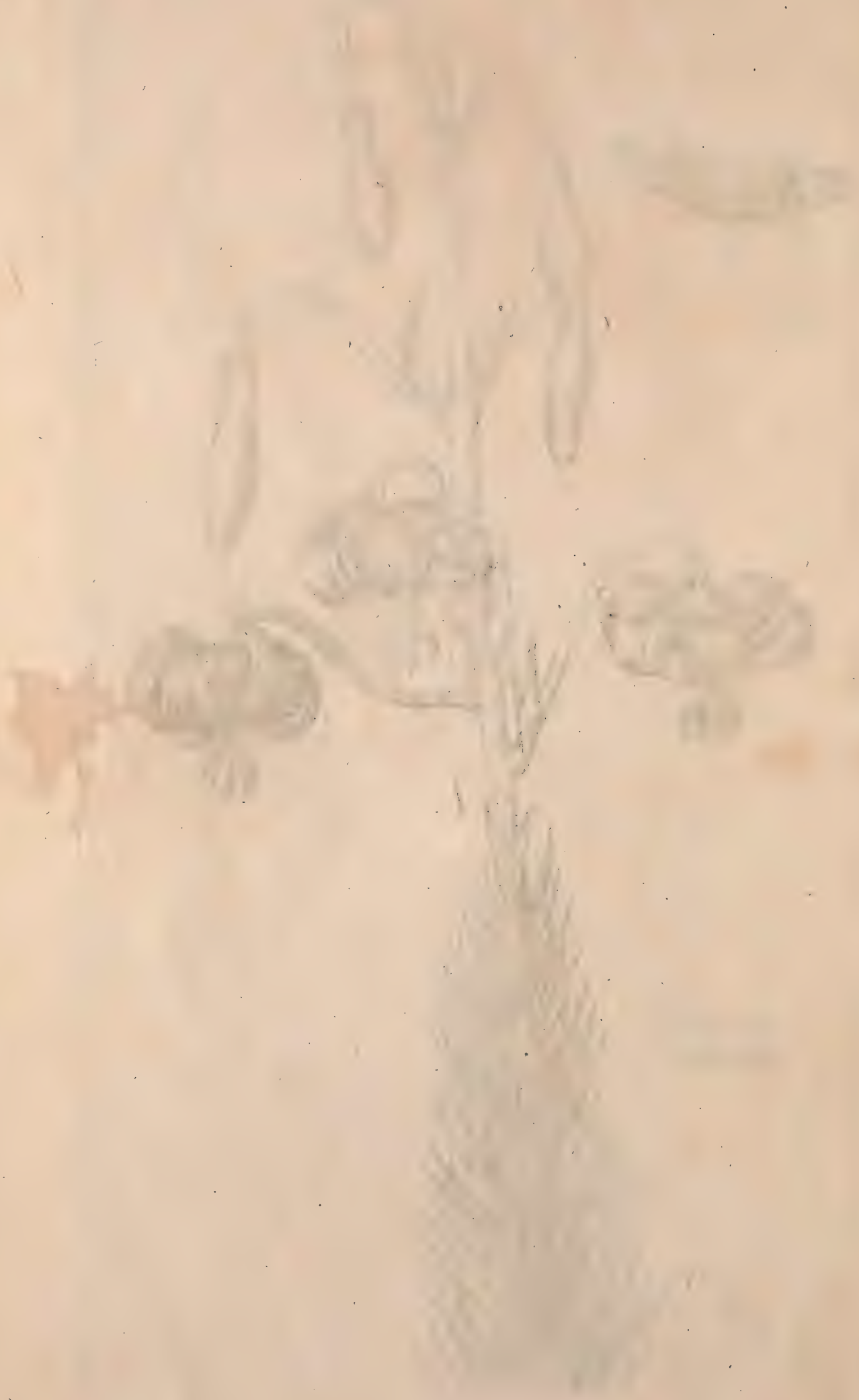




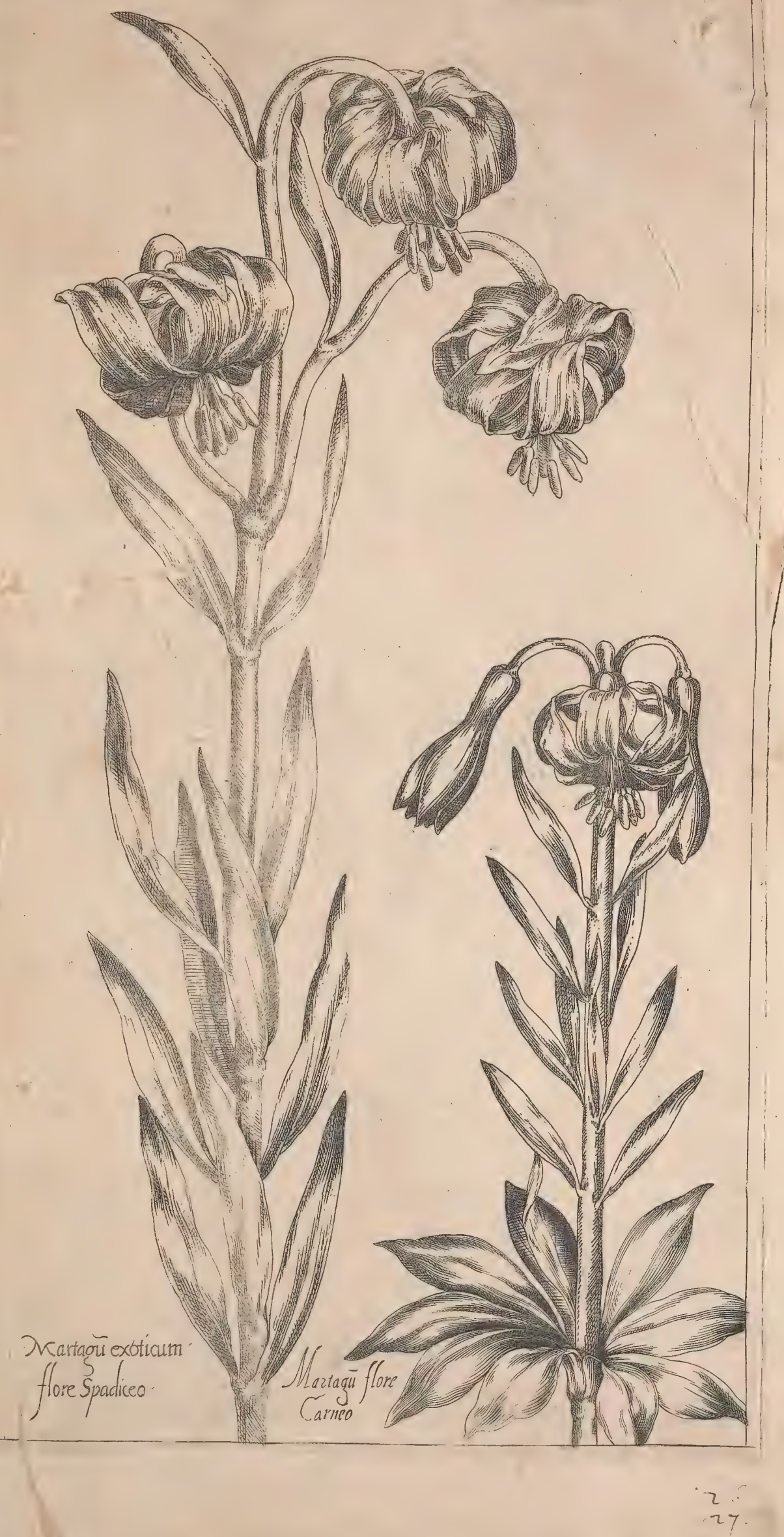





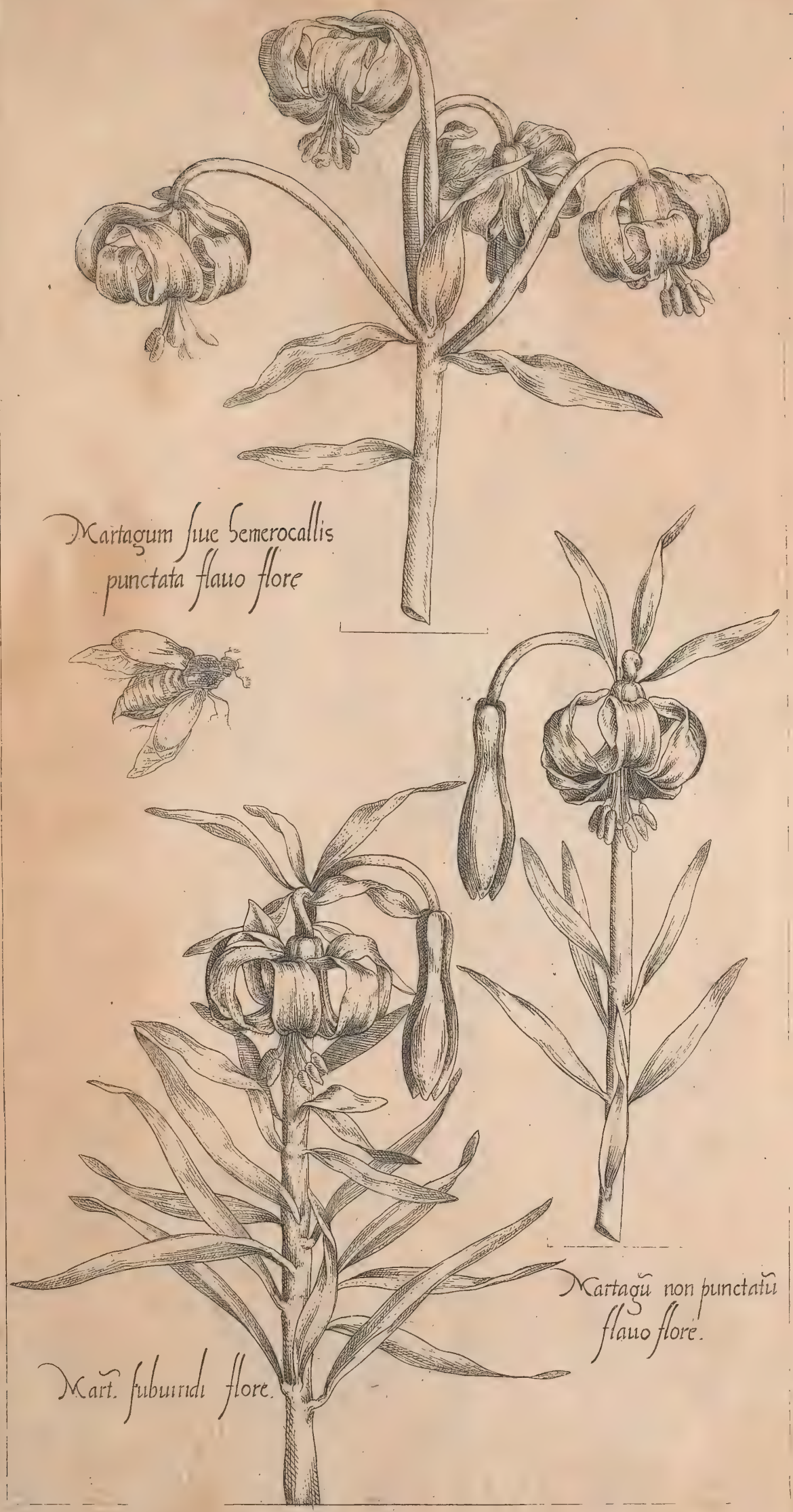





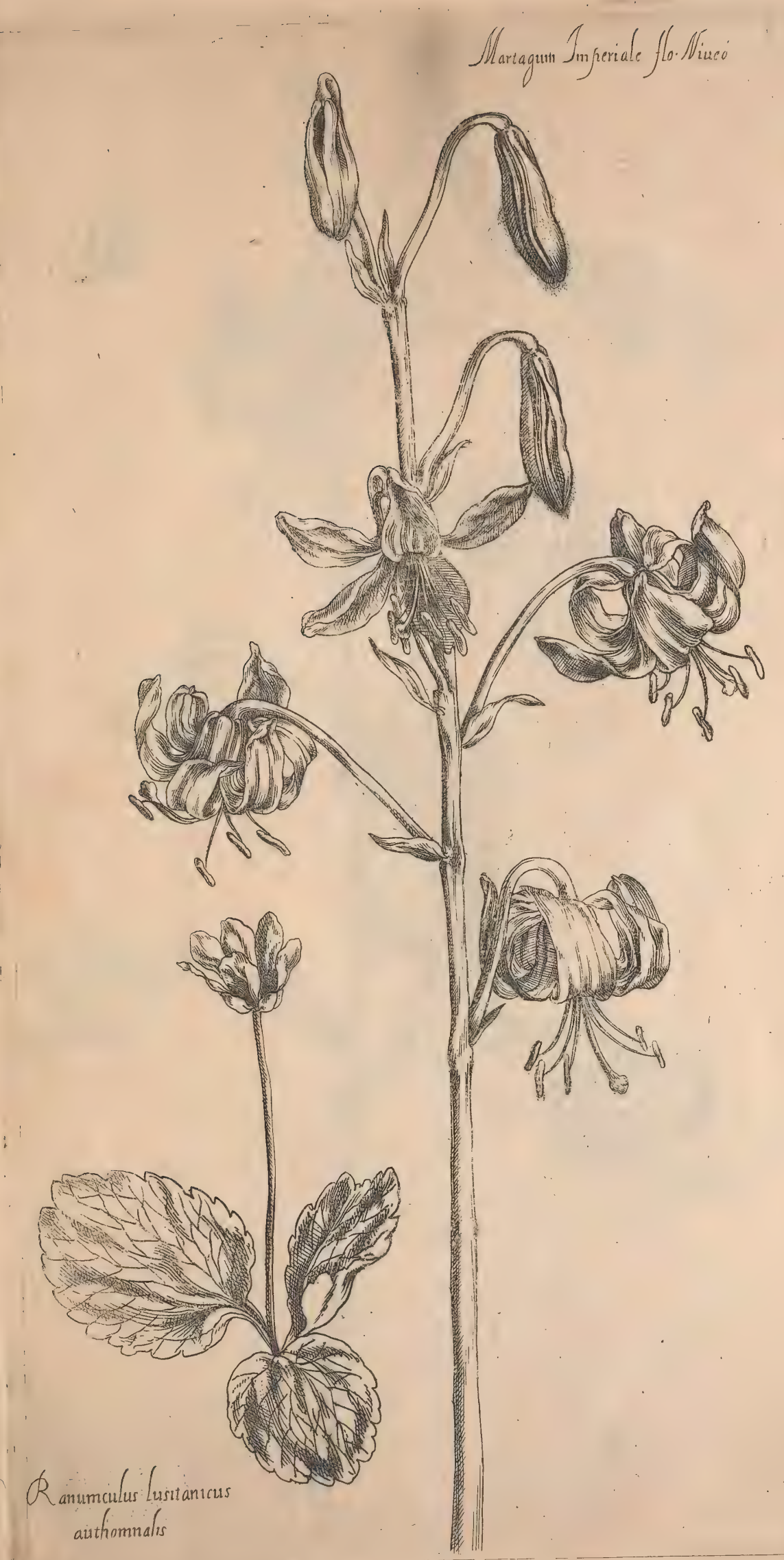





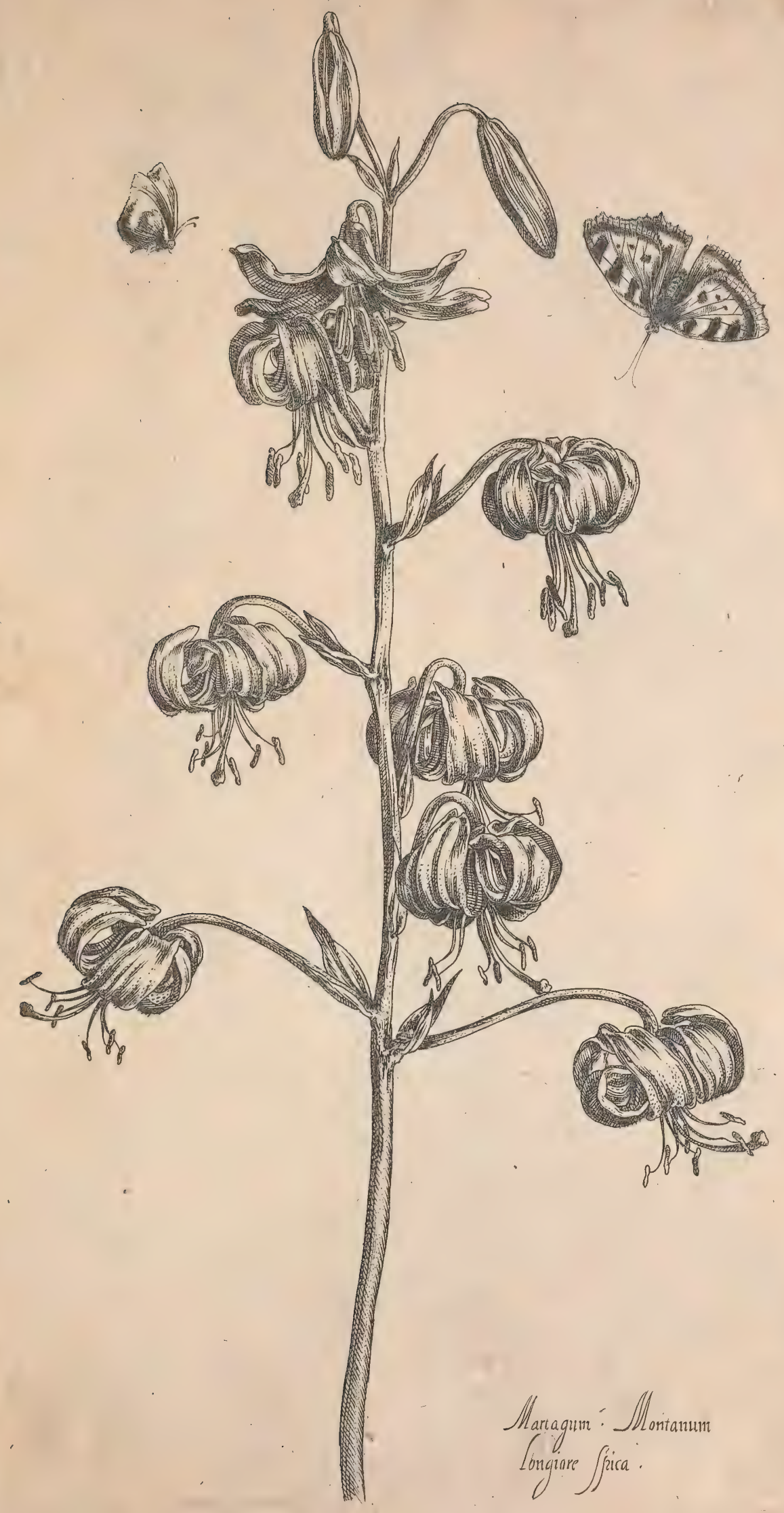





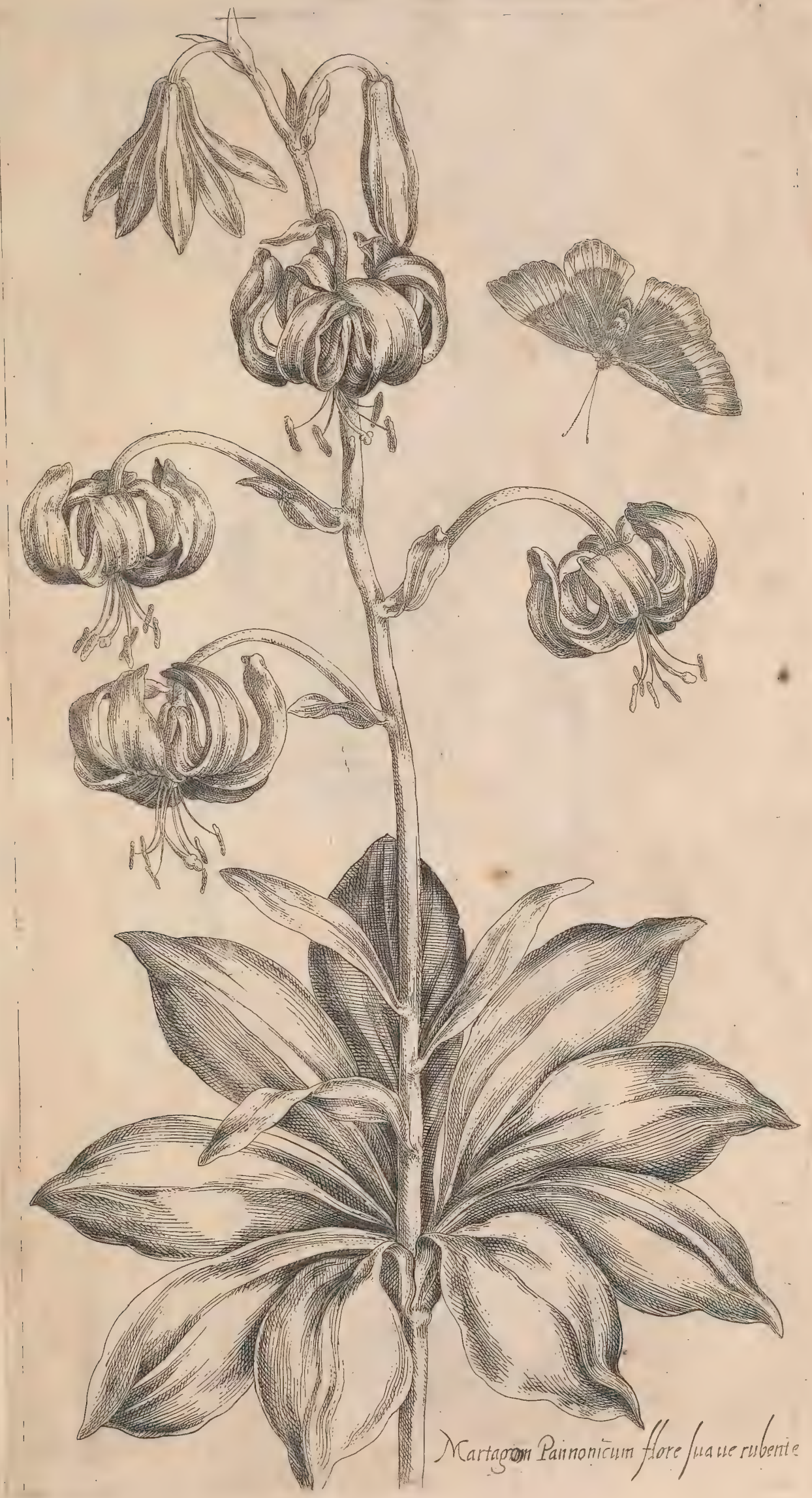





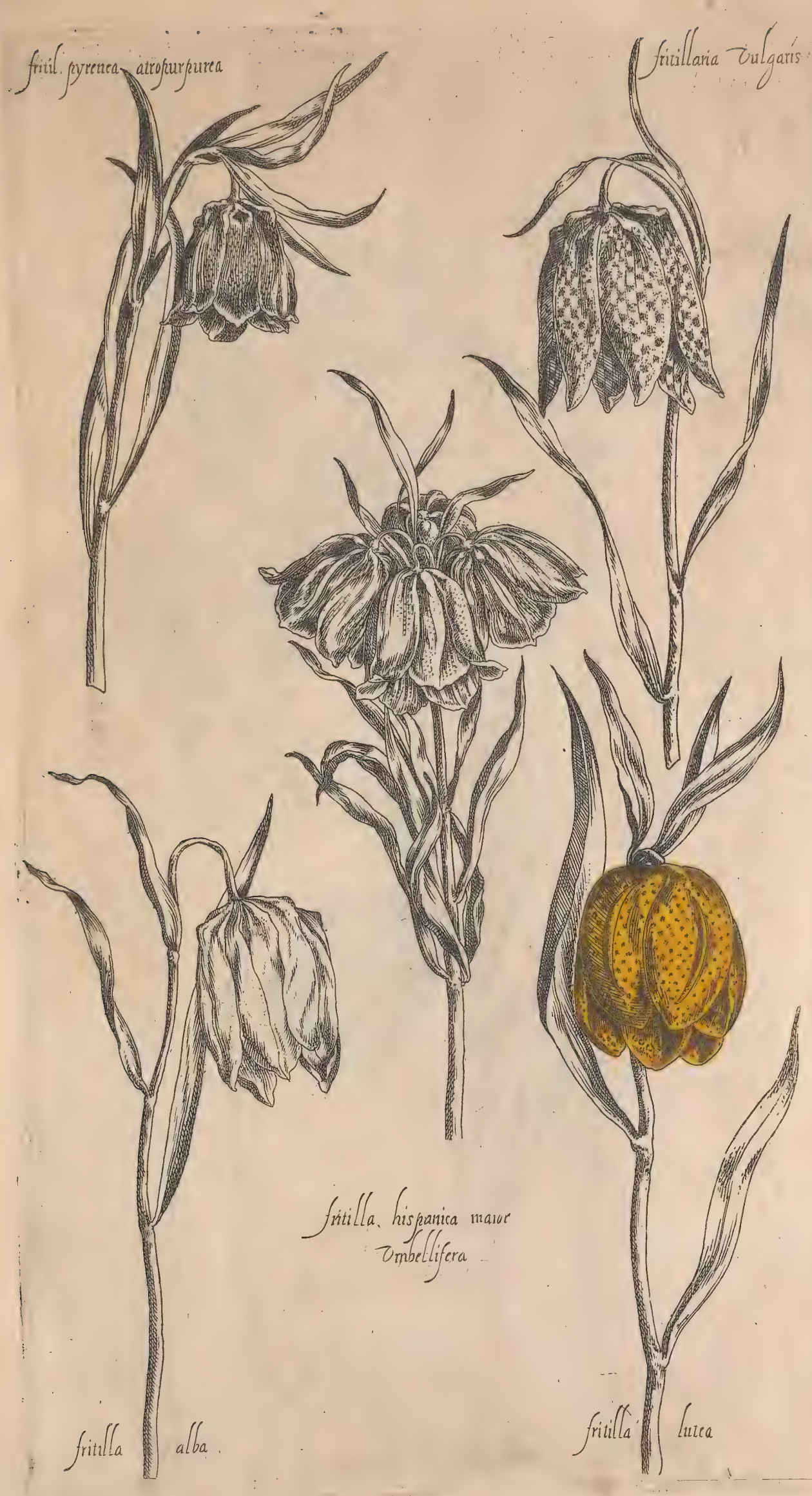


ำ a 


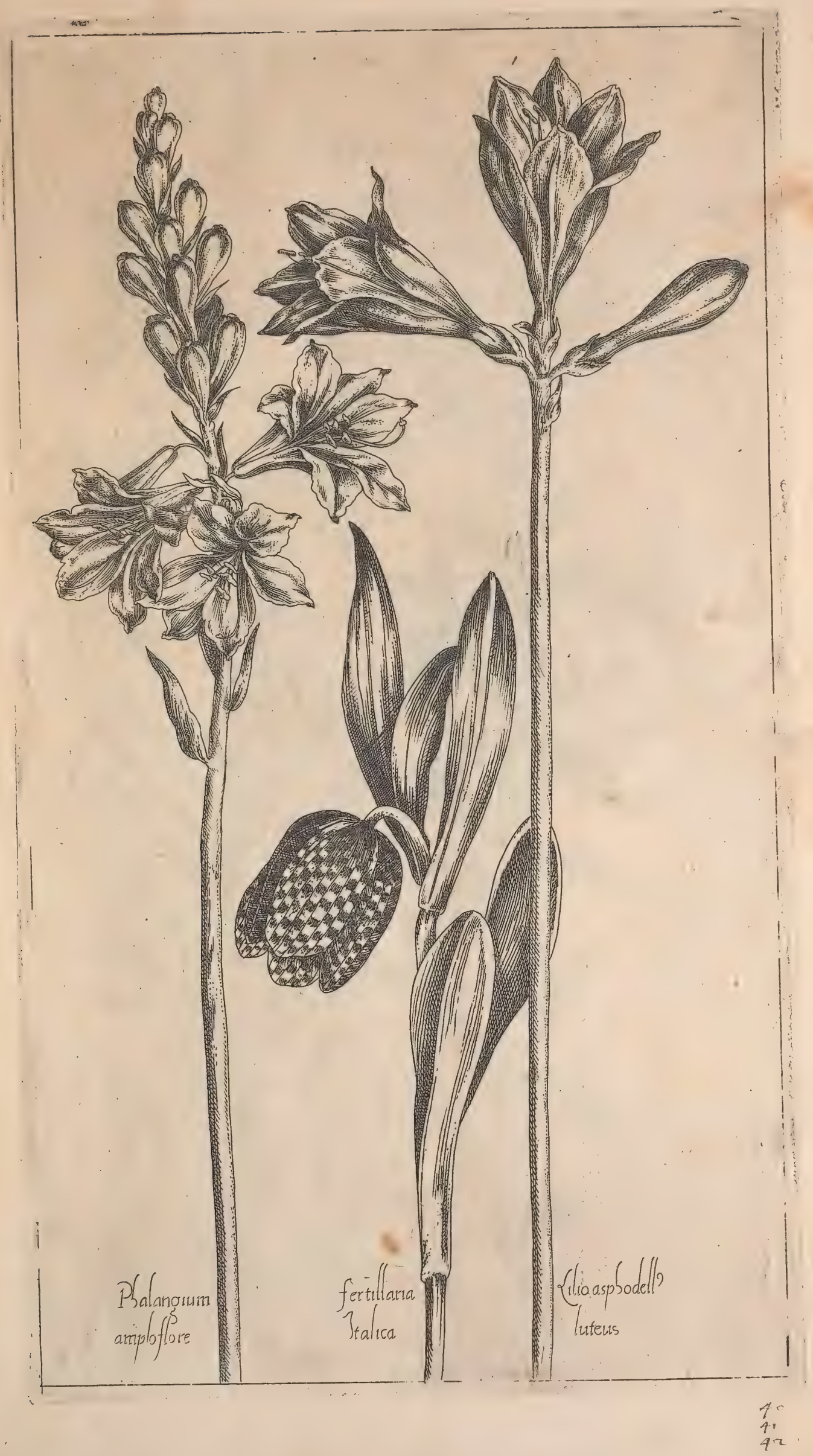


1

n

,
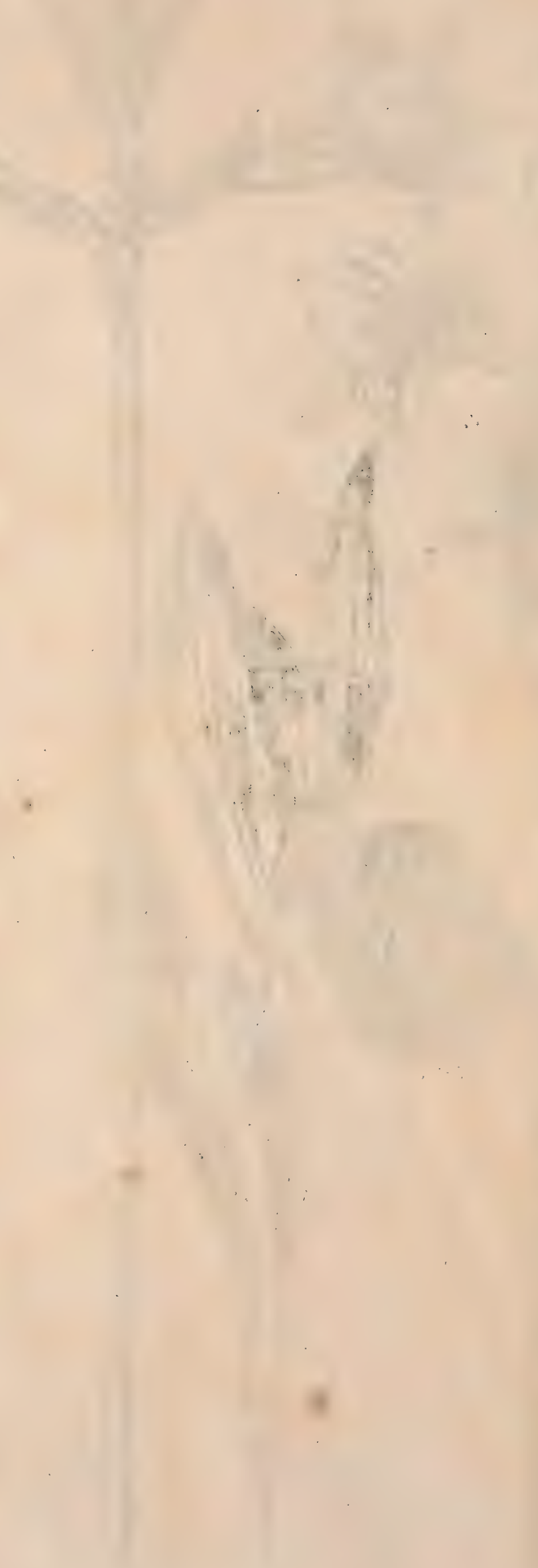


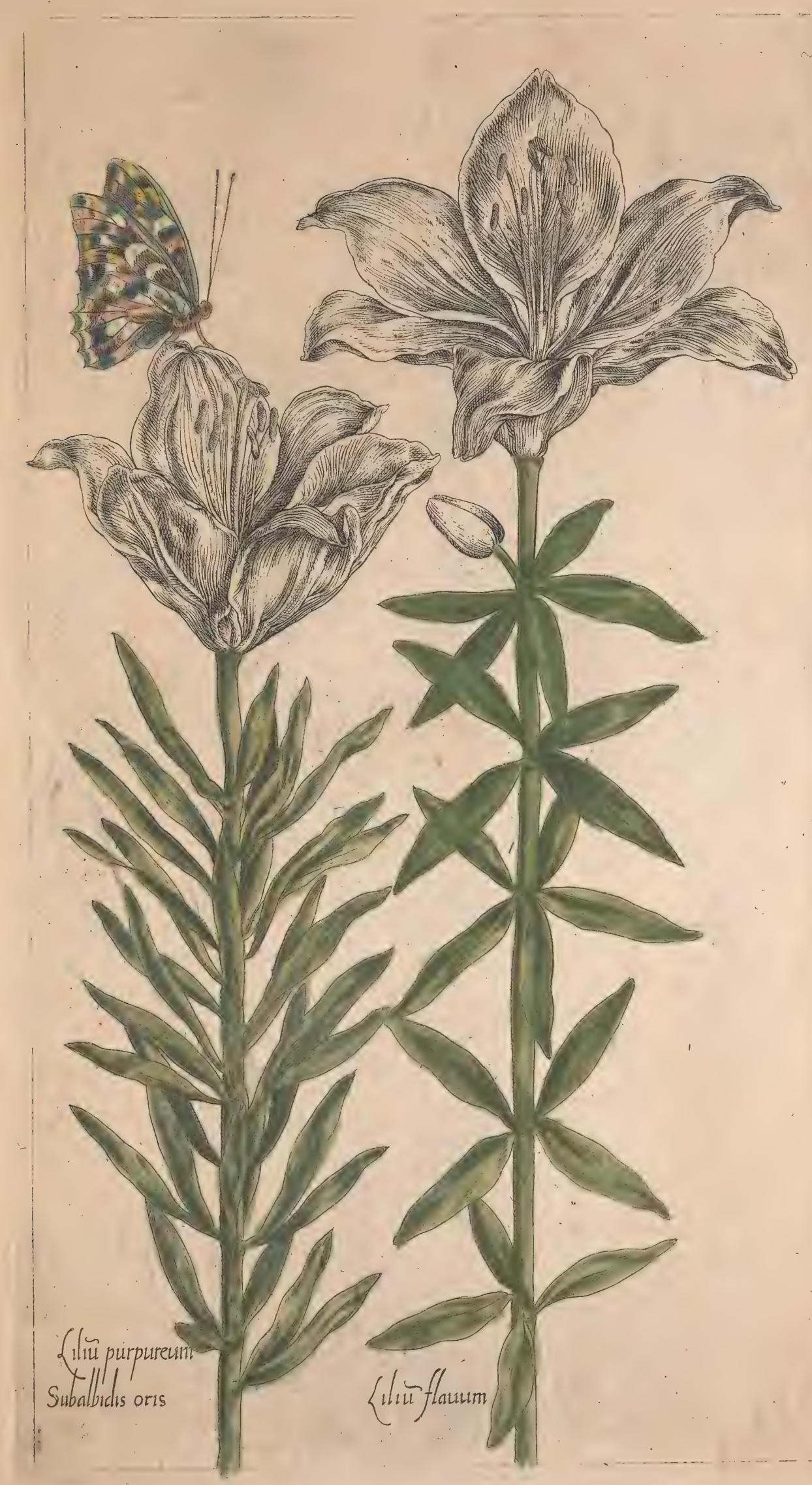

42 



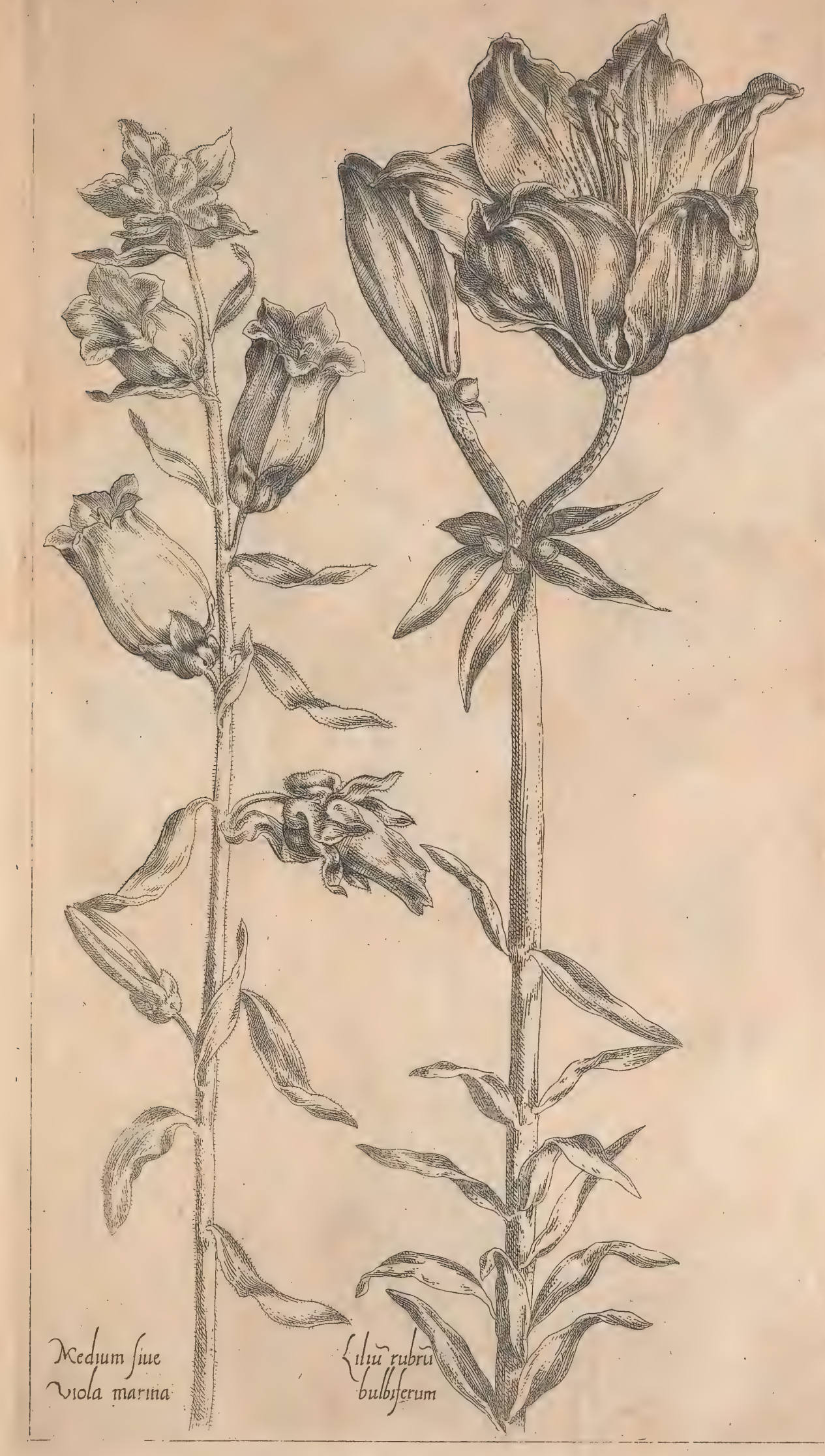





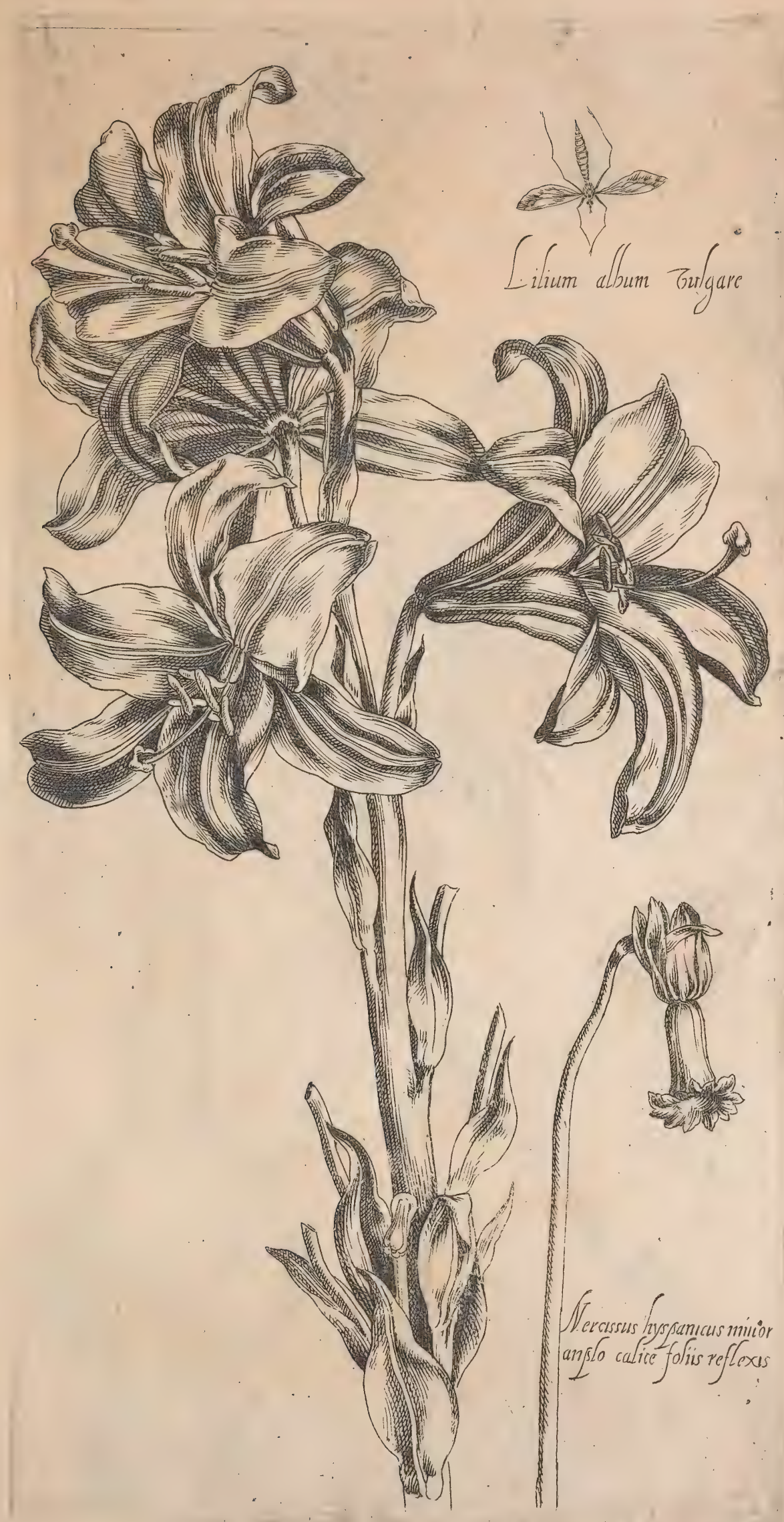




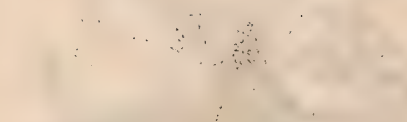

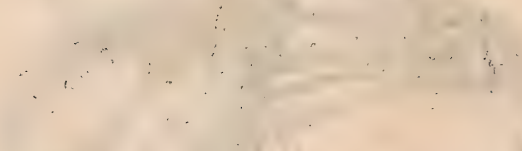

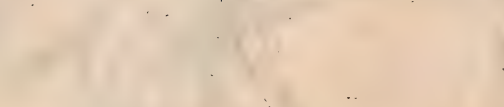

1

$\cdots$

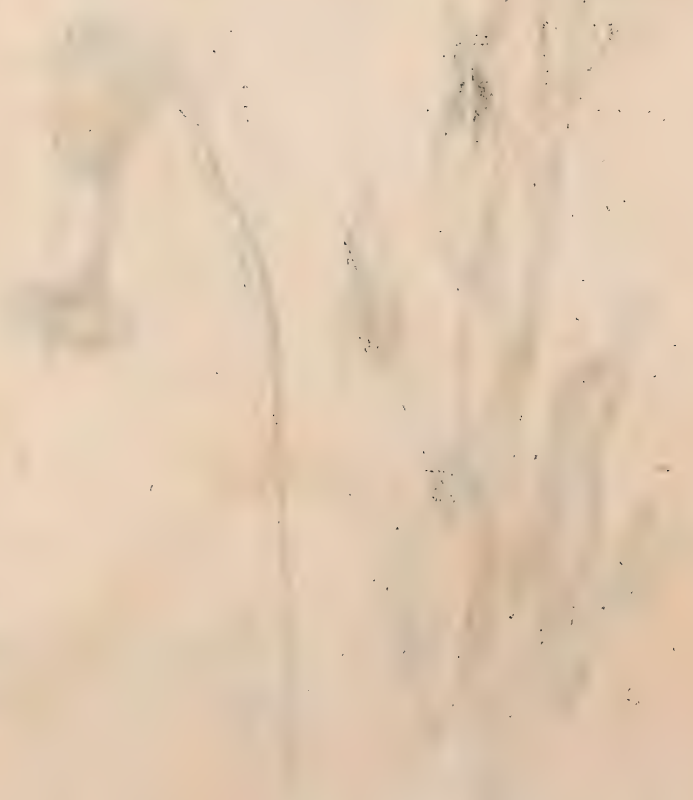




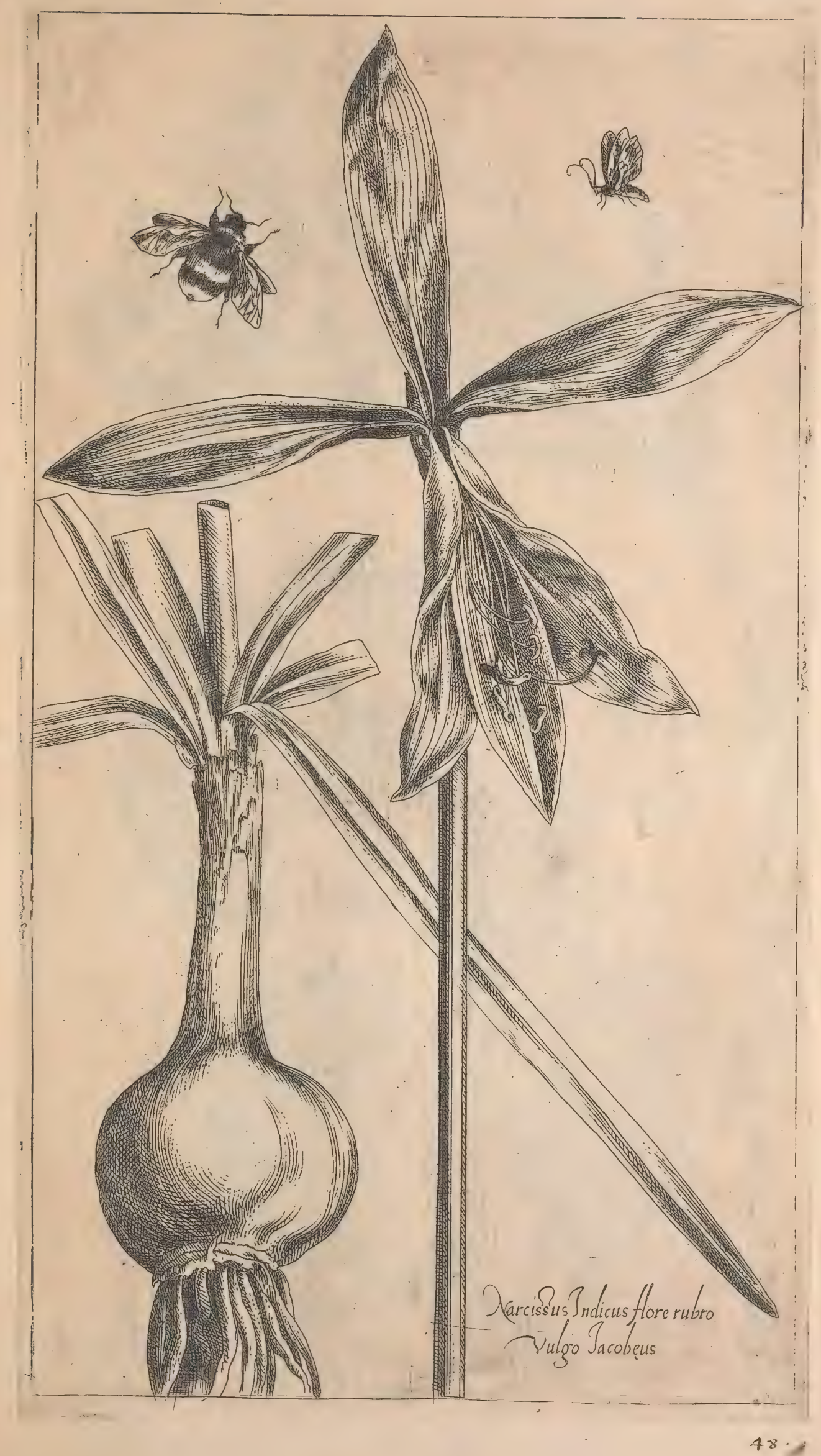





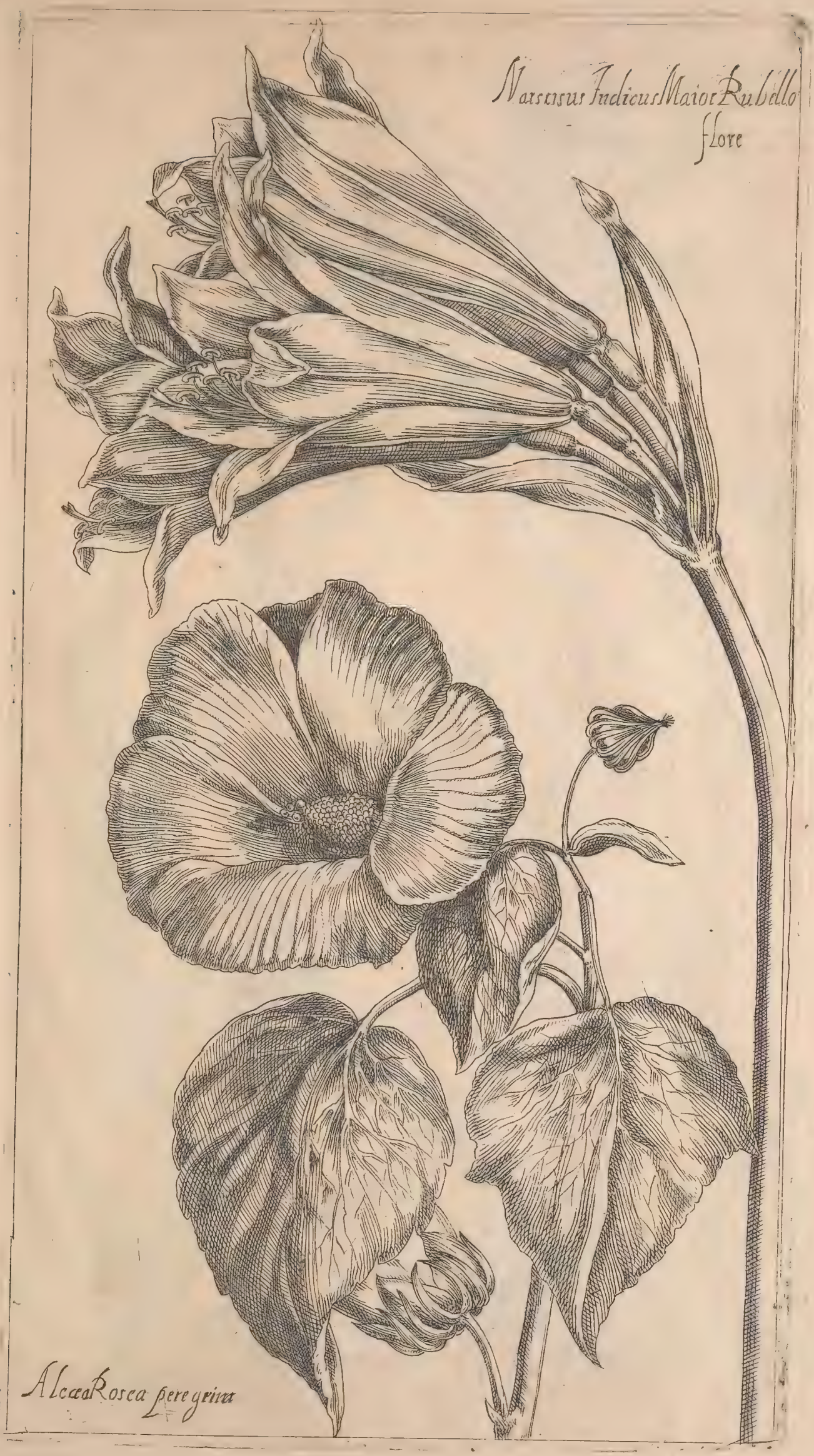





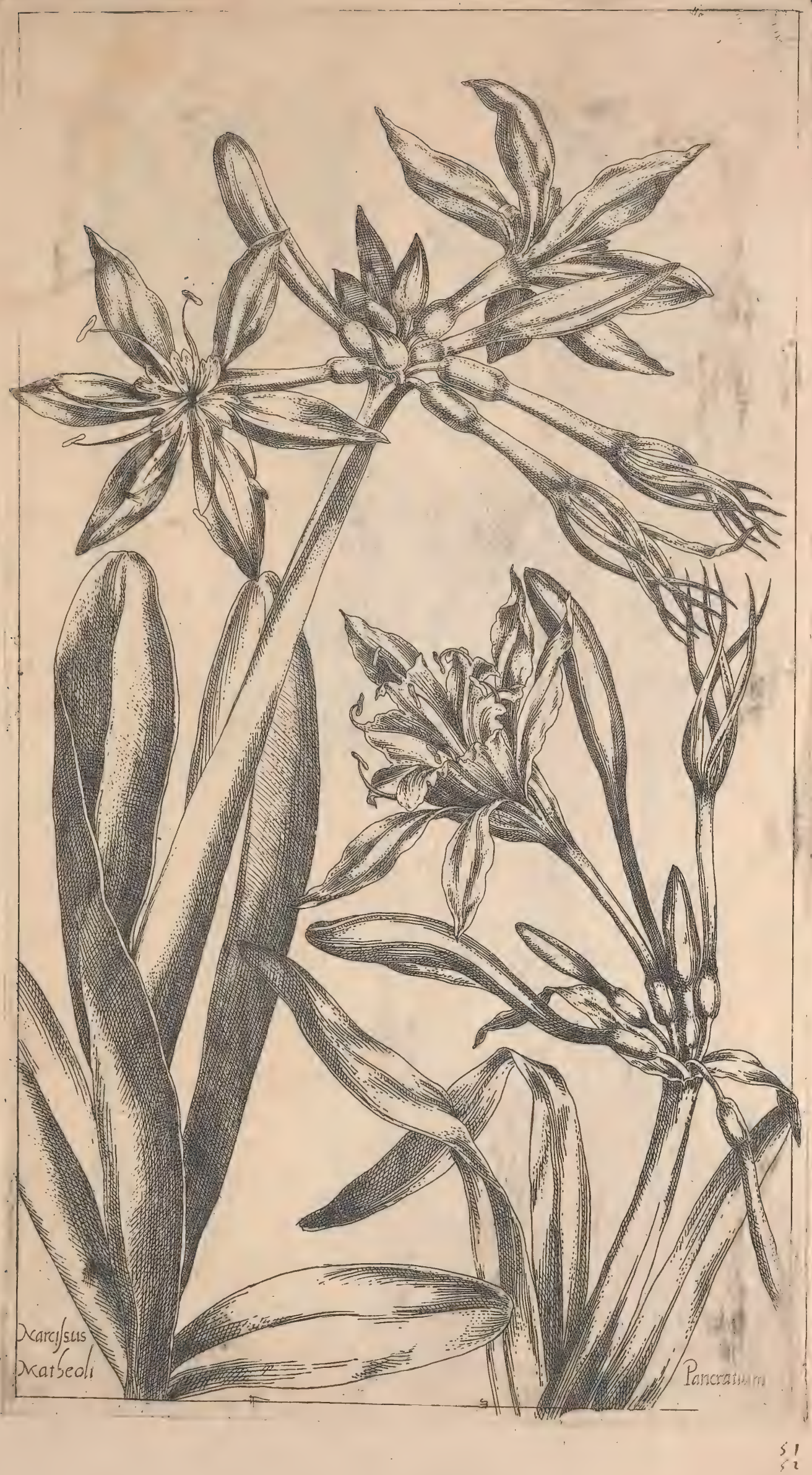





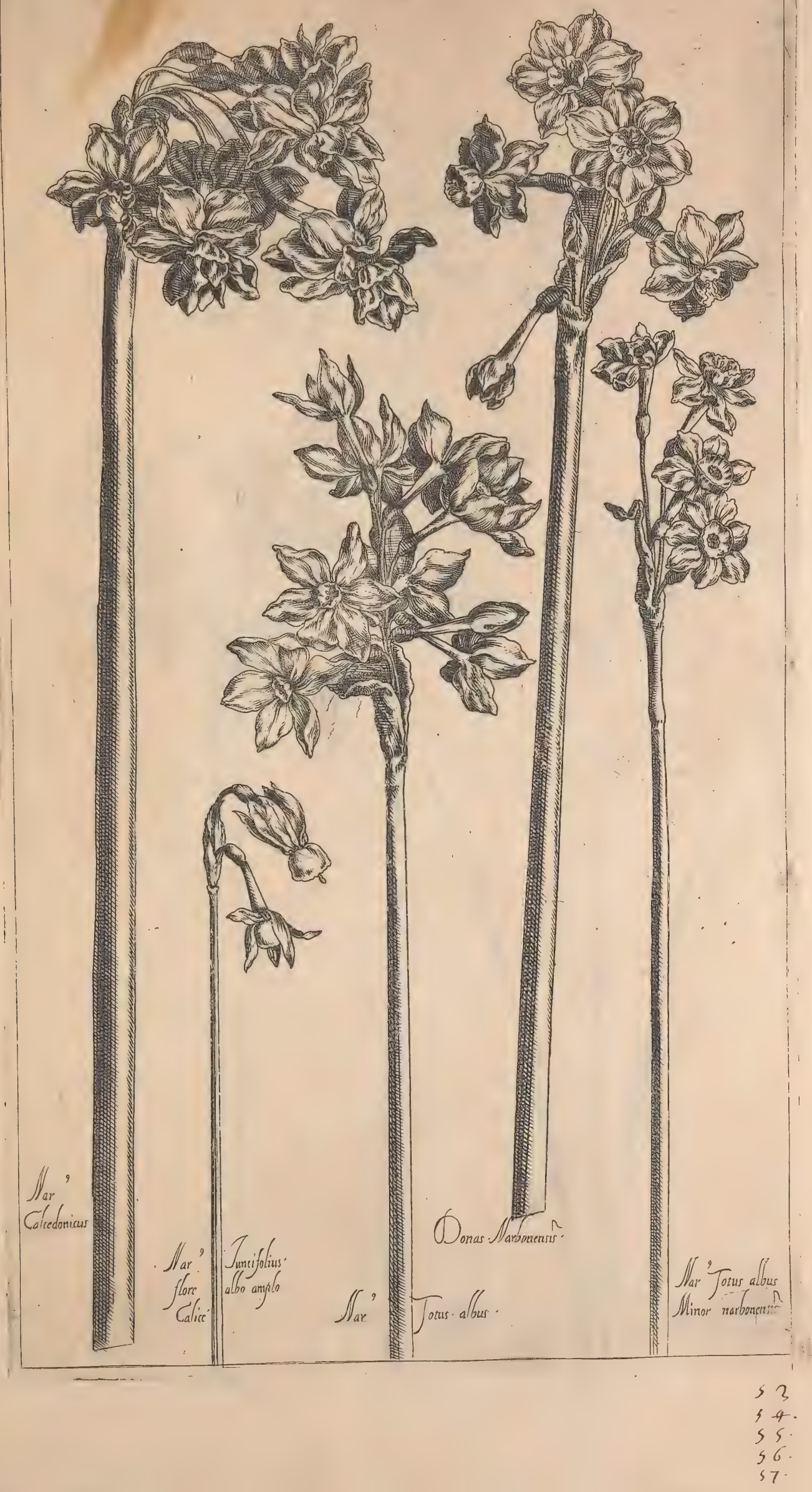





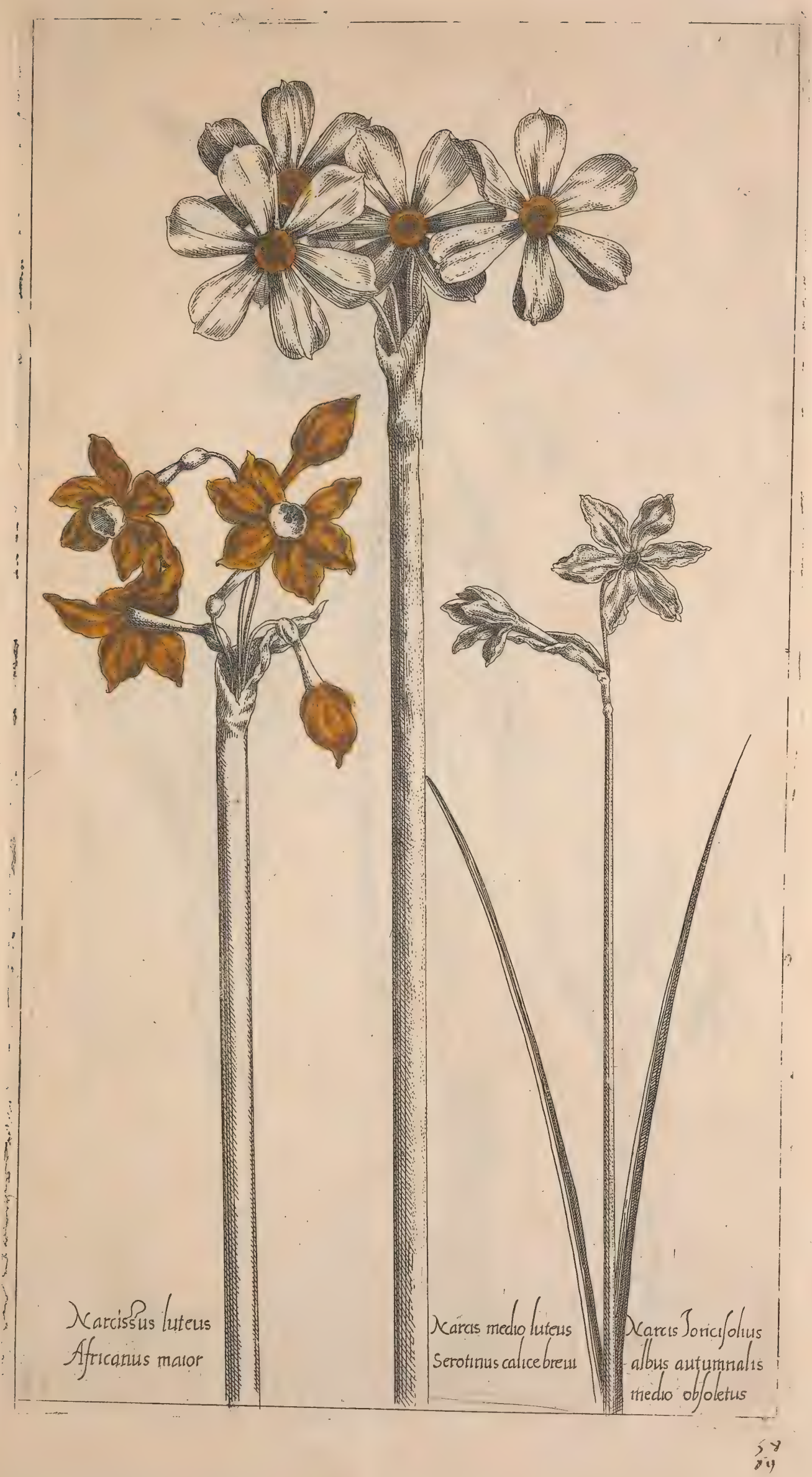




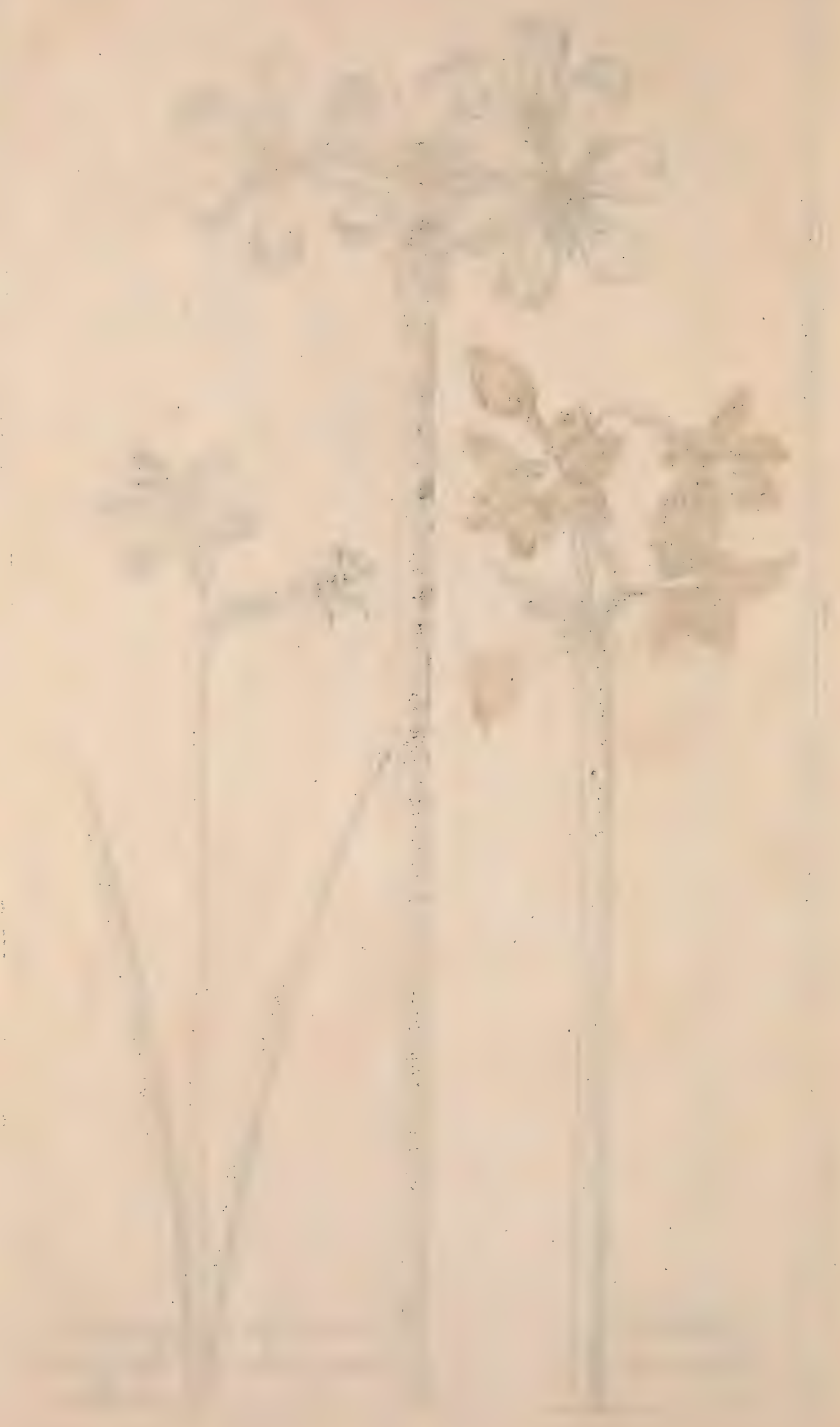




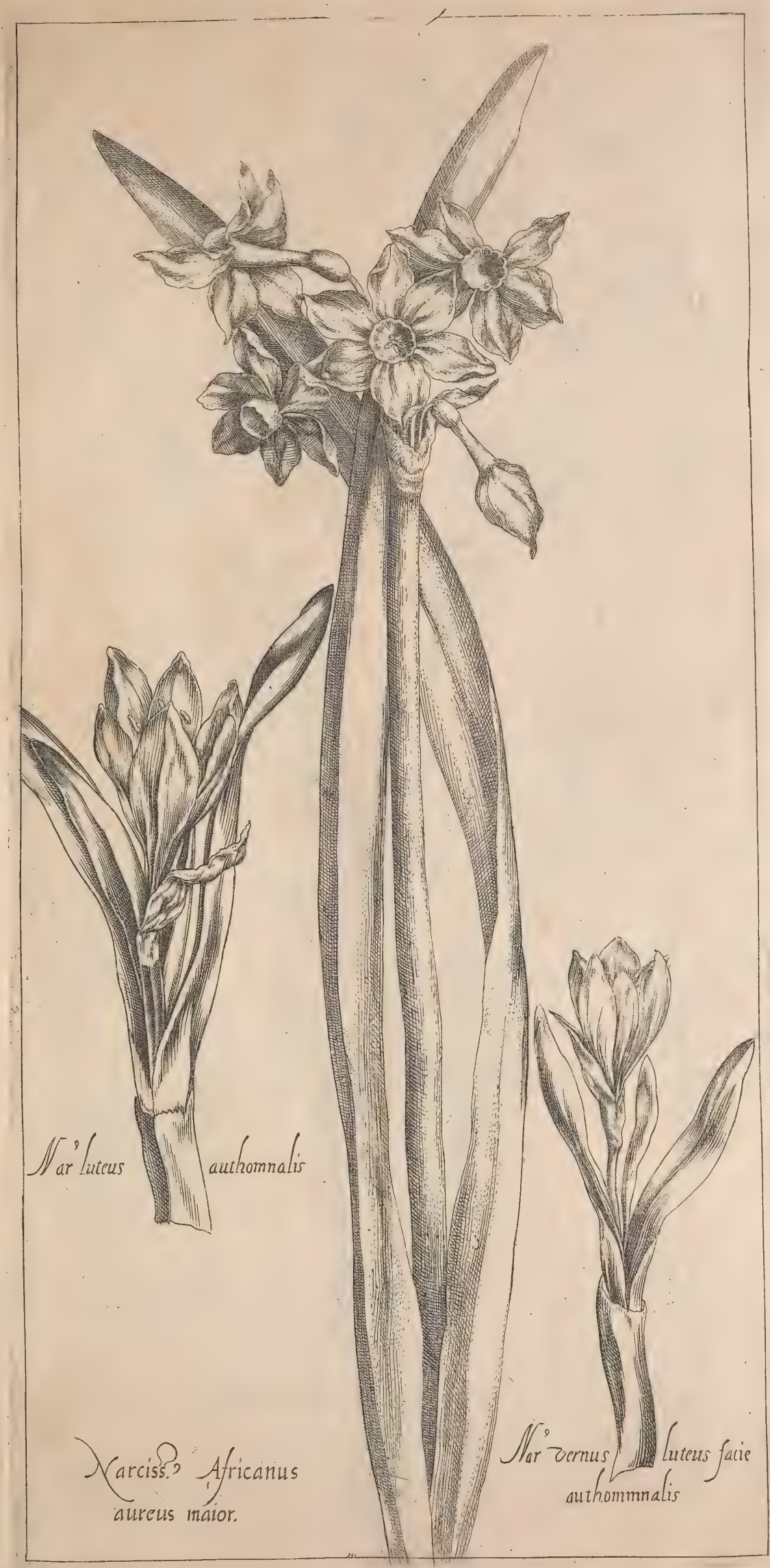





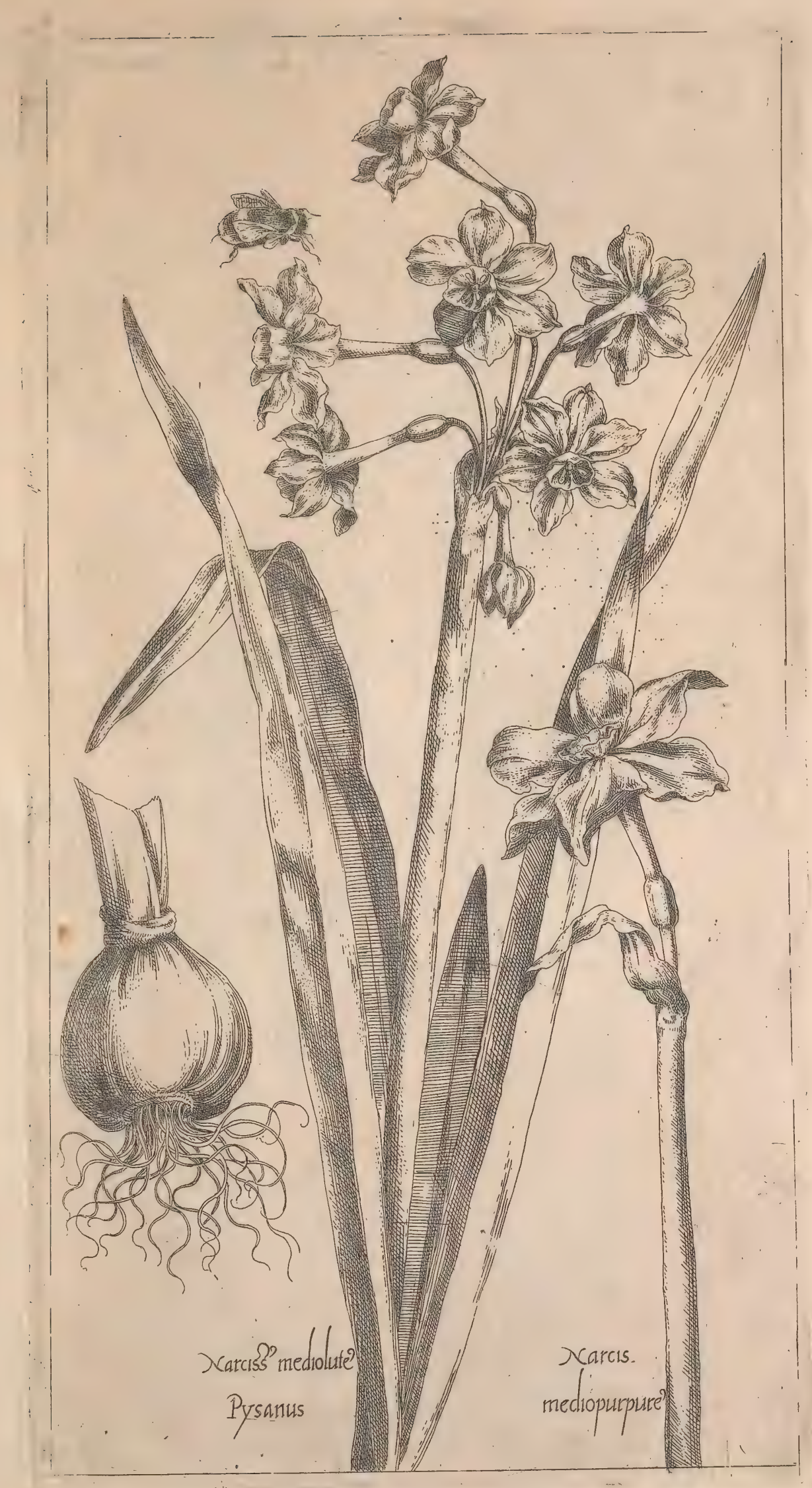




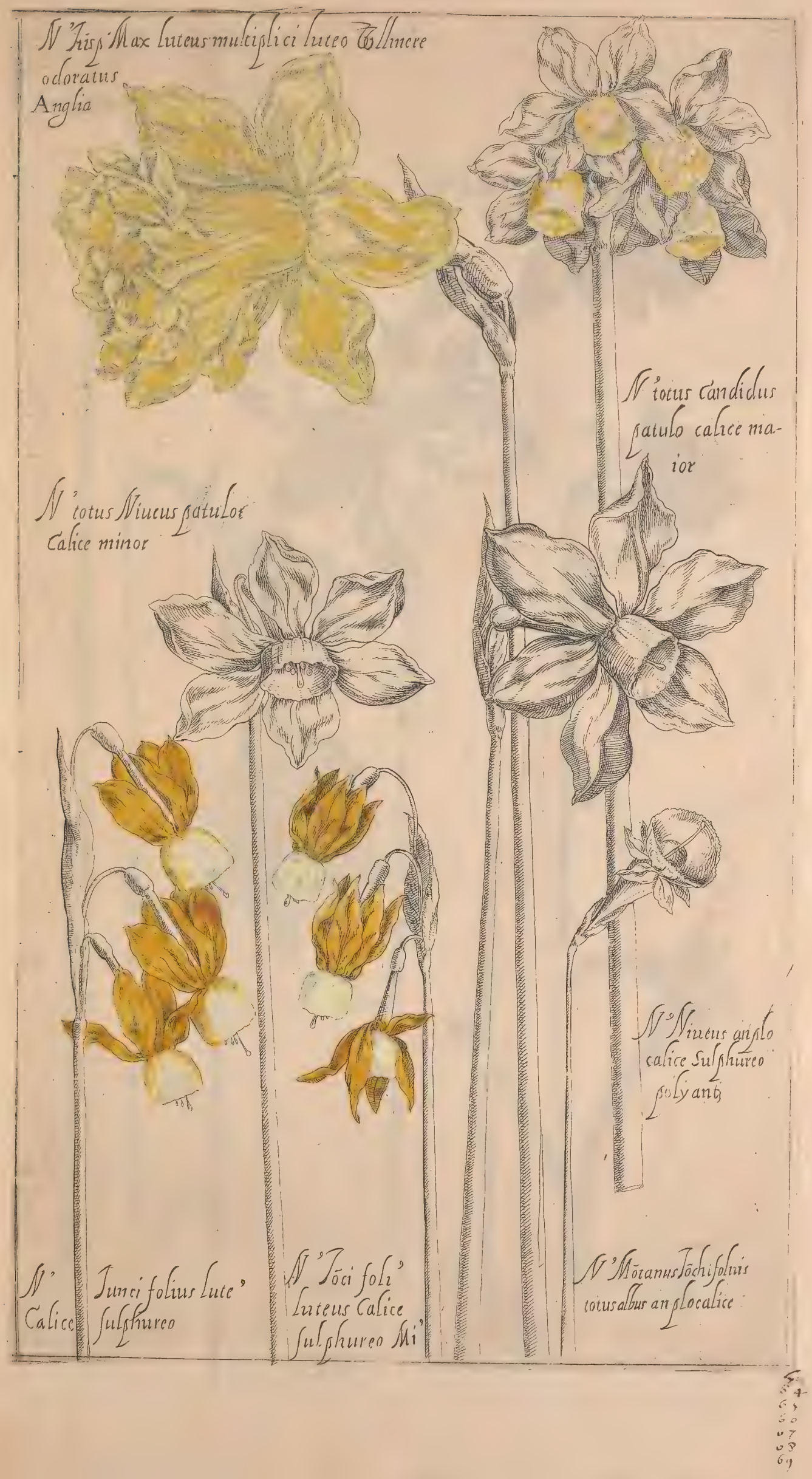




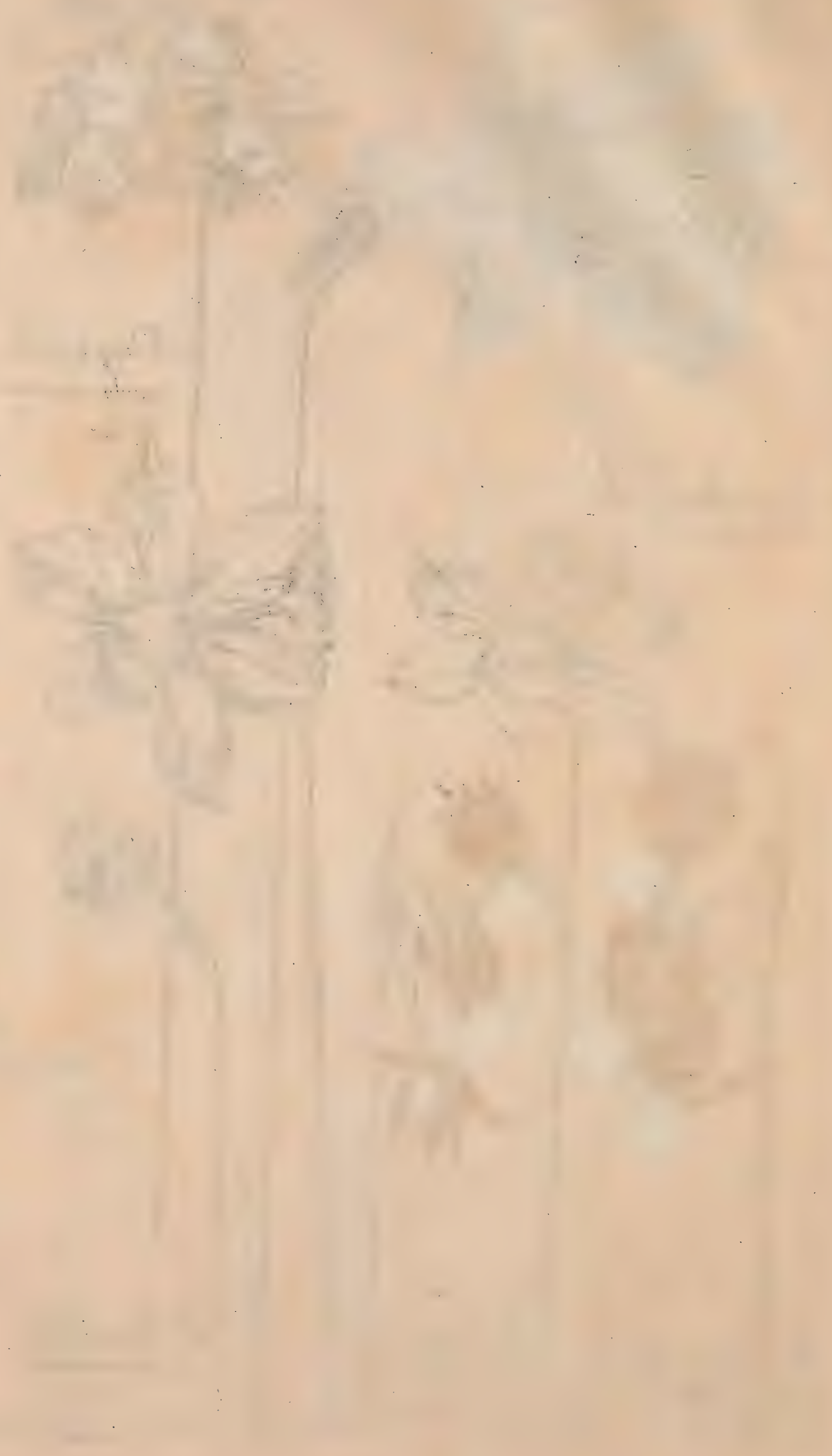




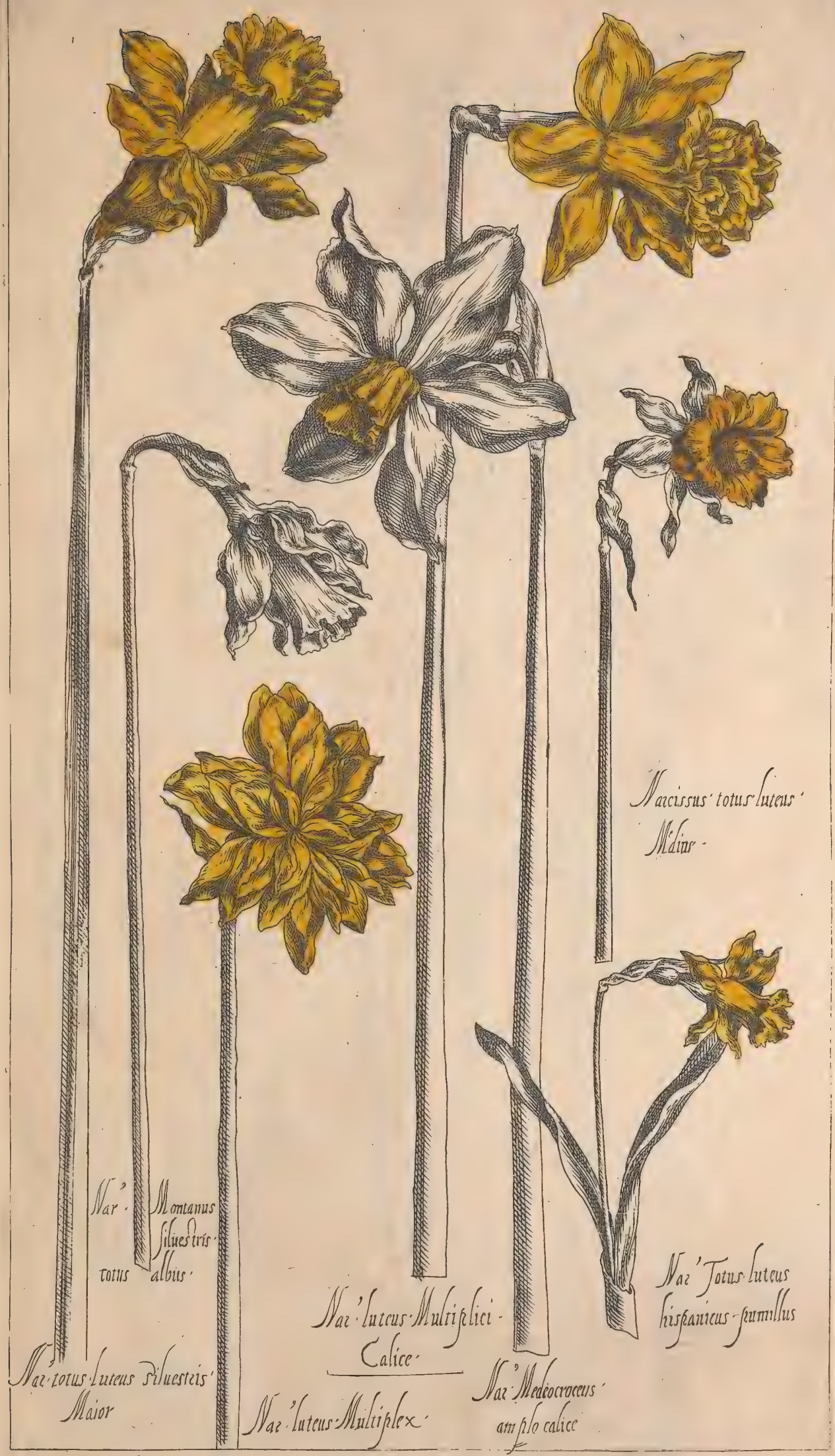





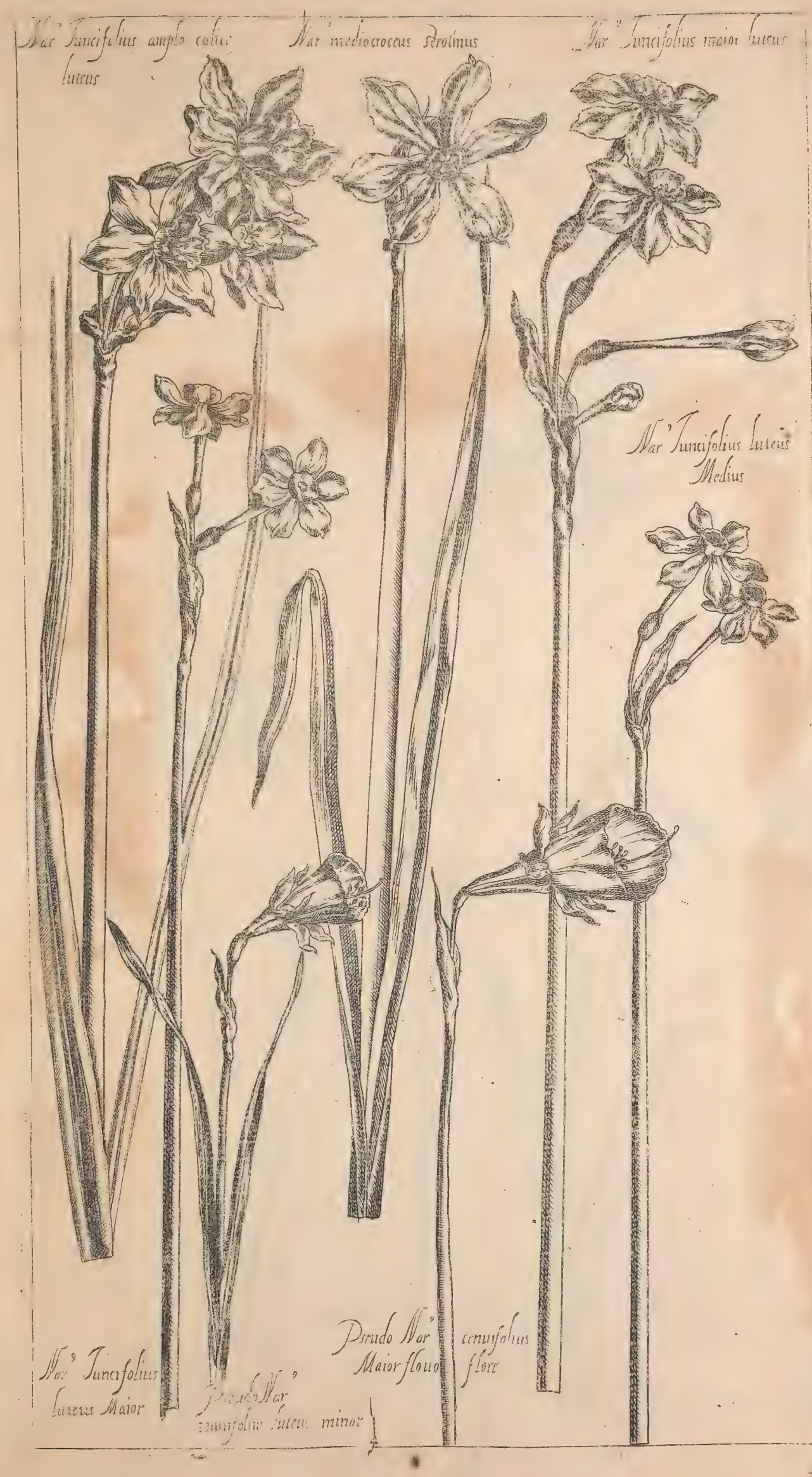




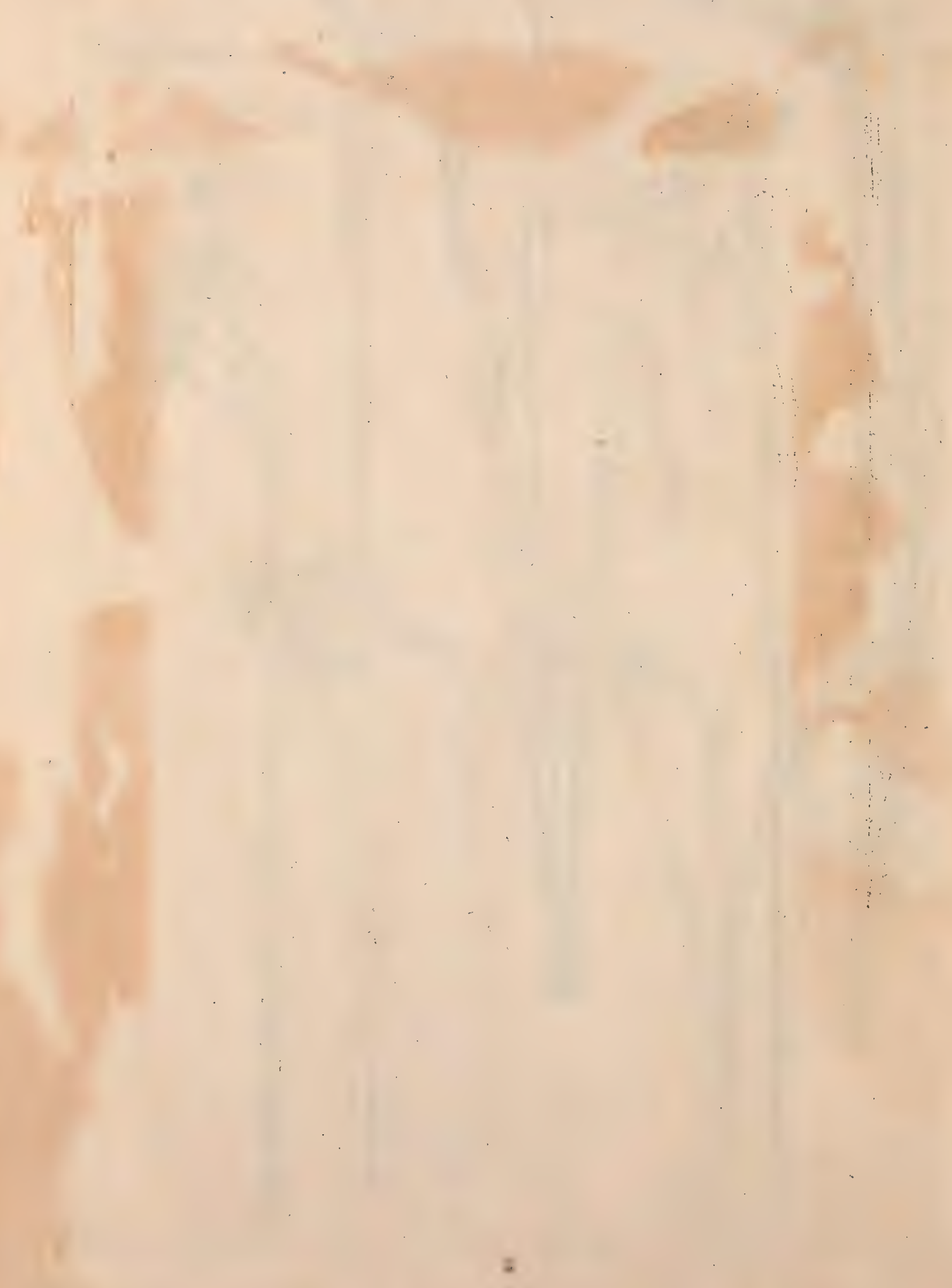




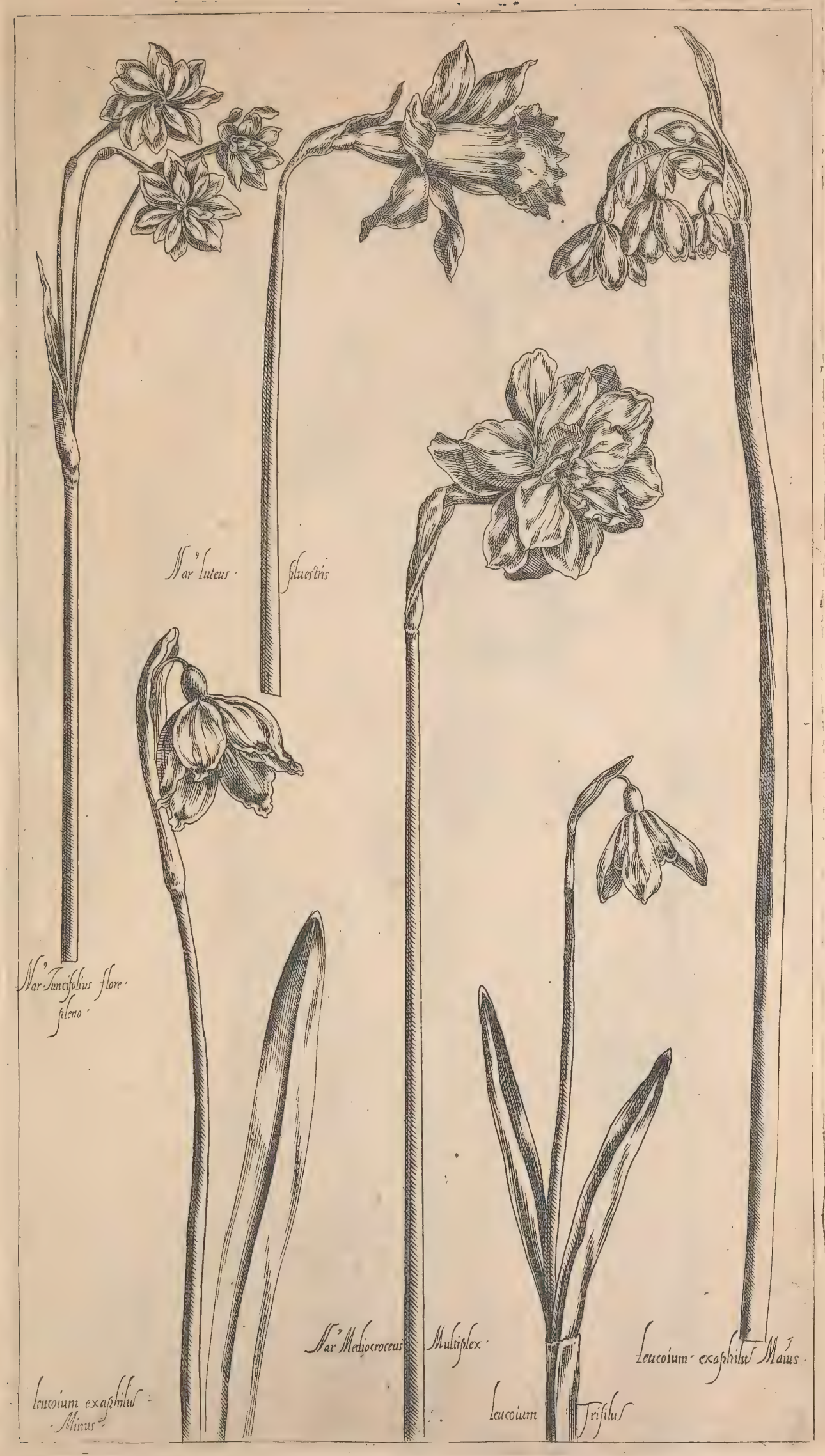





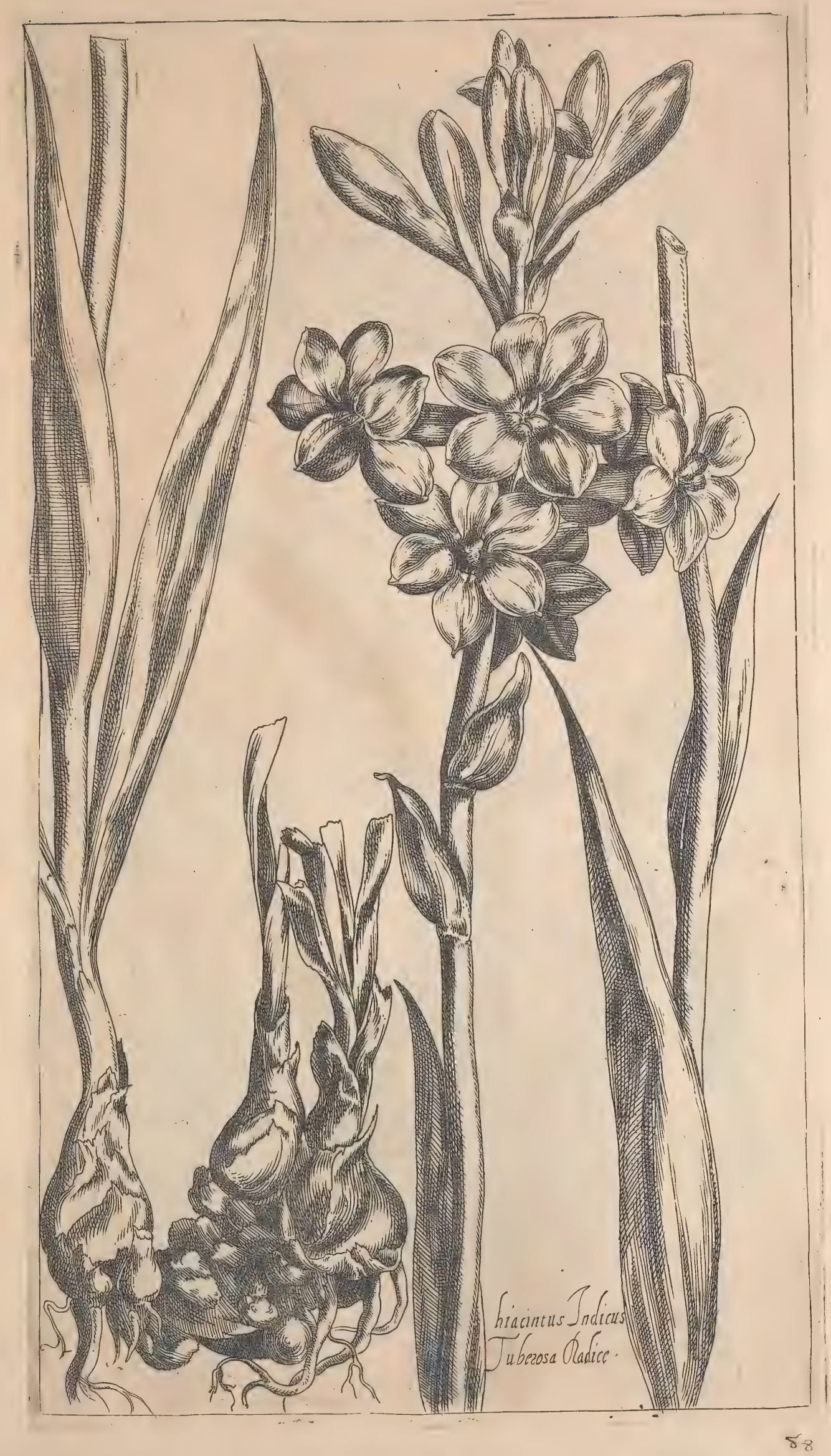





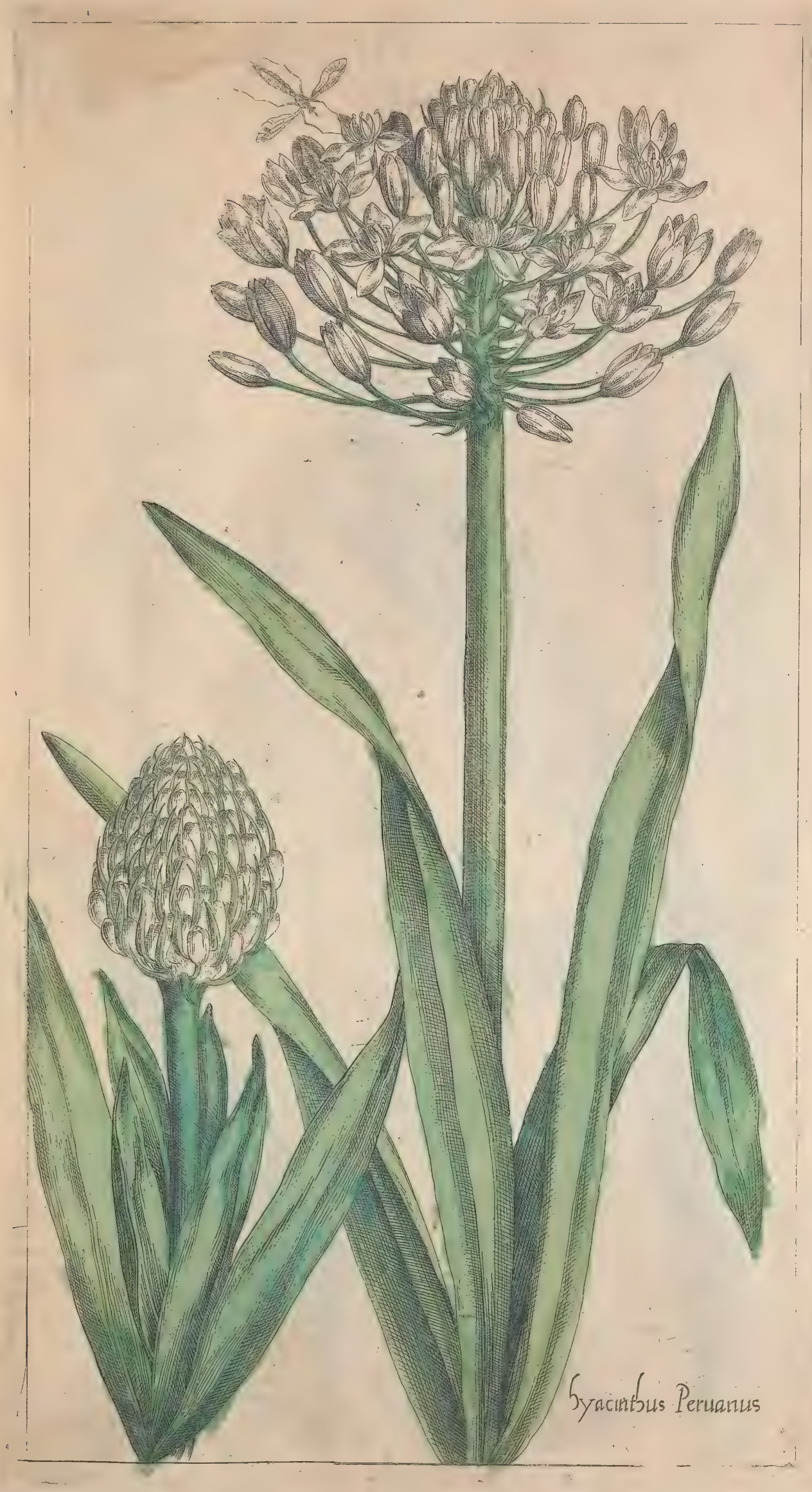





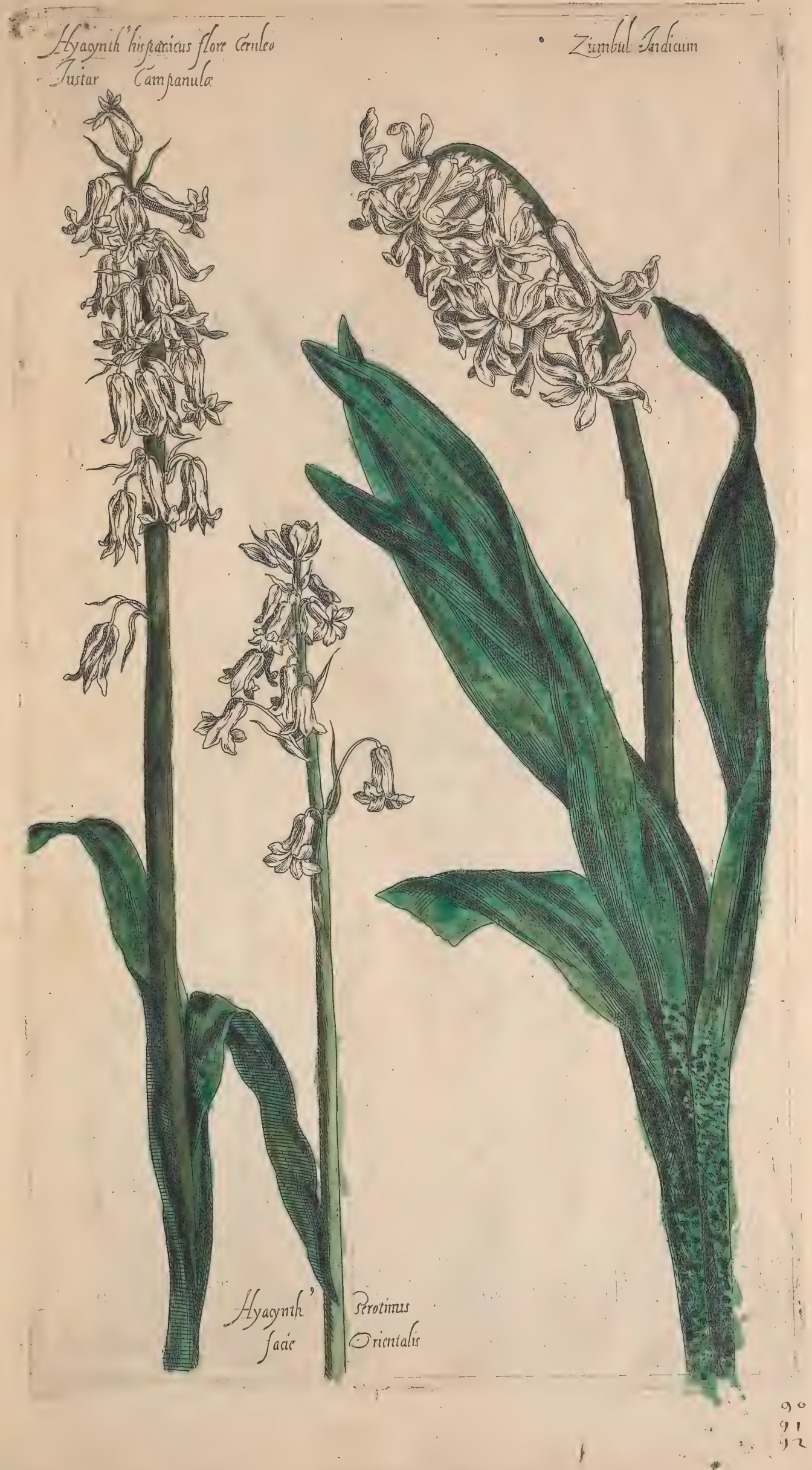





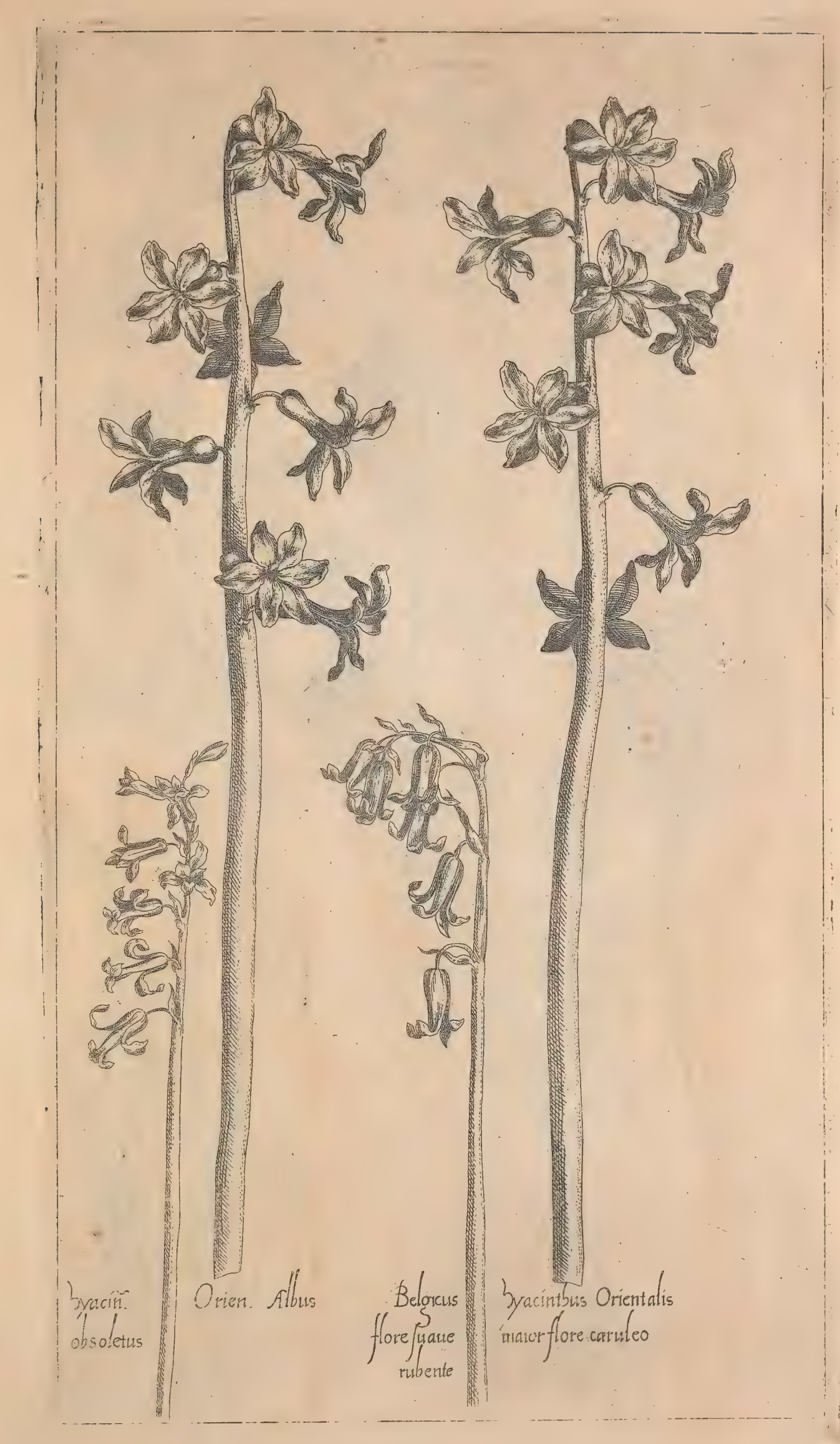





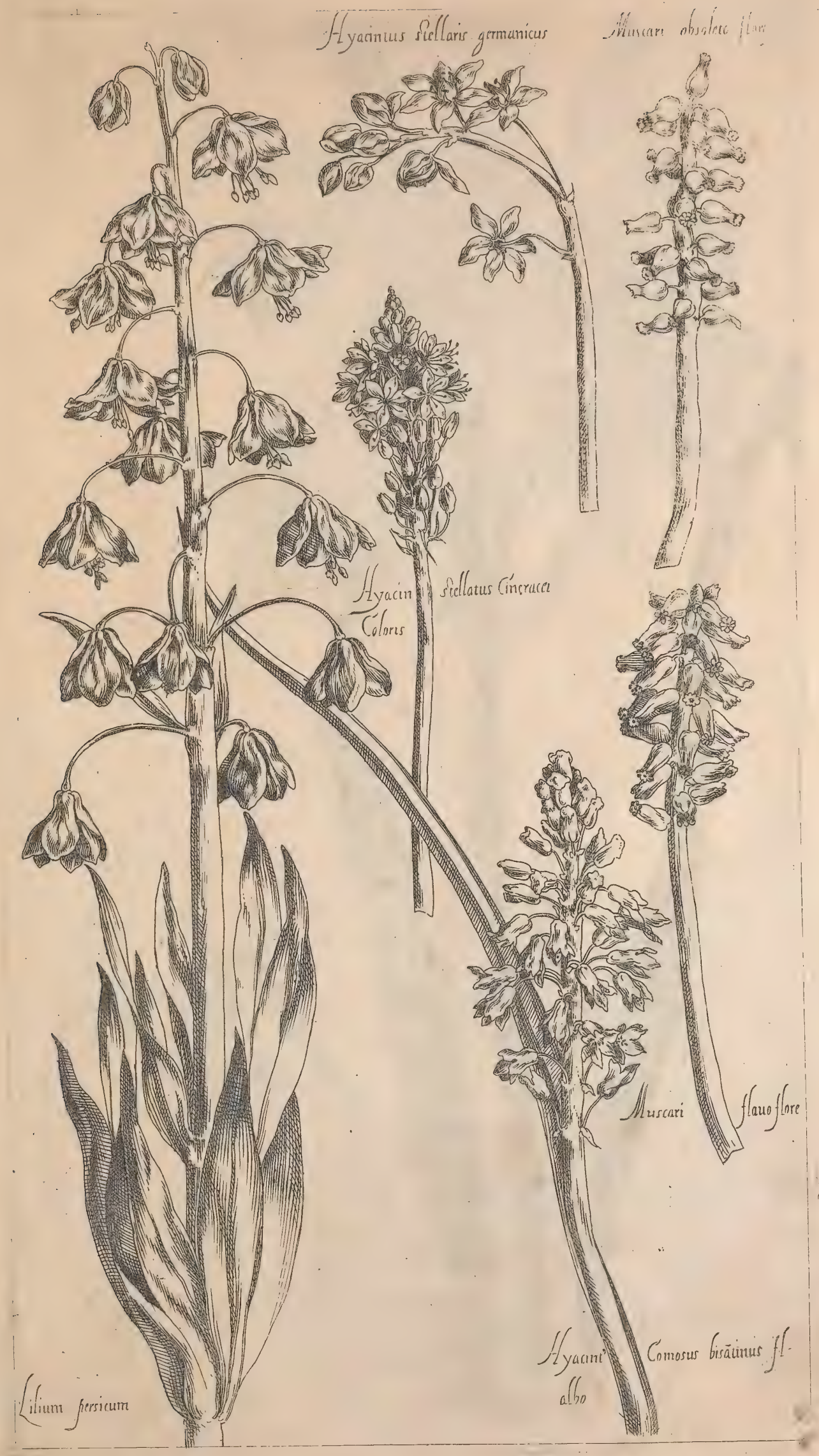





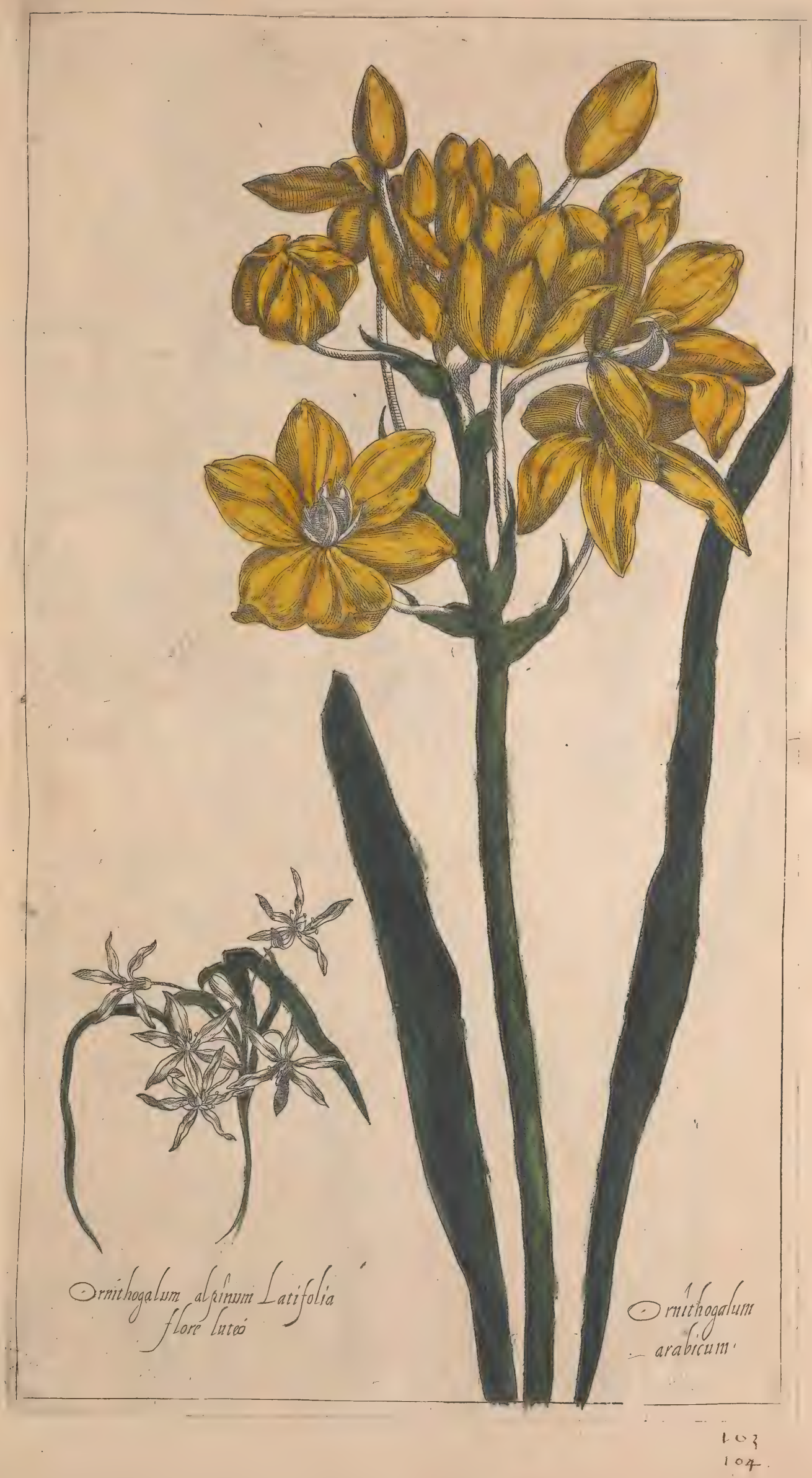



Srmithogalon Panonin flame flore Lacien
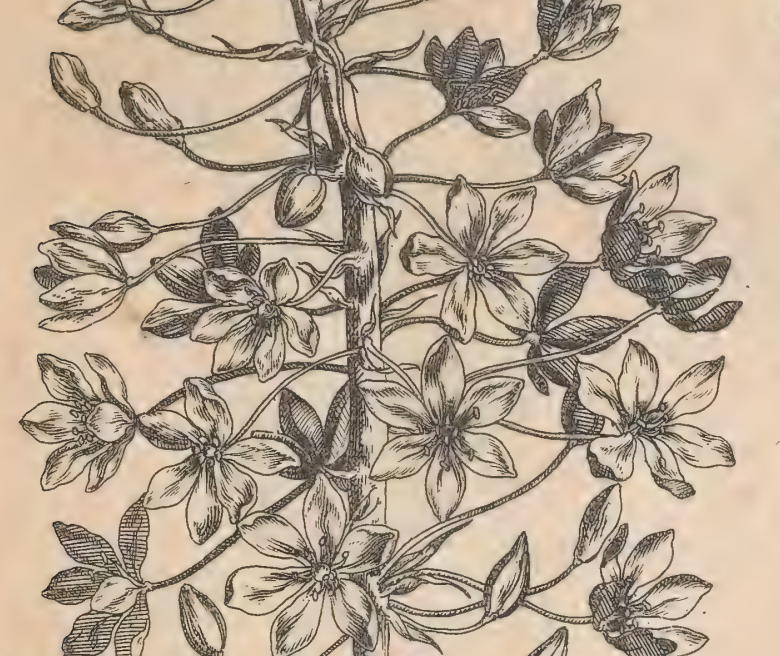

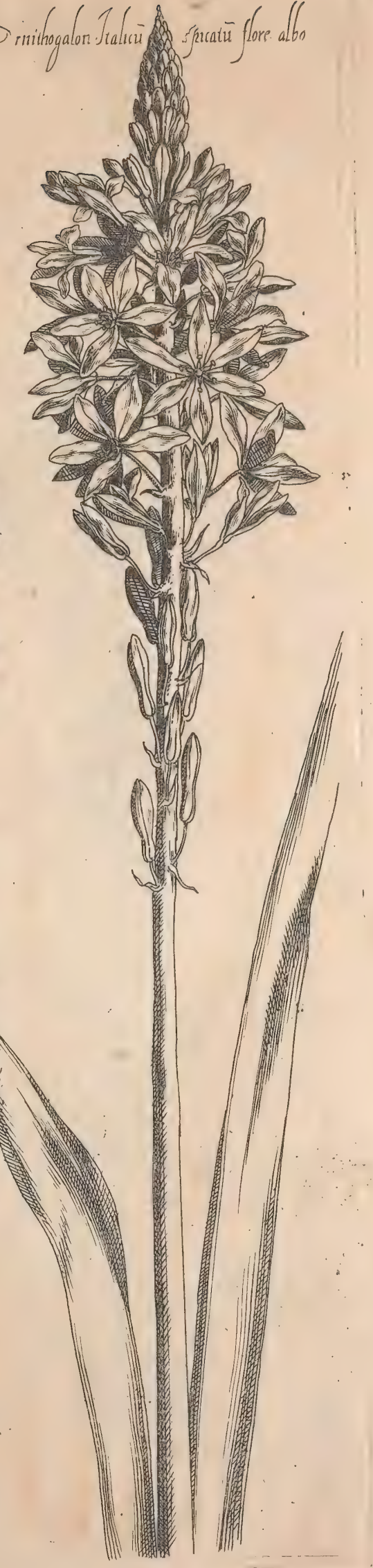





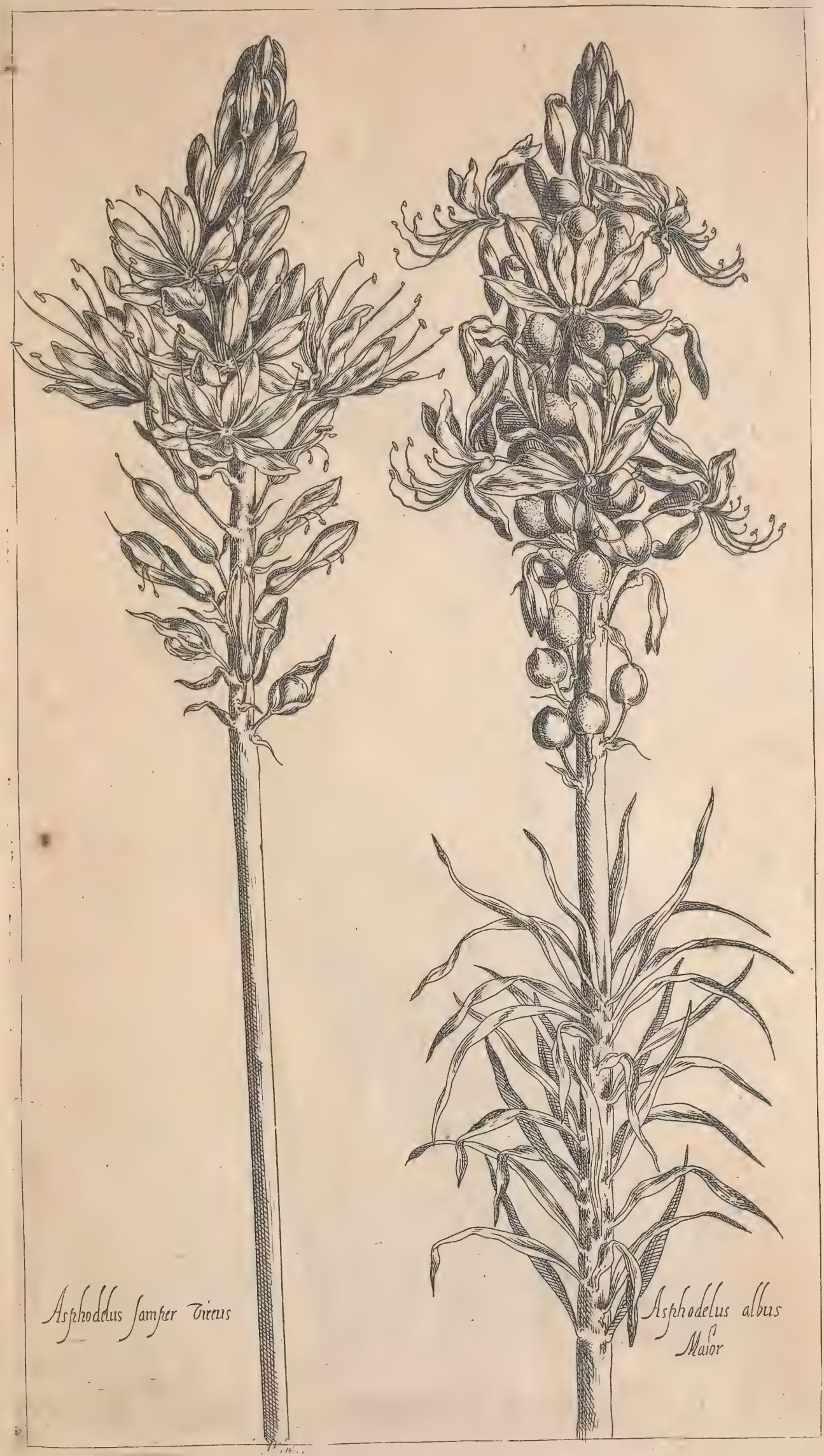





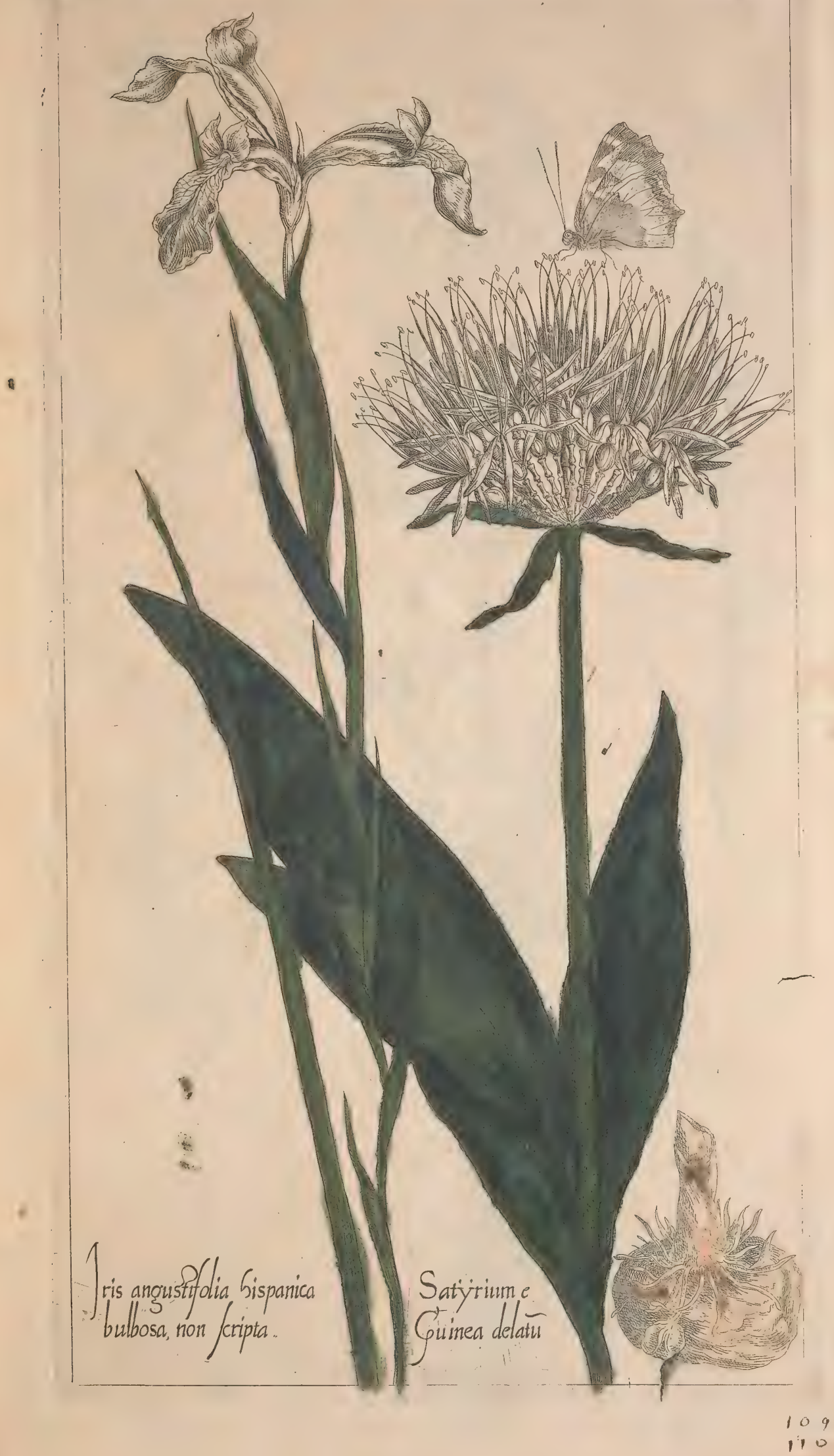





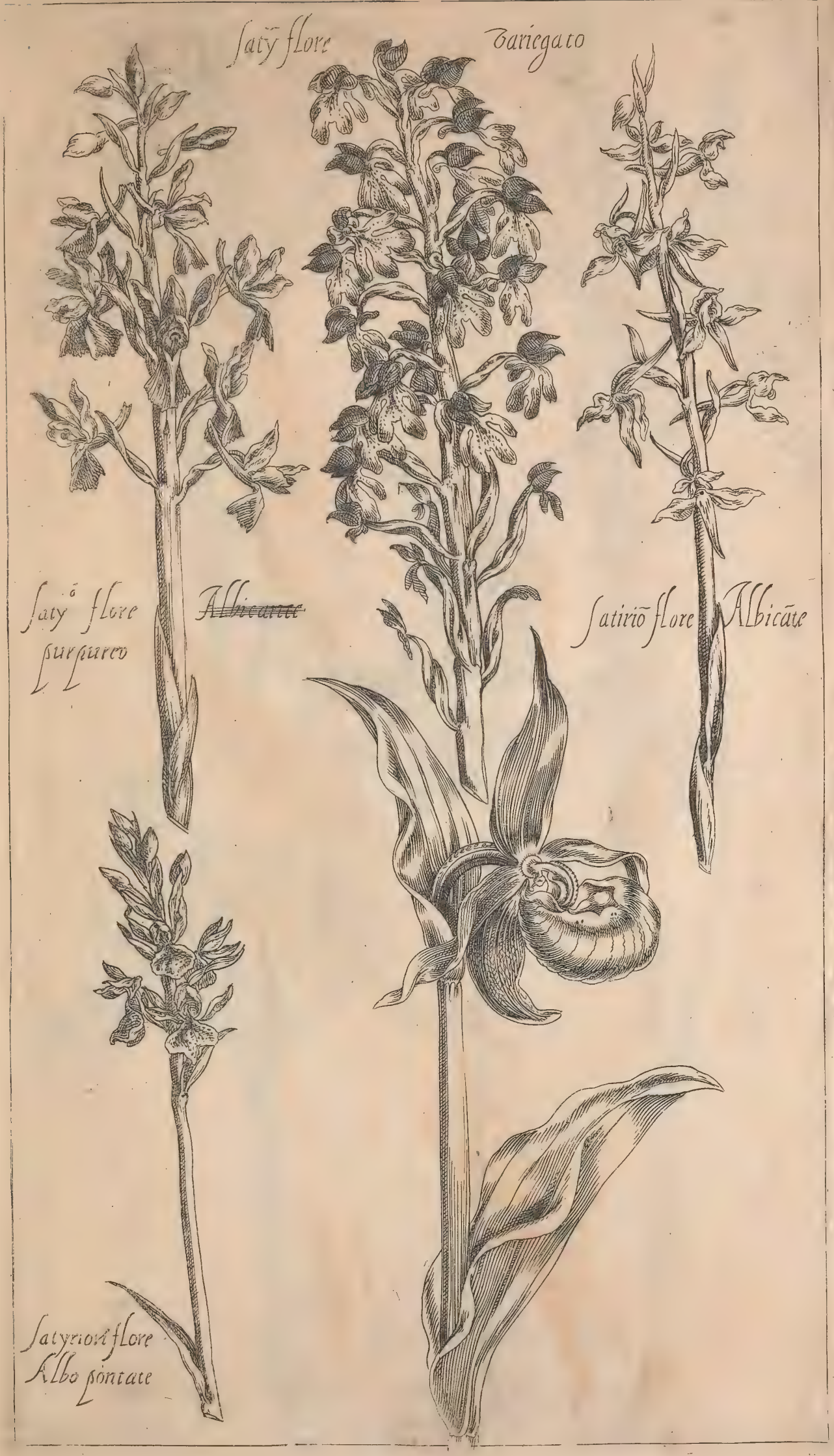





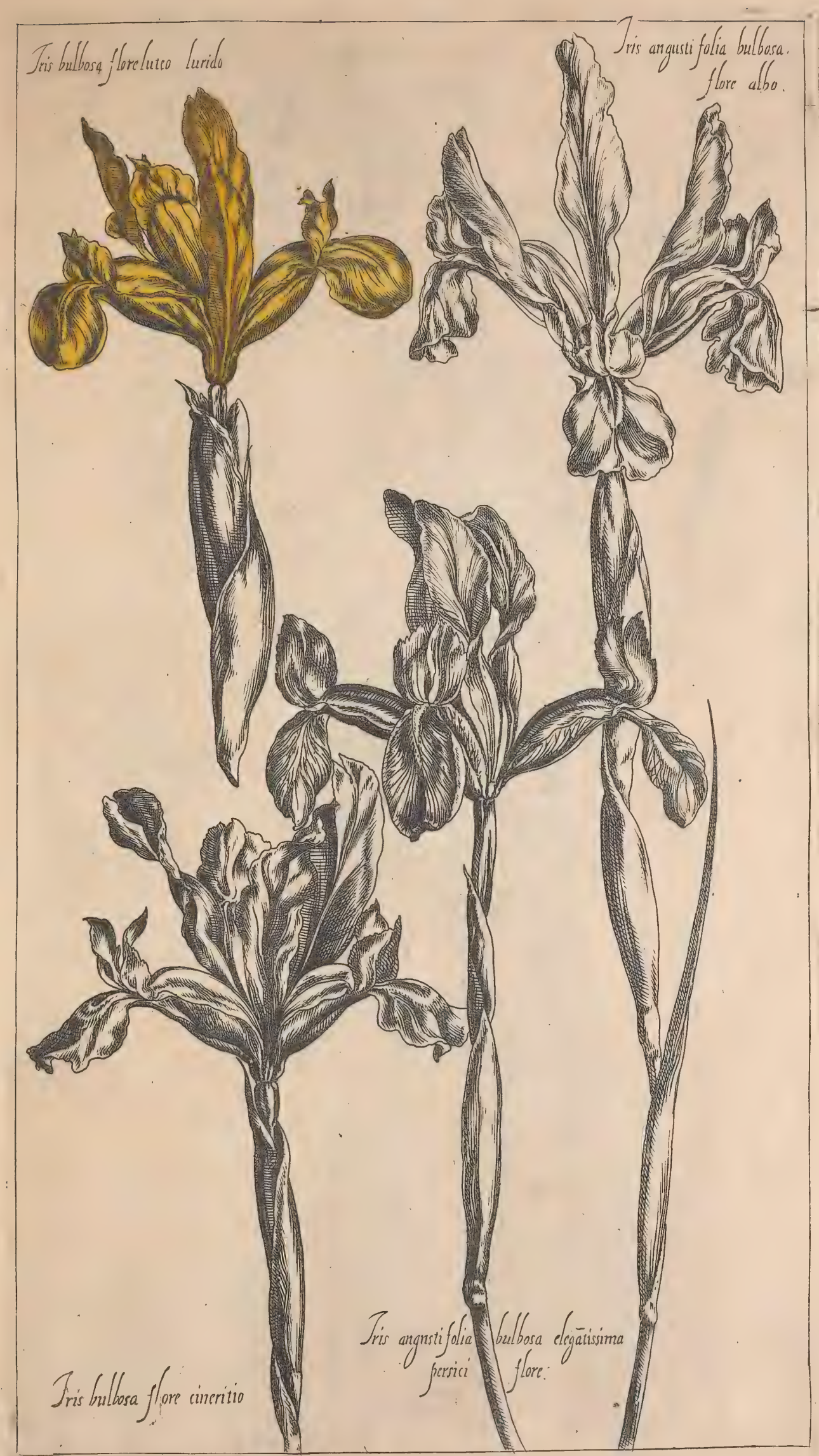





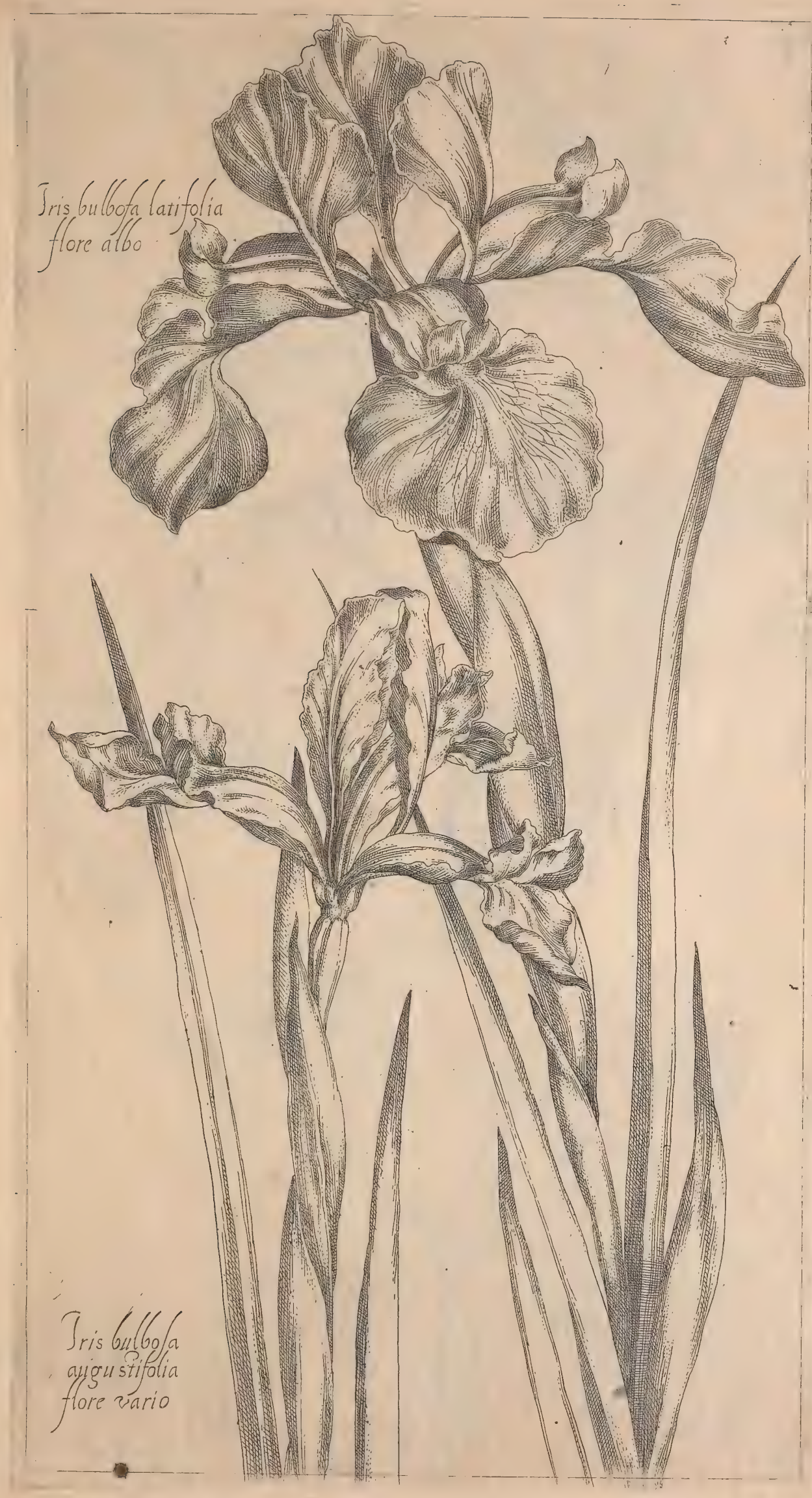





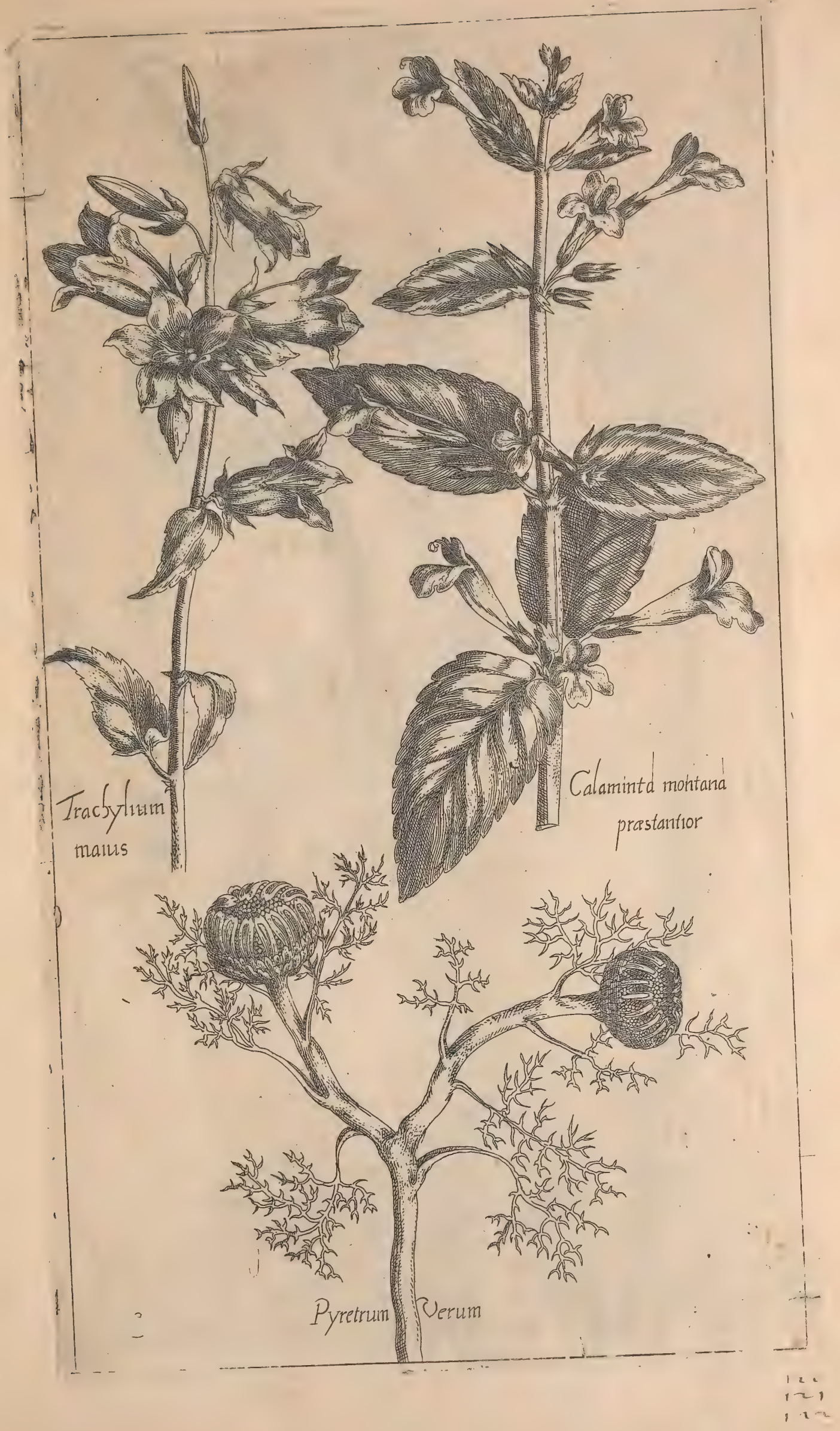





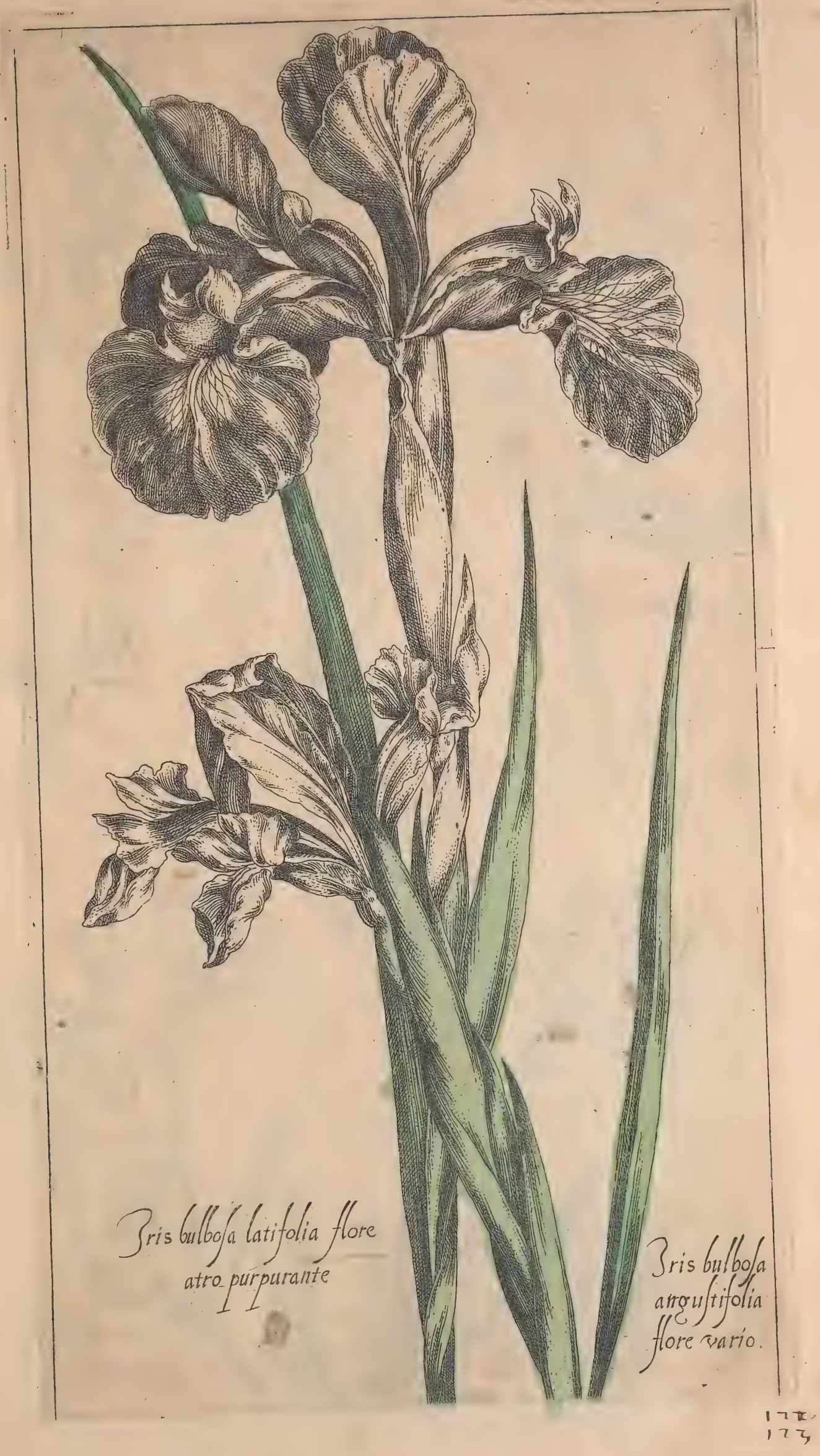



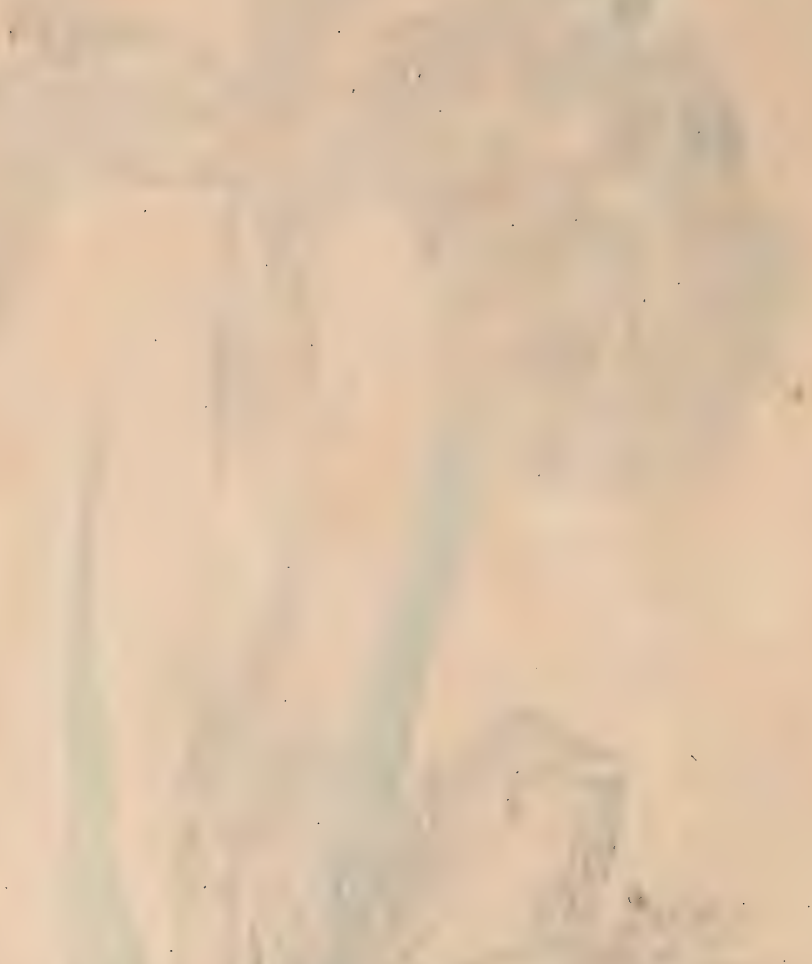

$$
\text { . }
$$



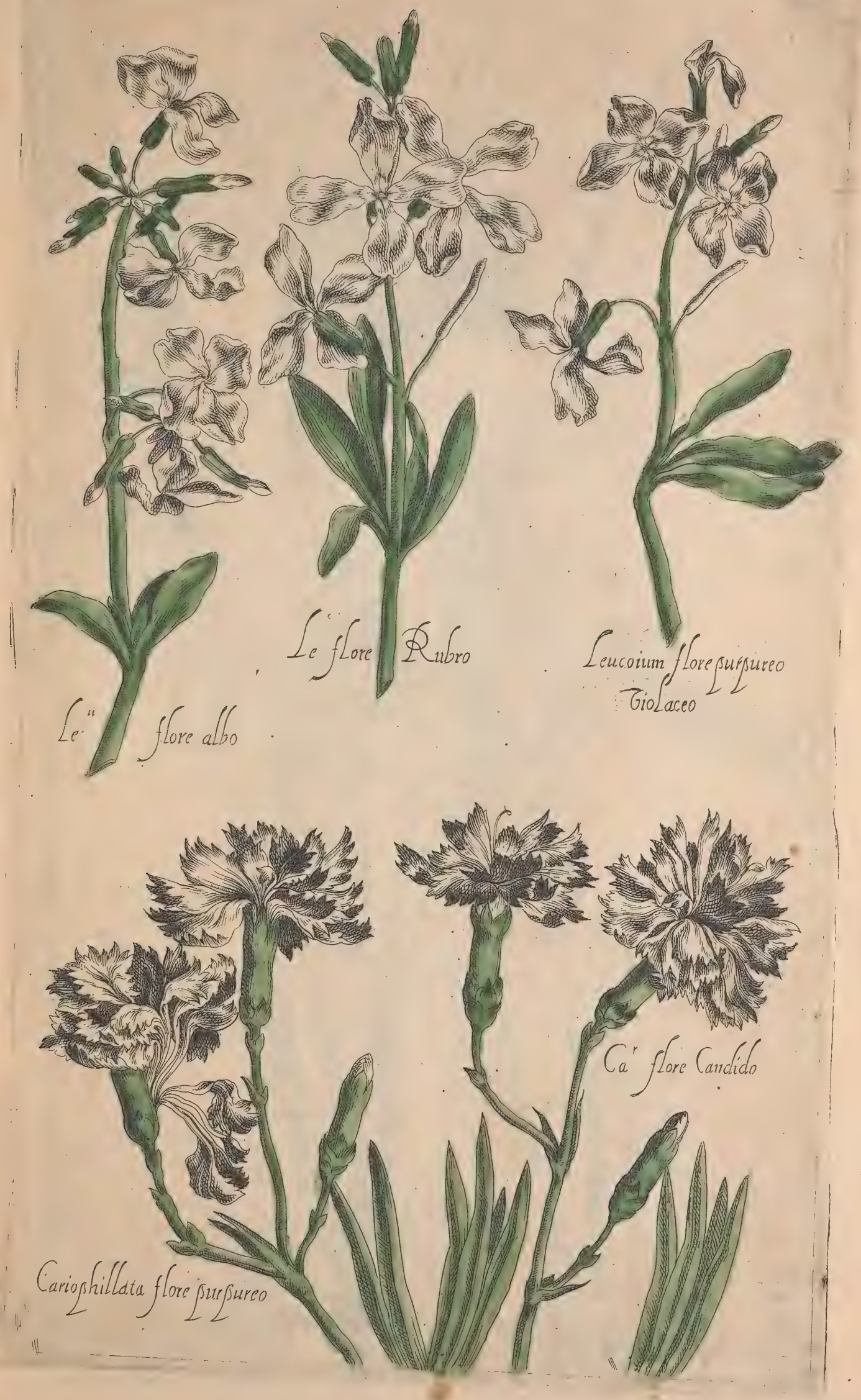

$$
\begin{aligned}
& 123 \\
& 127 . \\
& 121 .
\end{aligned}
$$


.

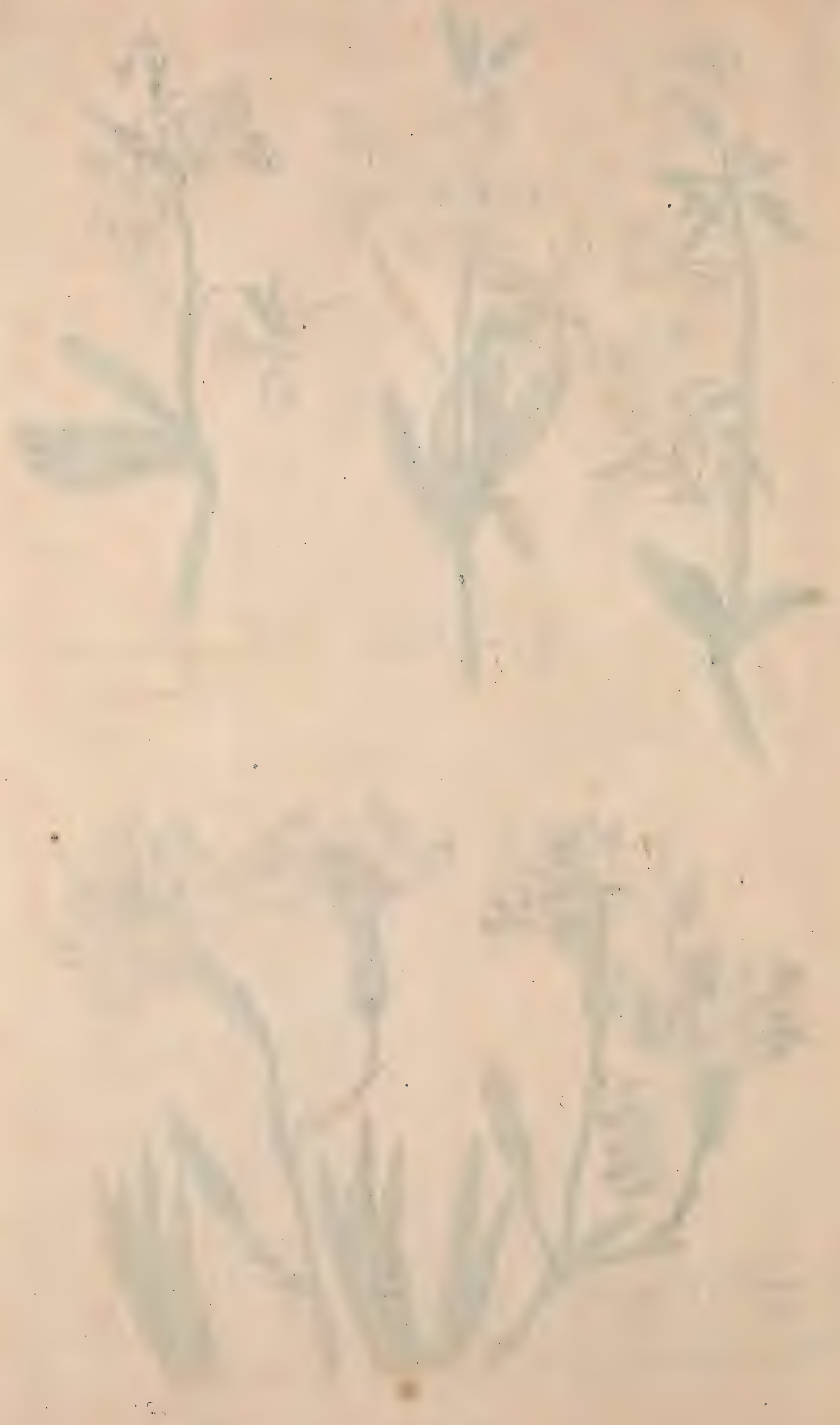




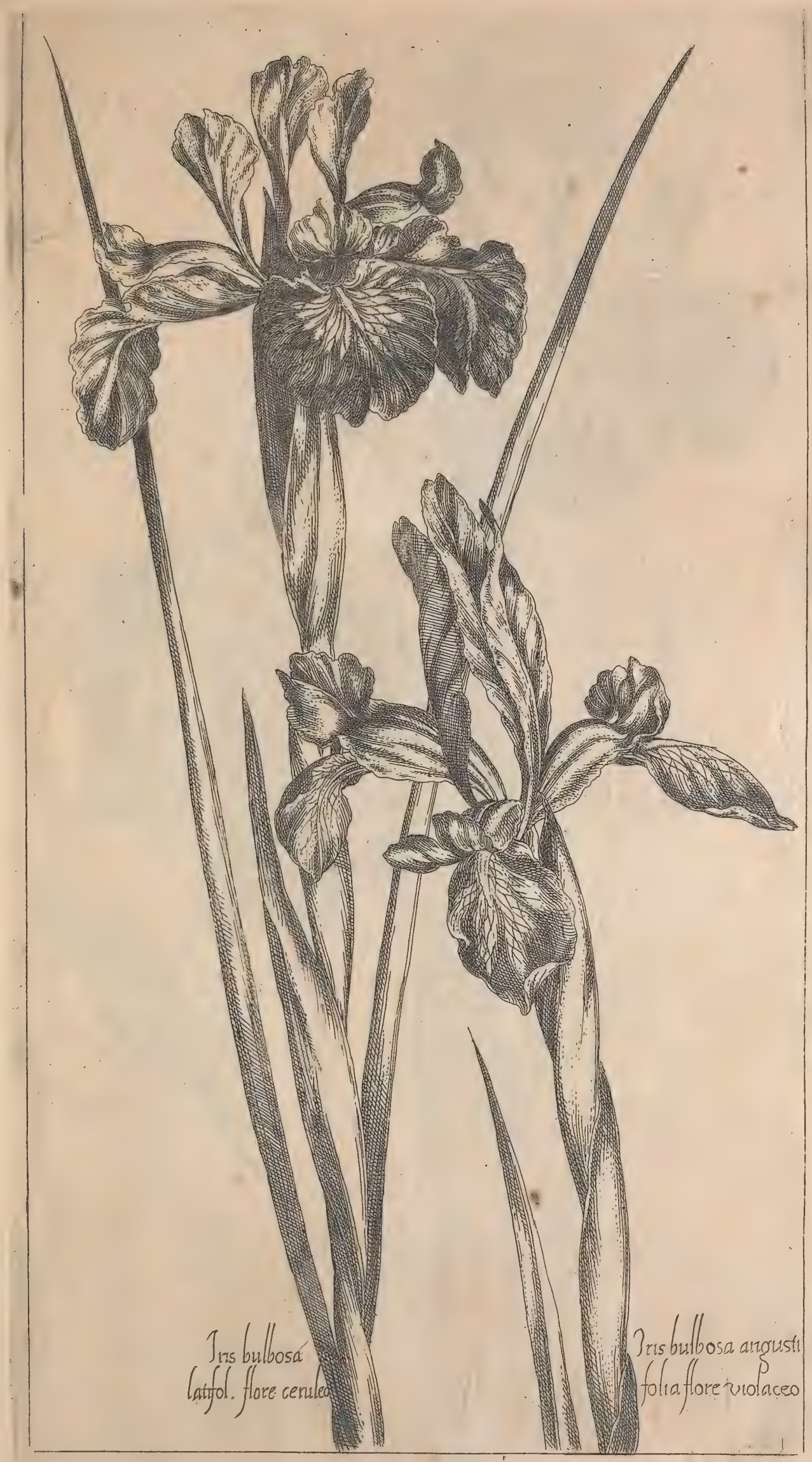





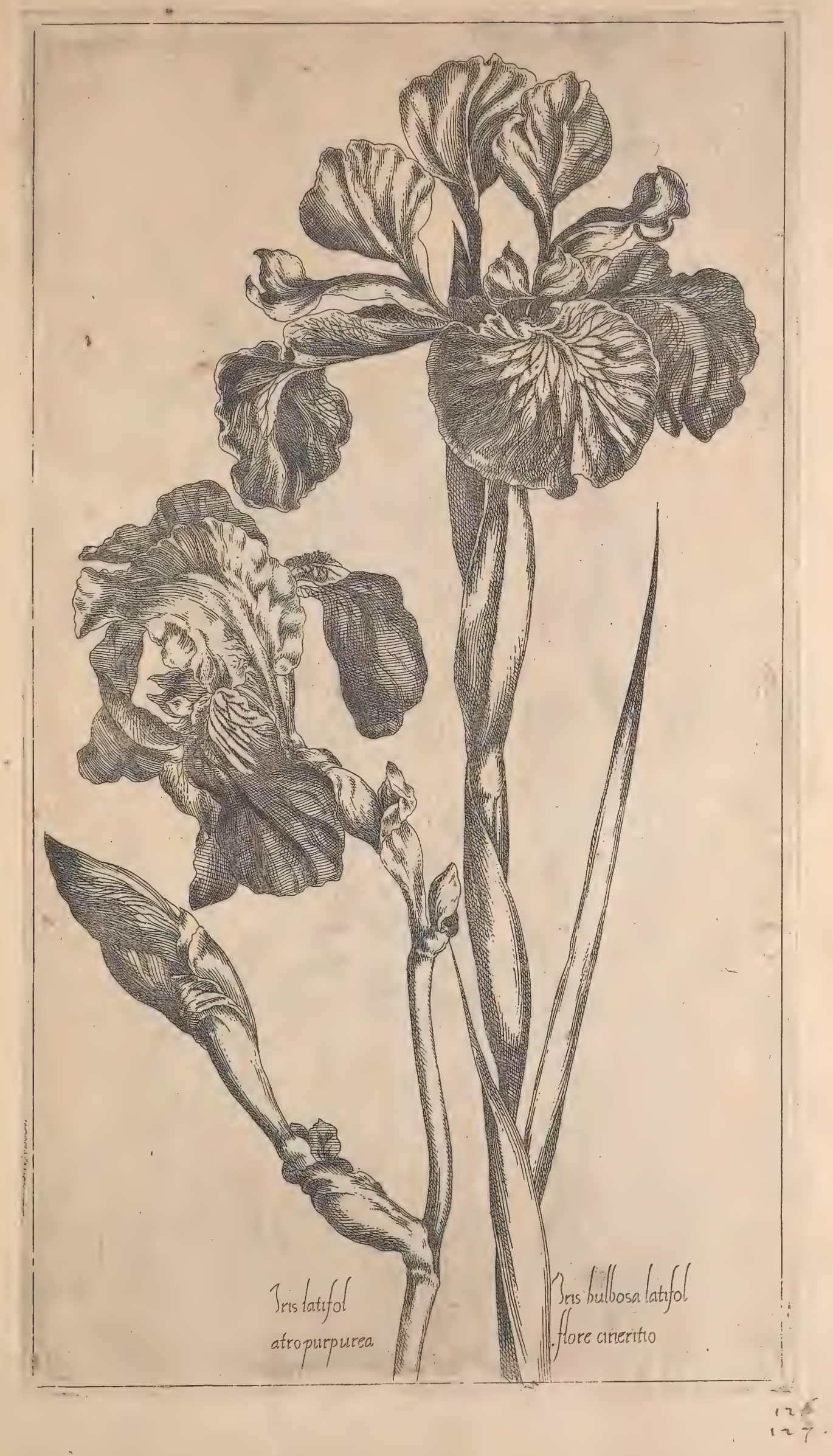





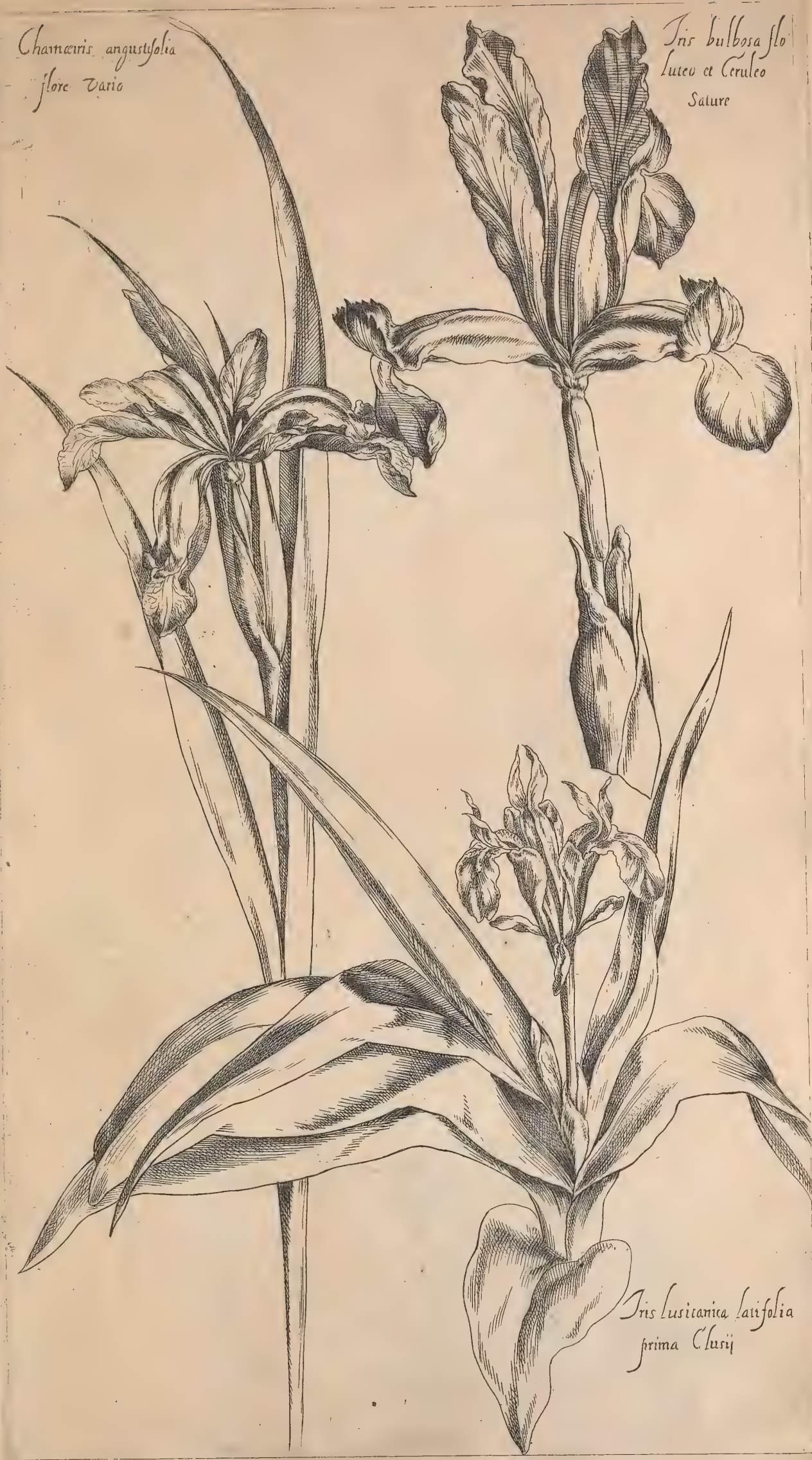





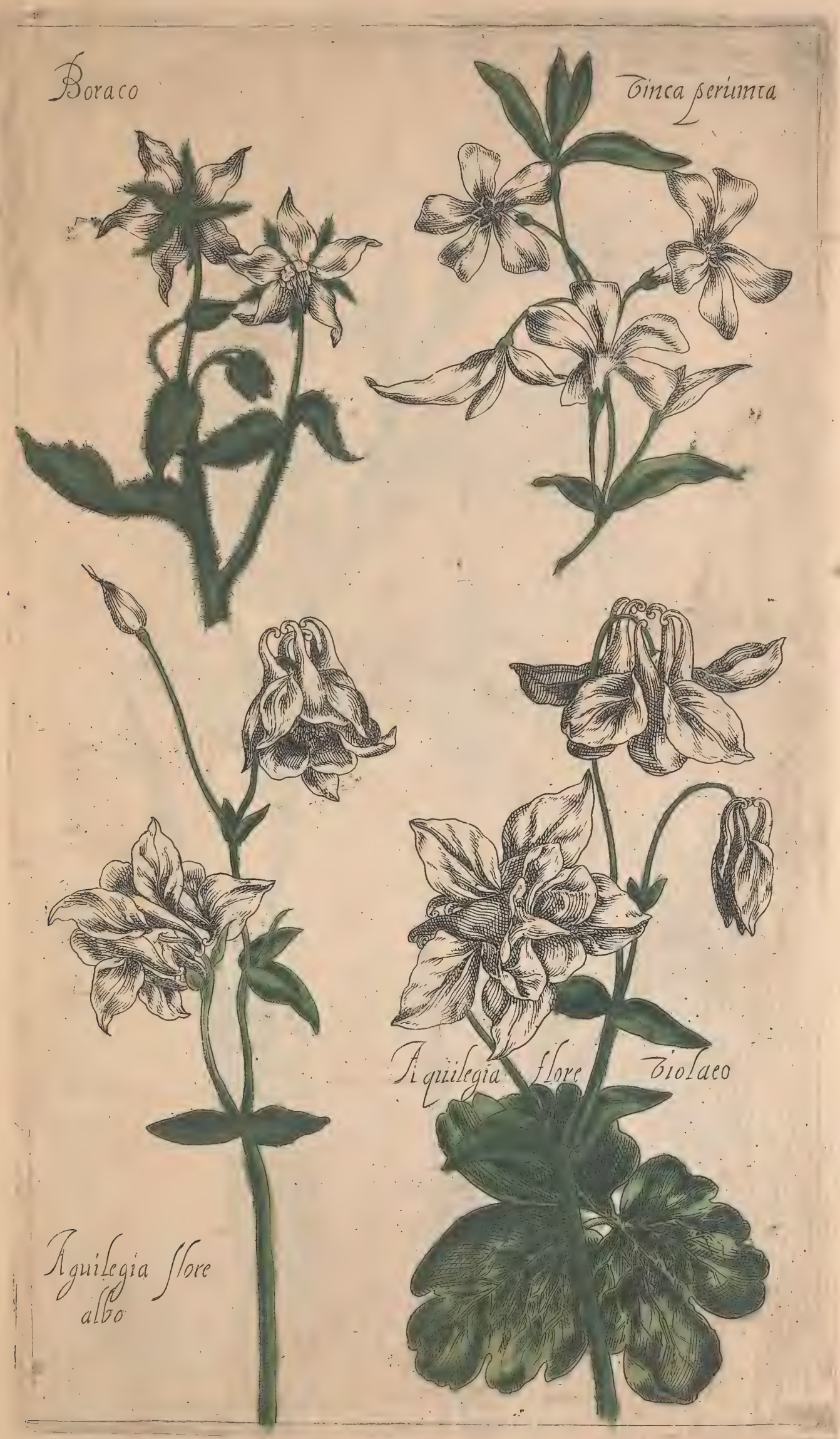




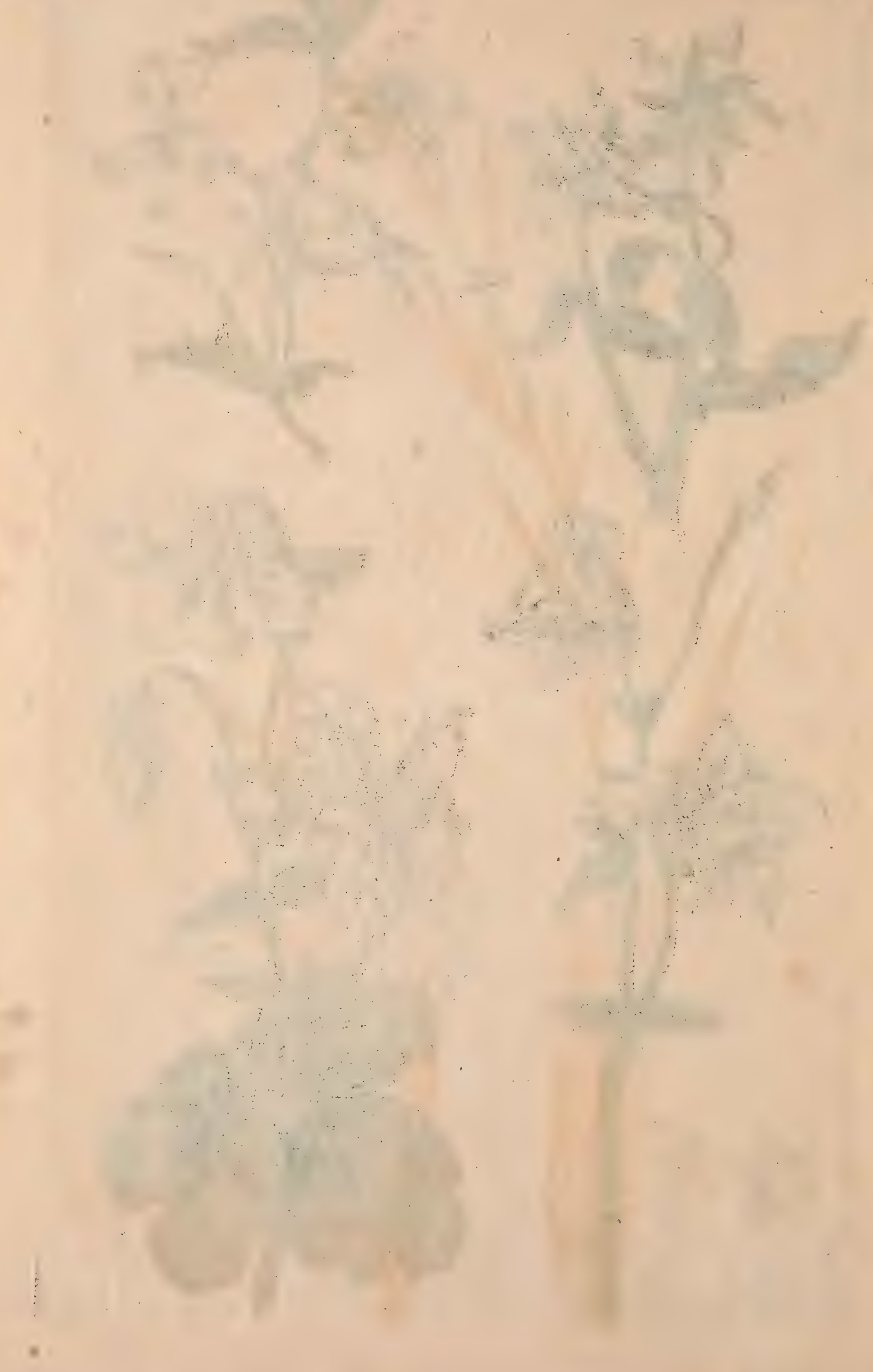




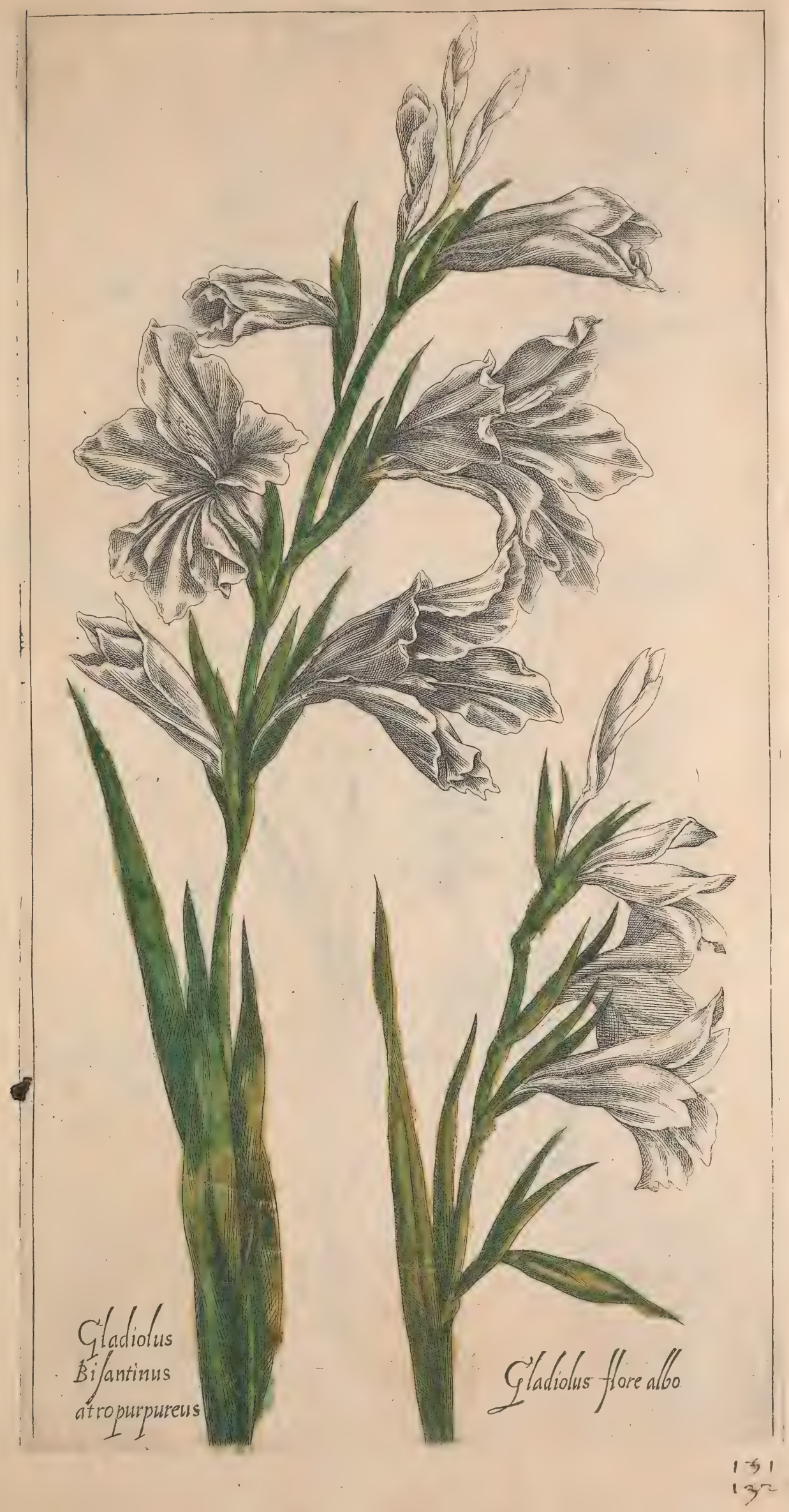





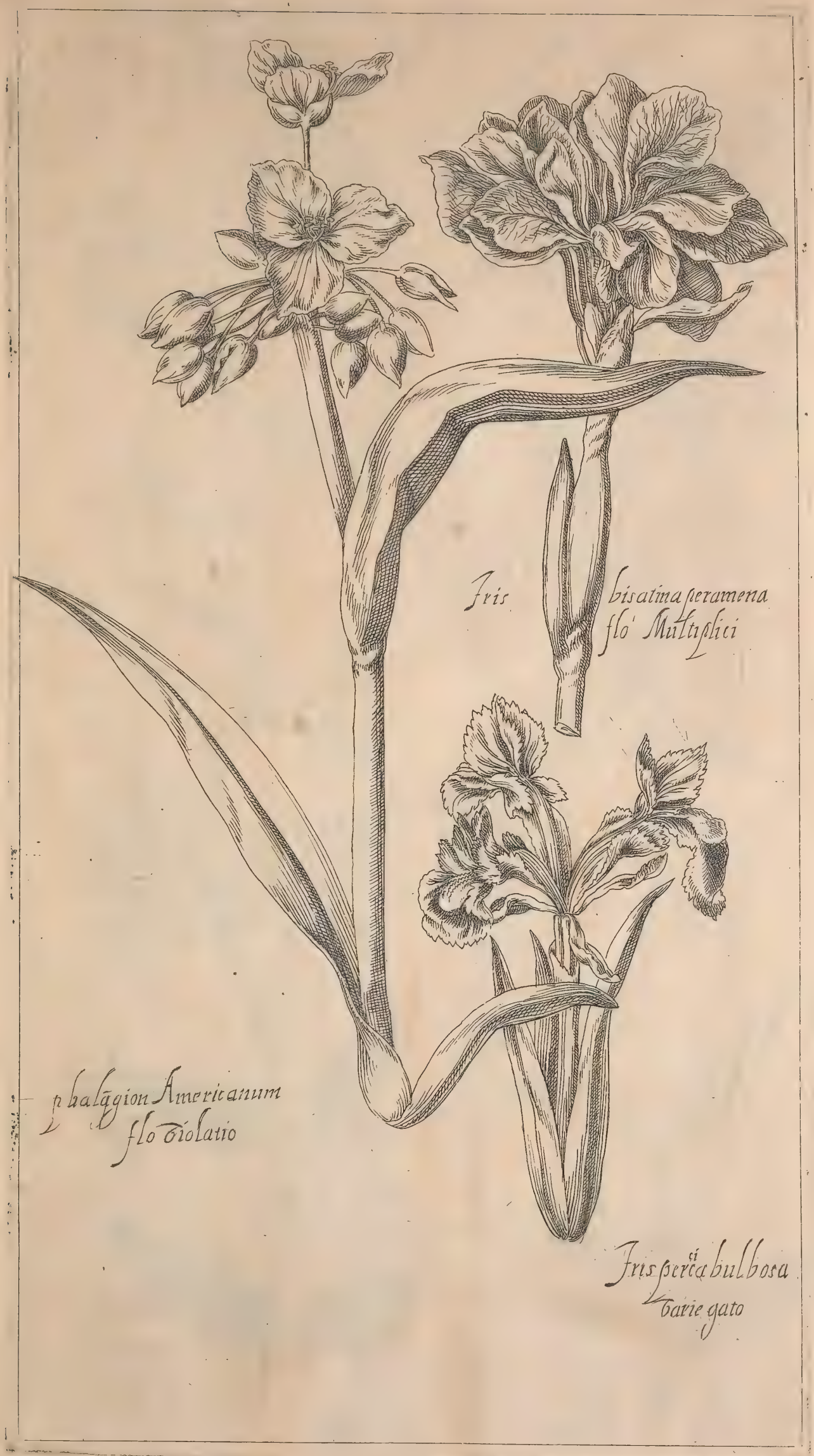





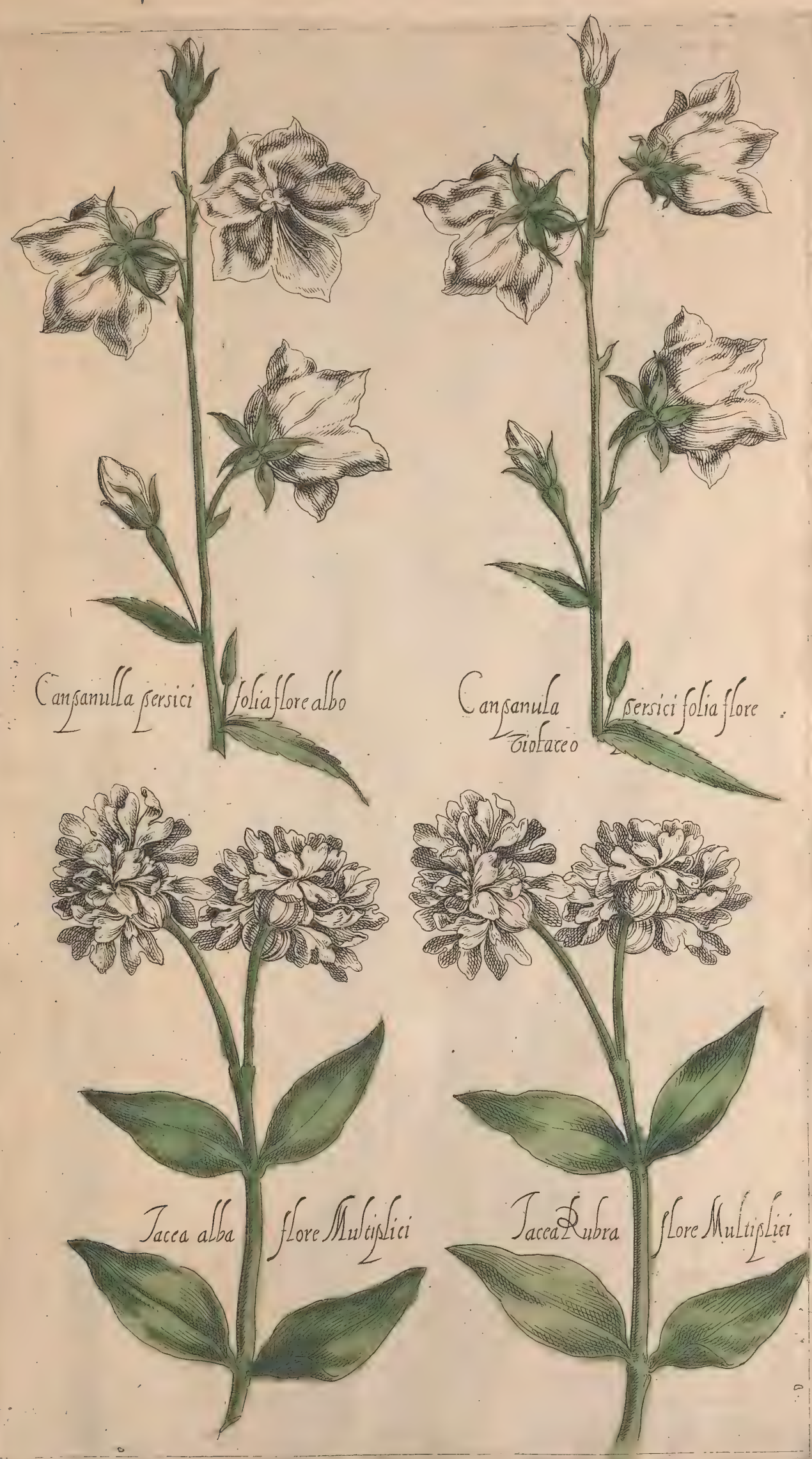




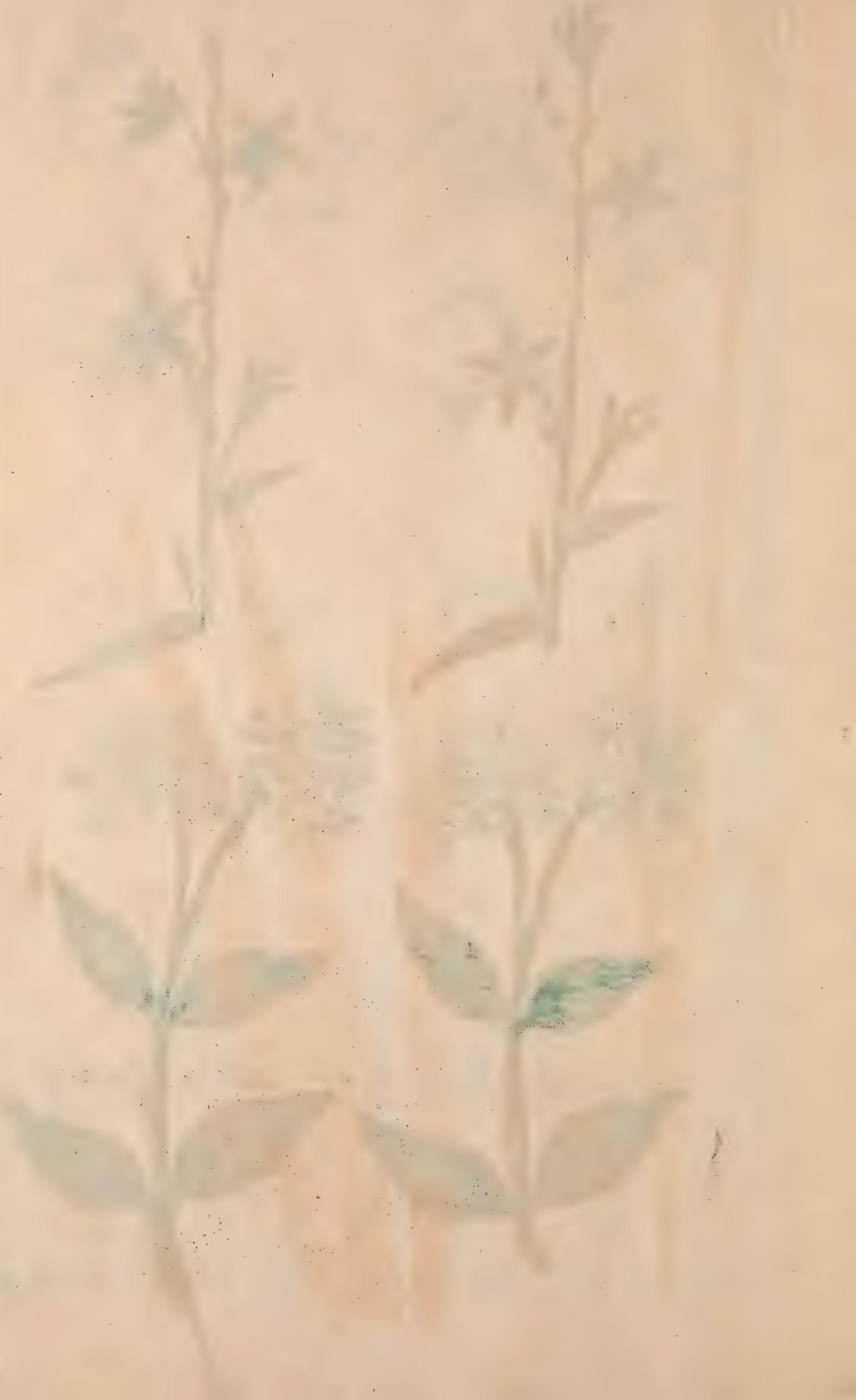




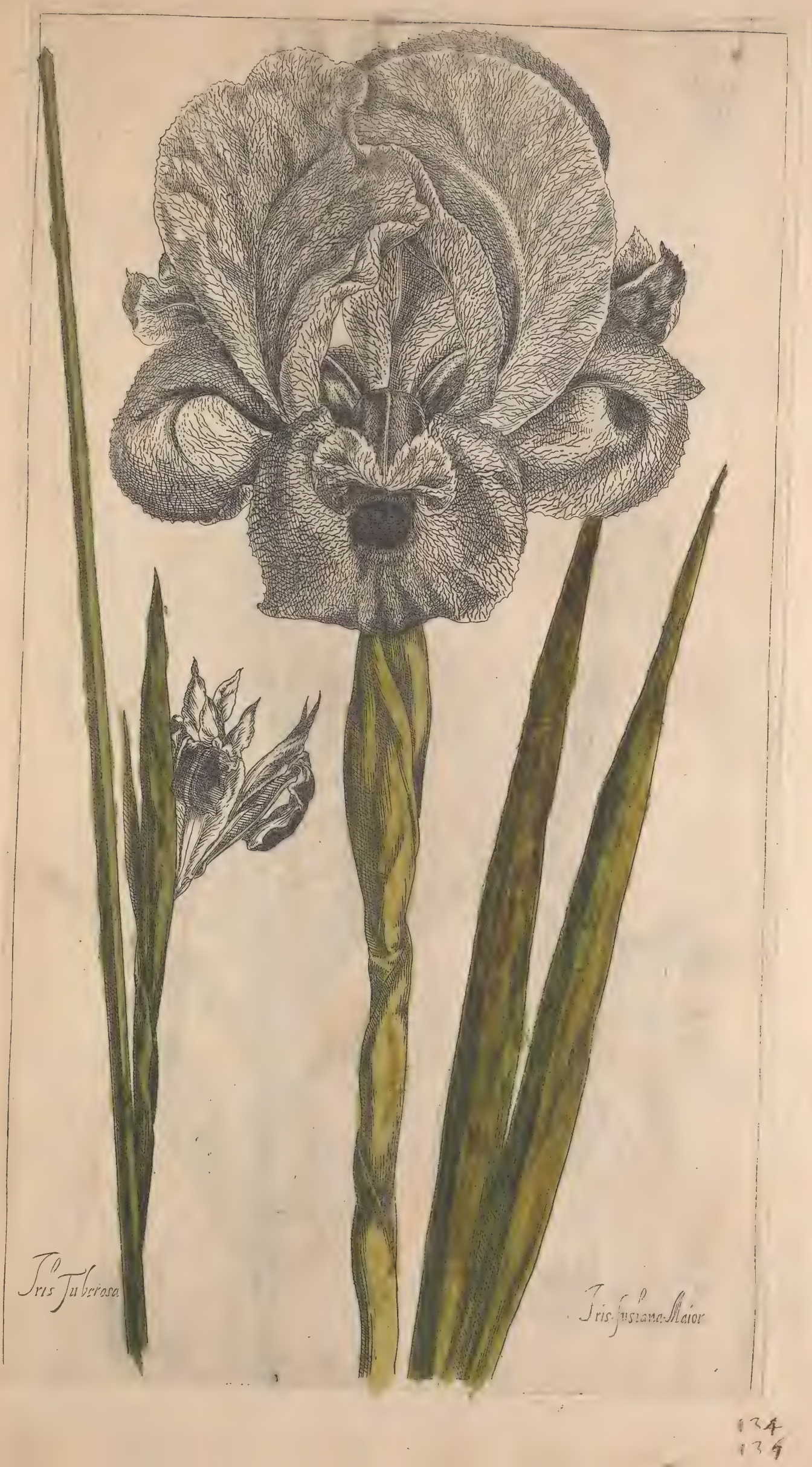





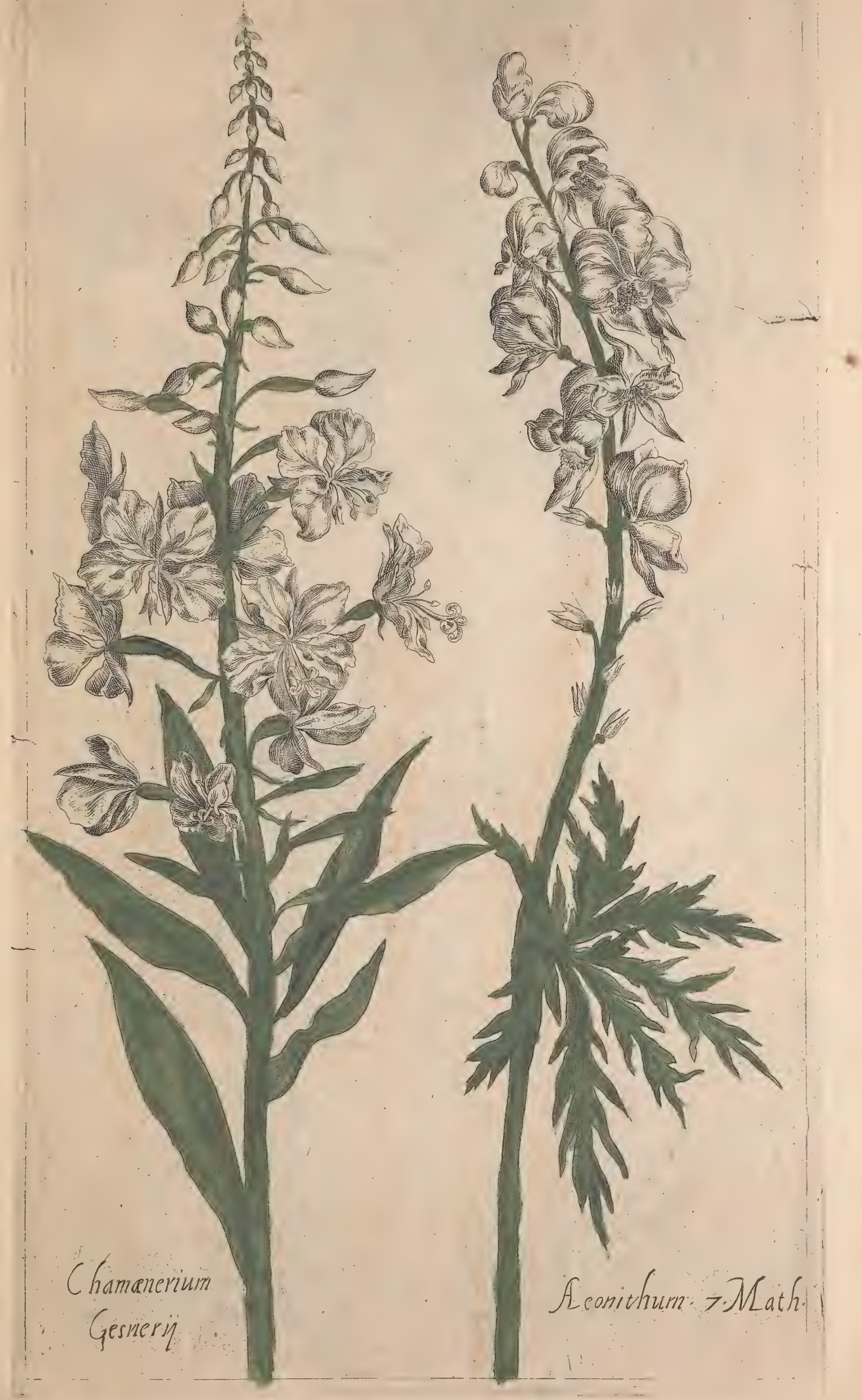





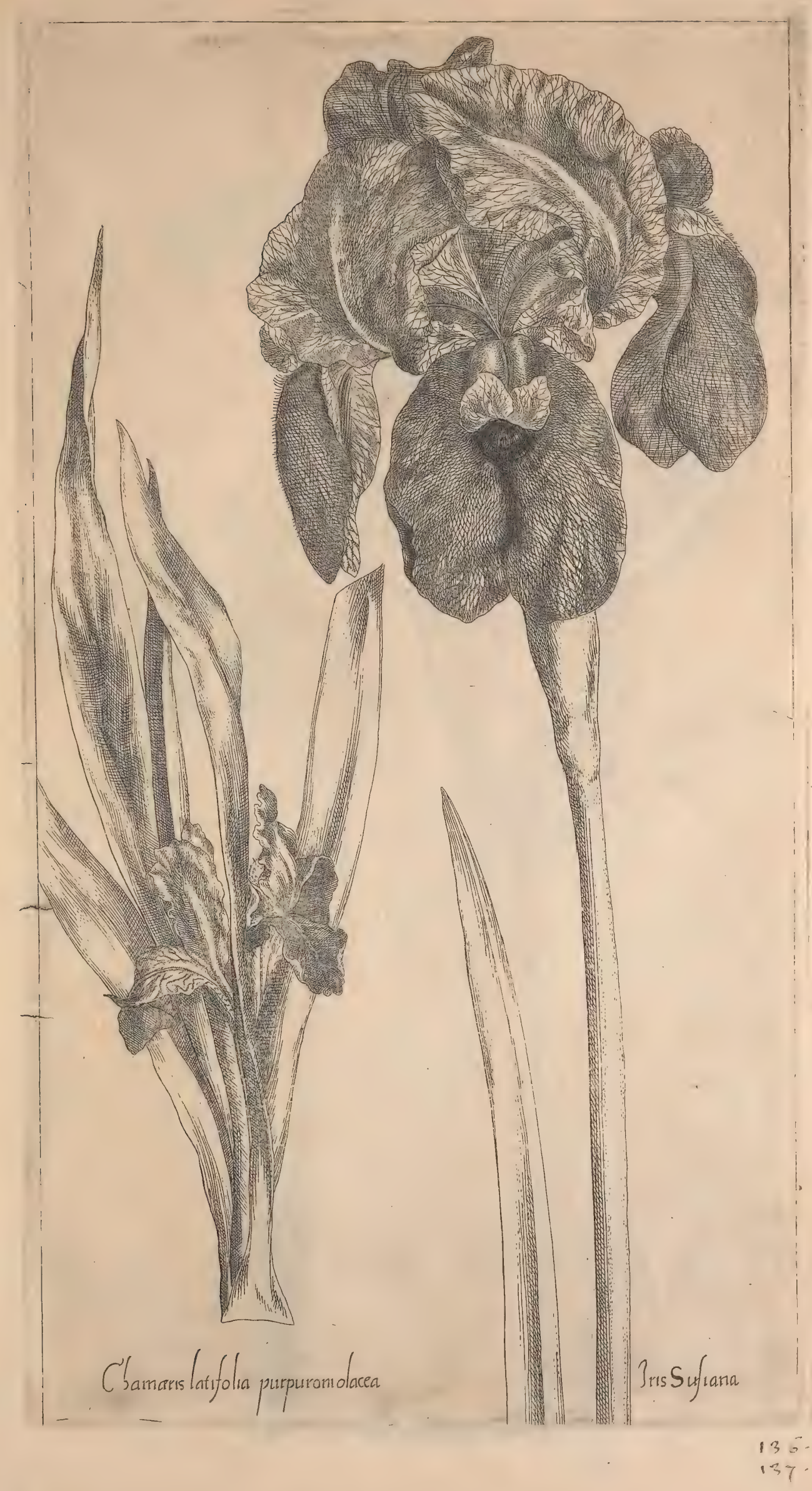





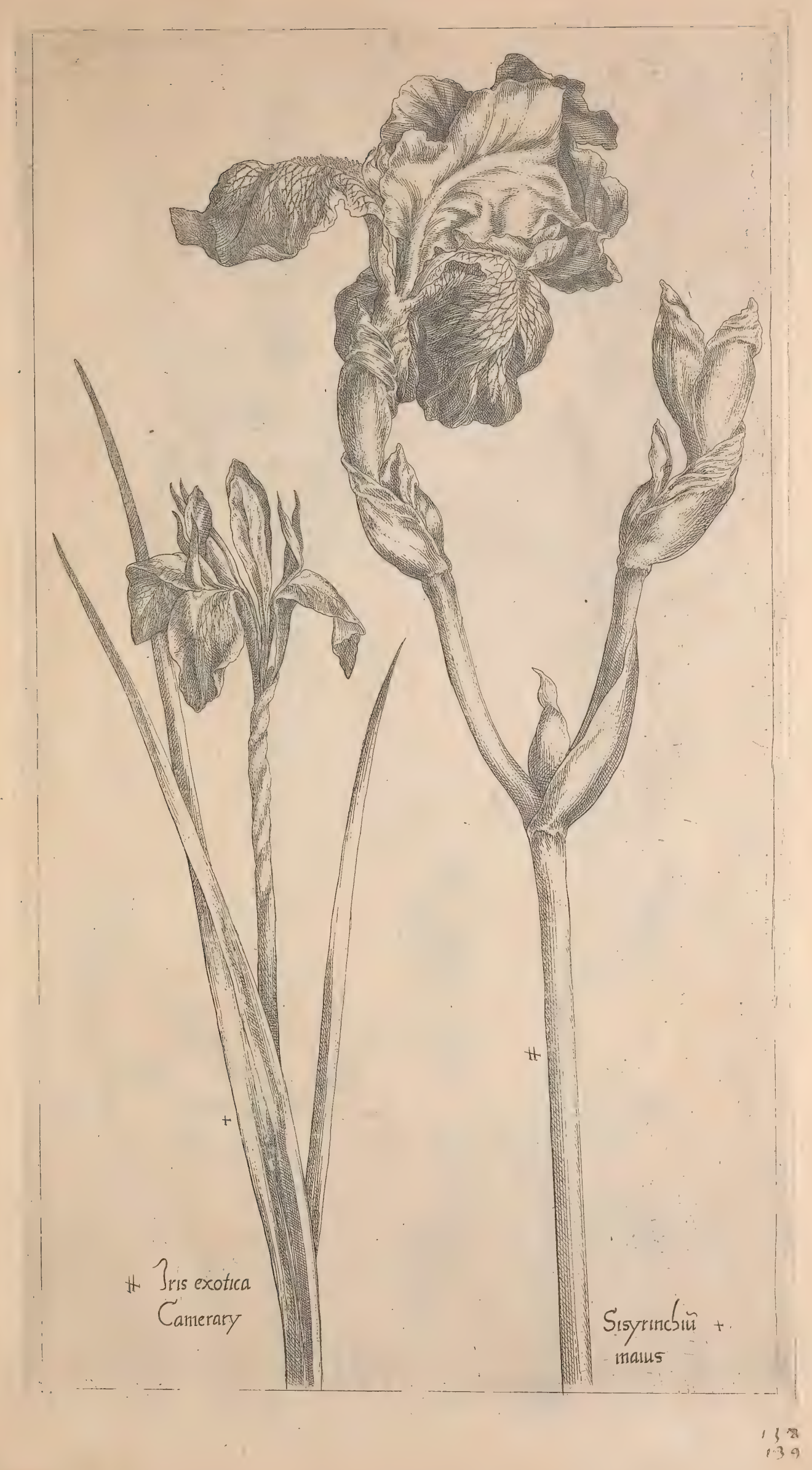





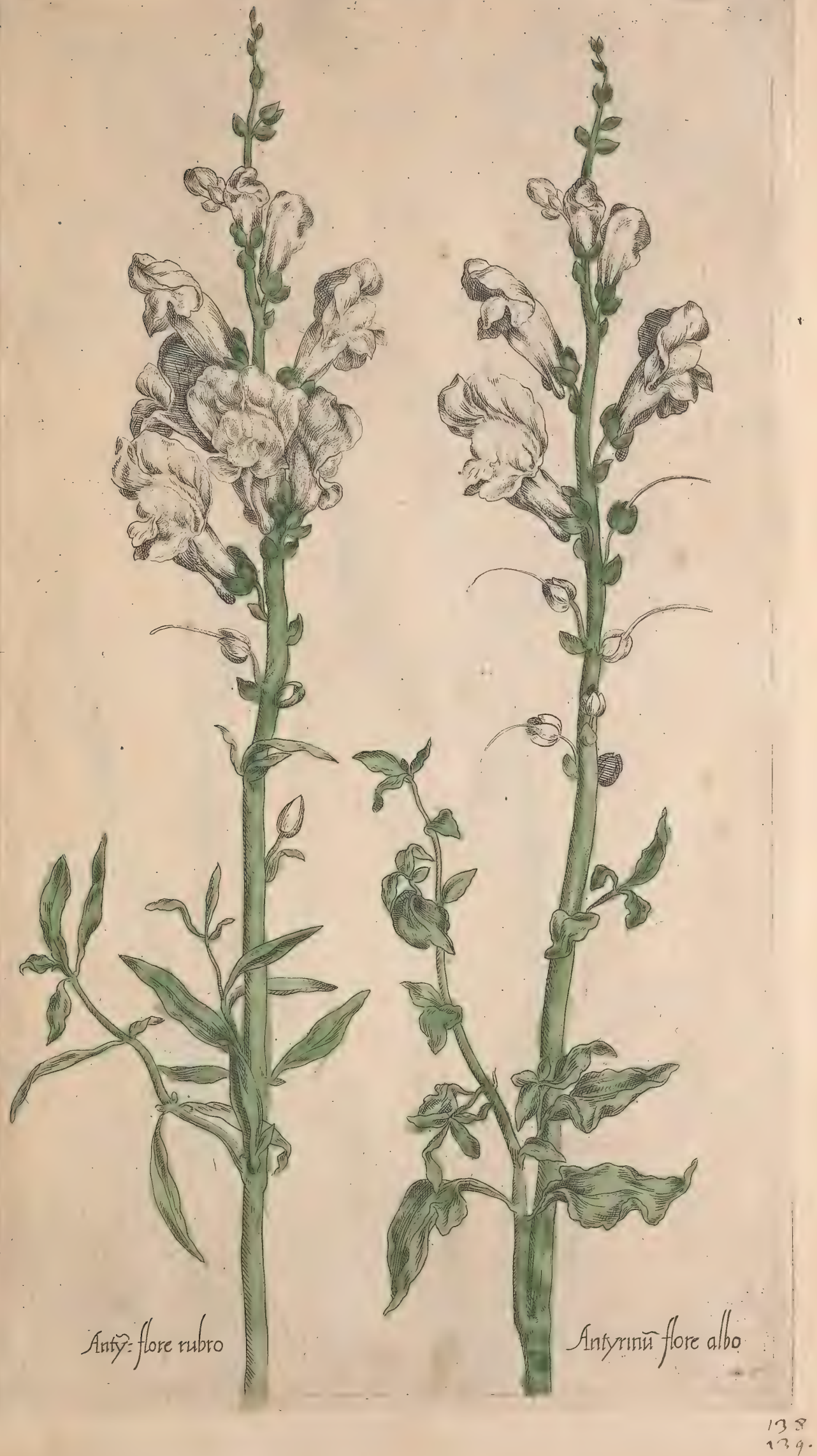





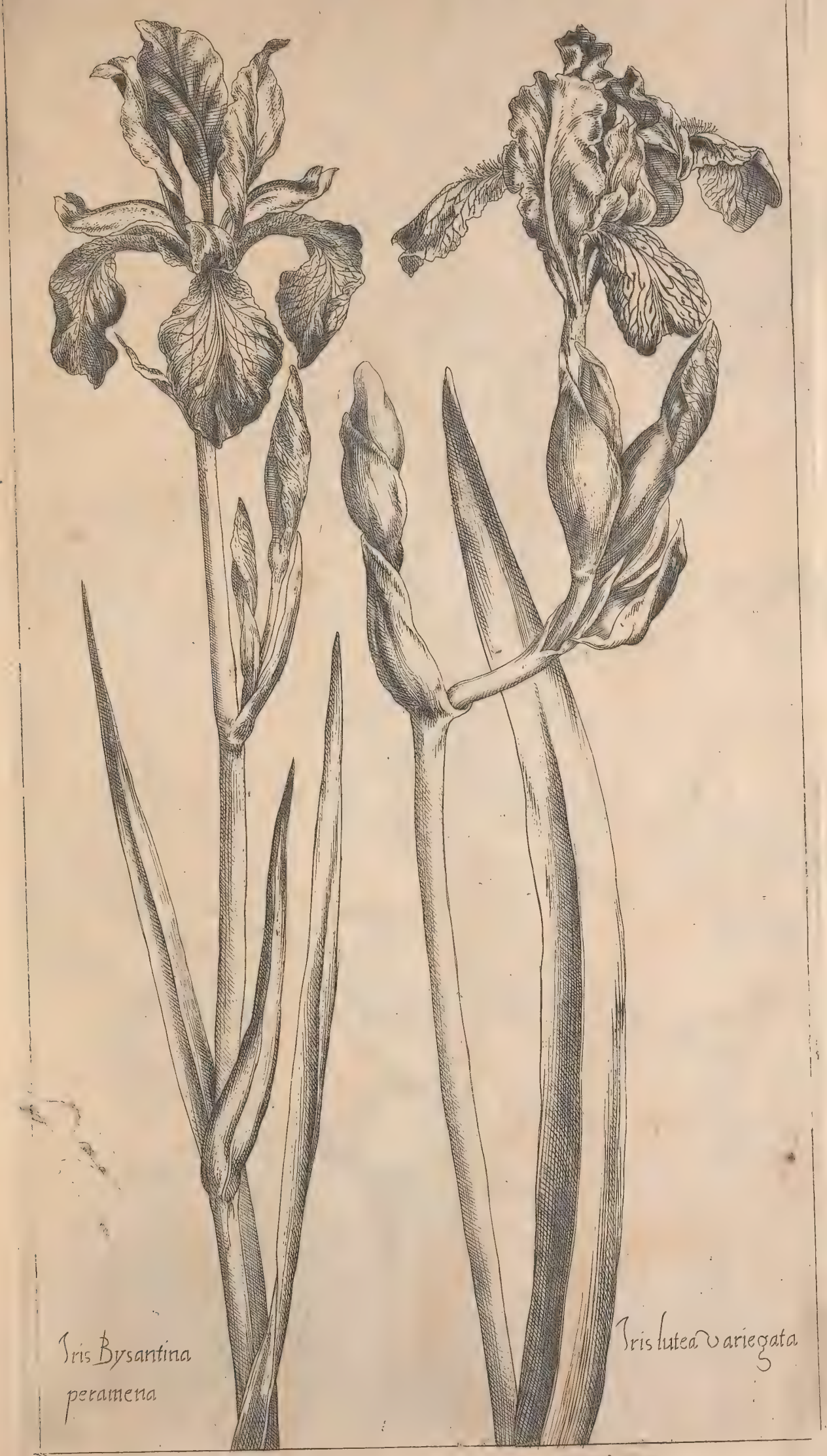

145
14 



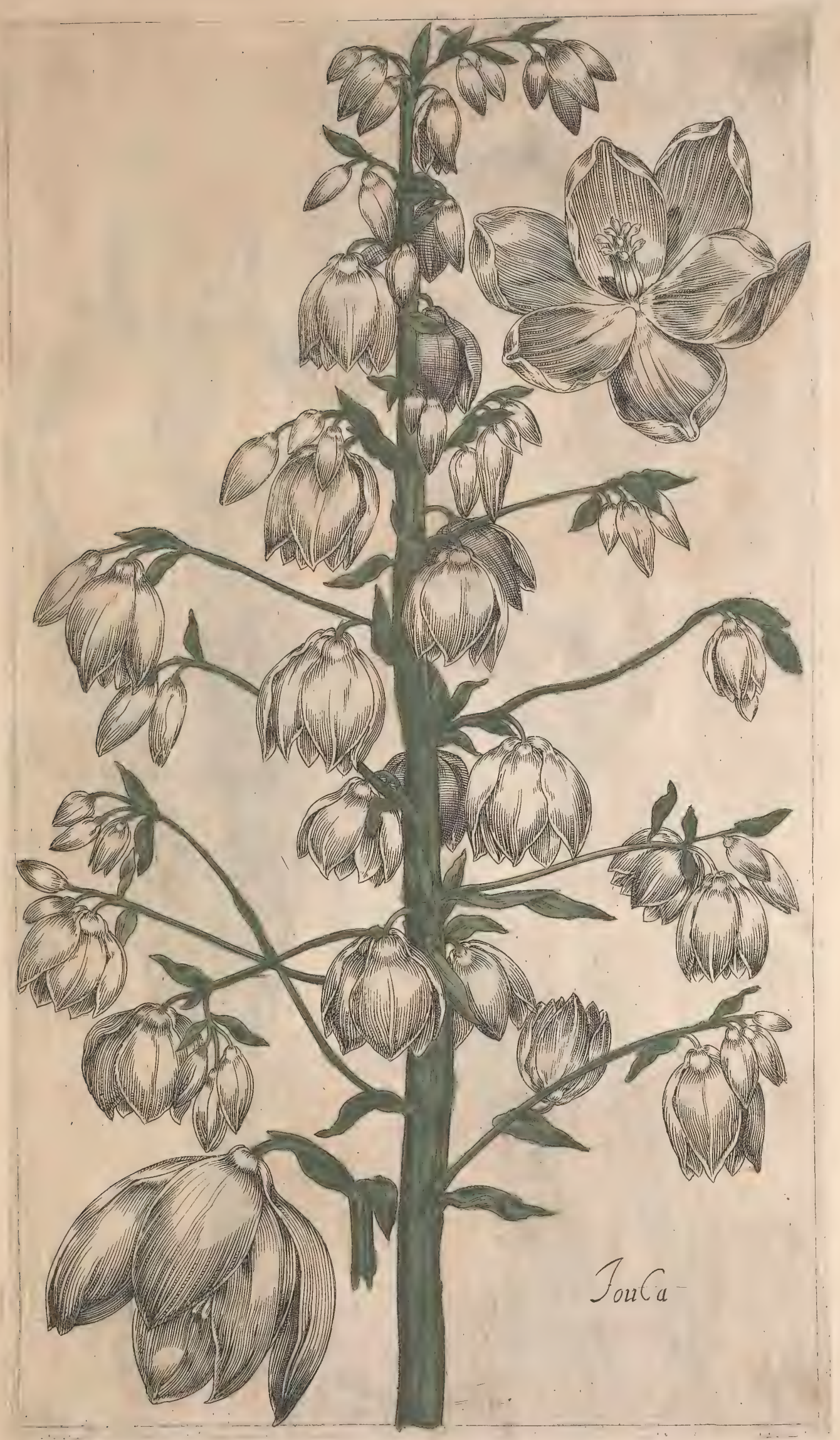




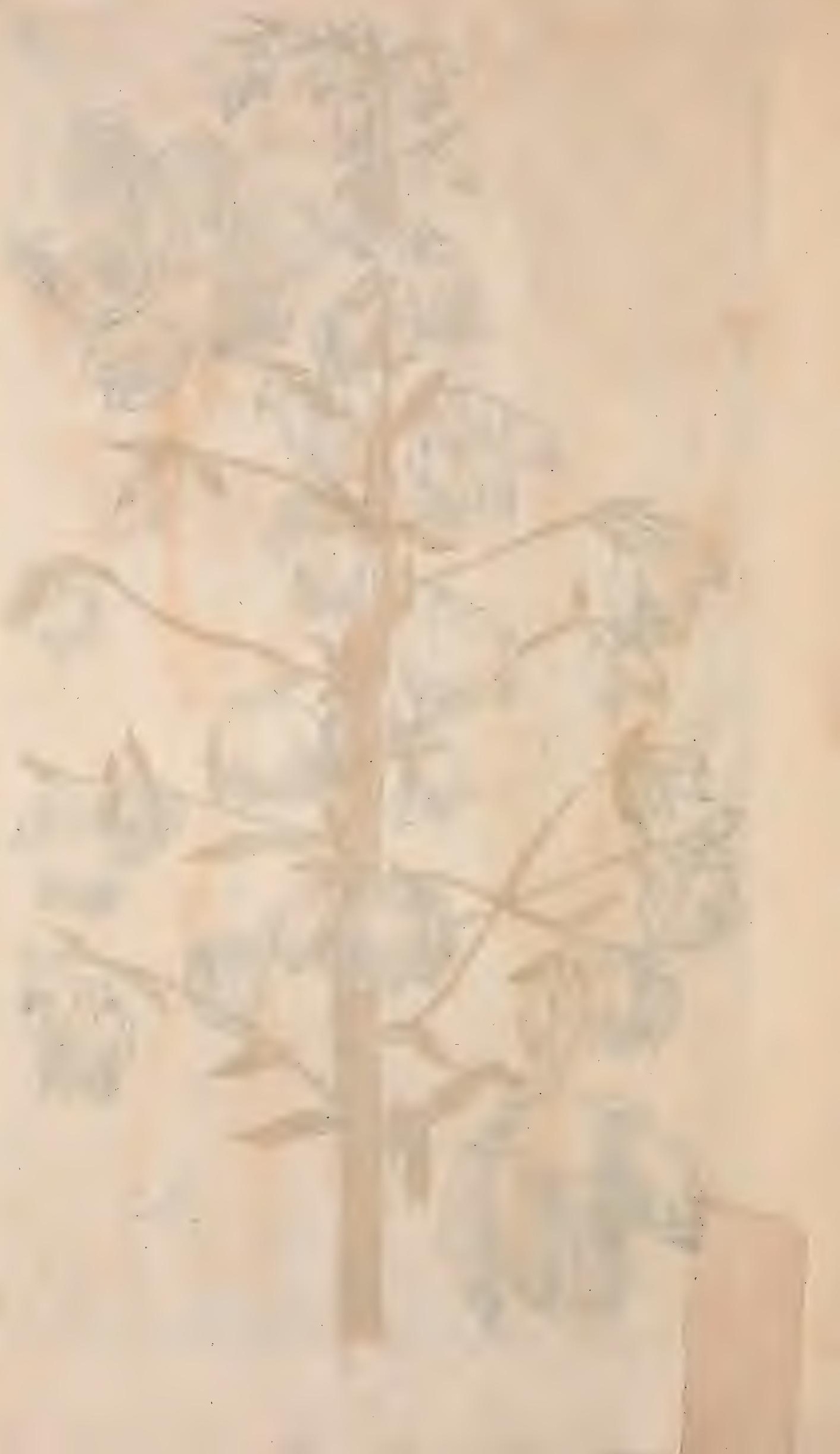




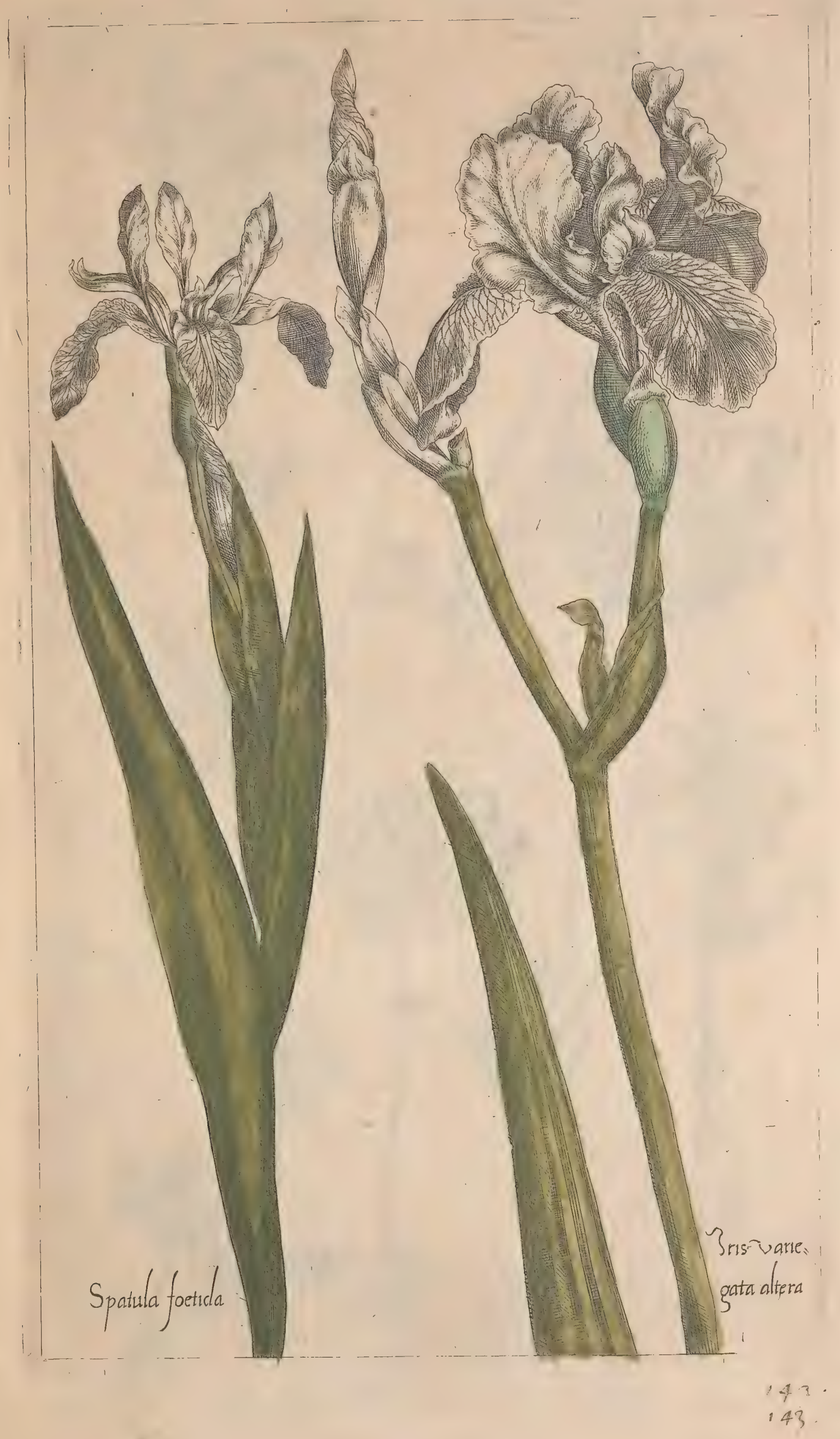





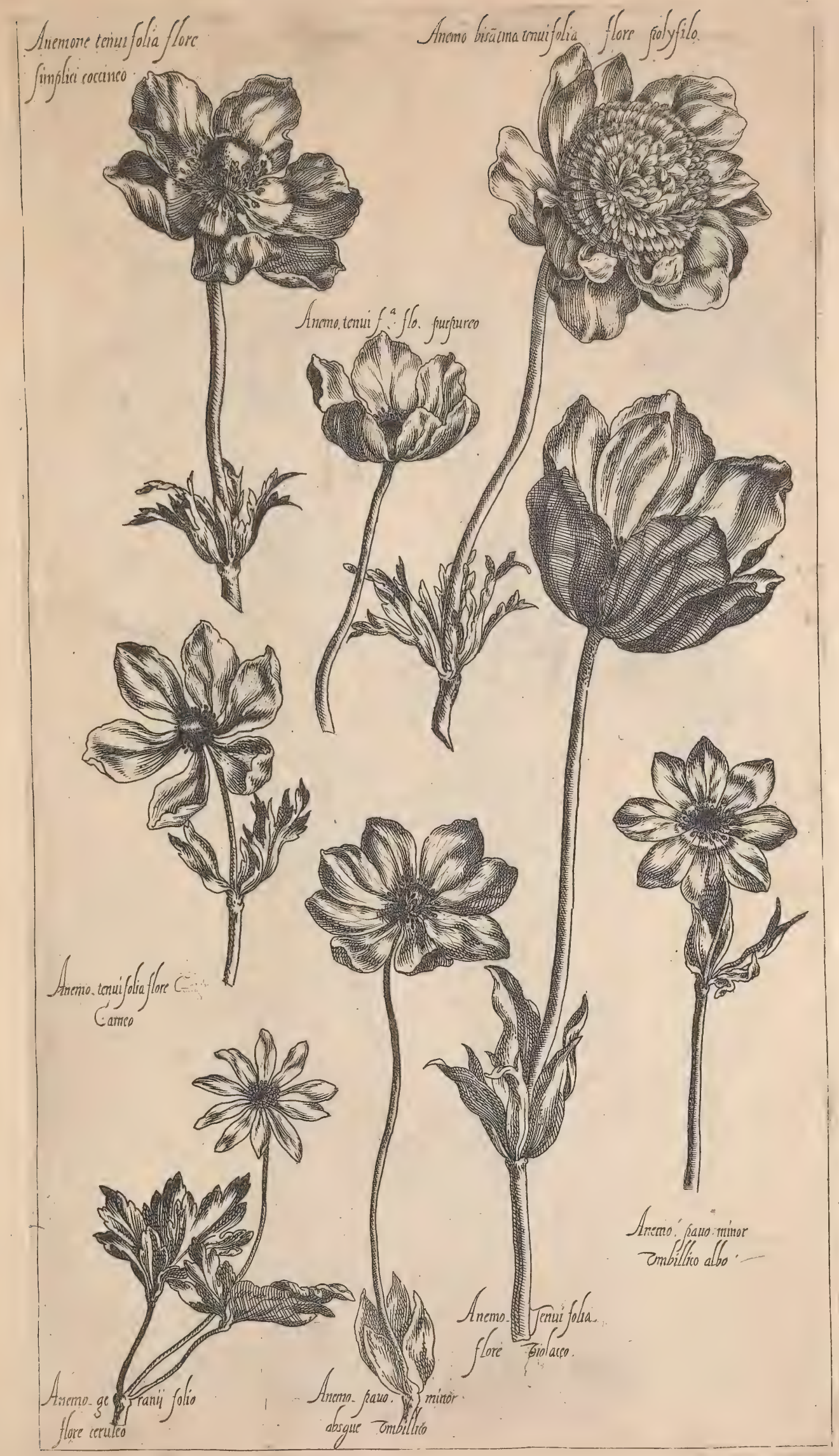





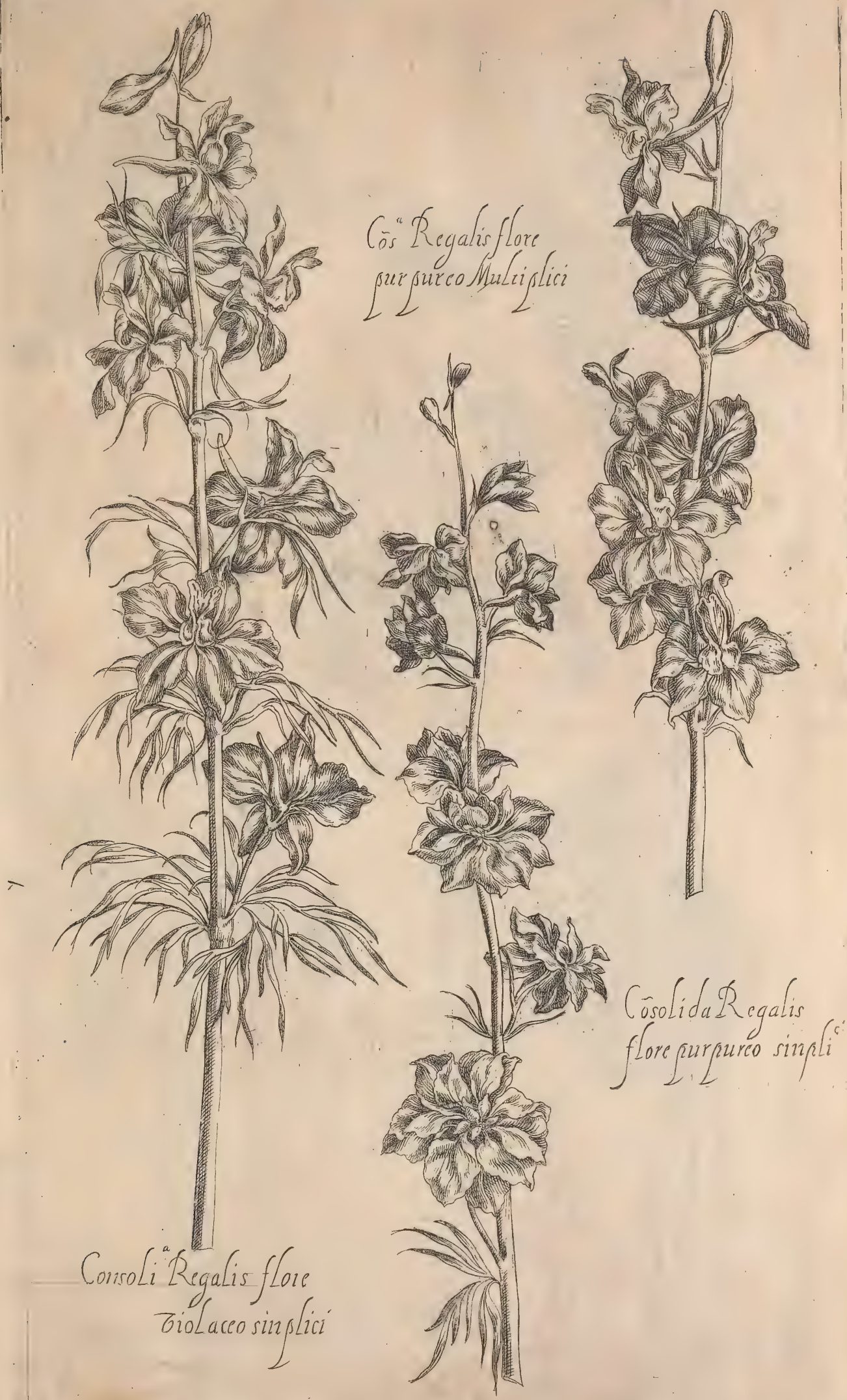




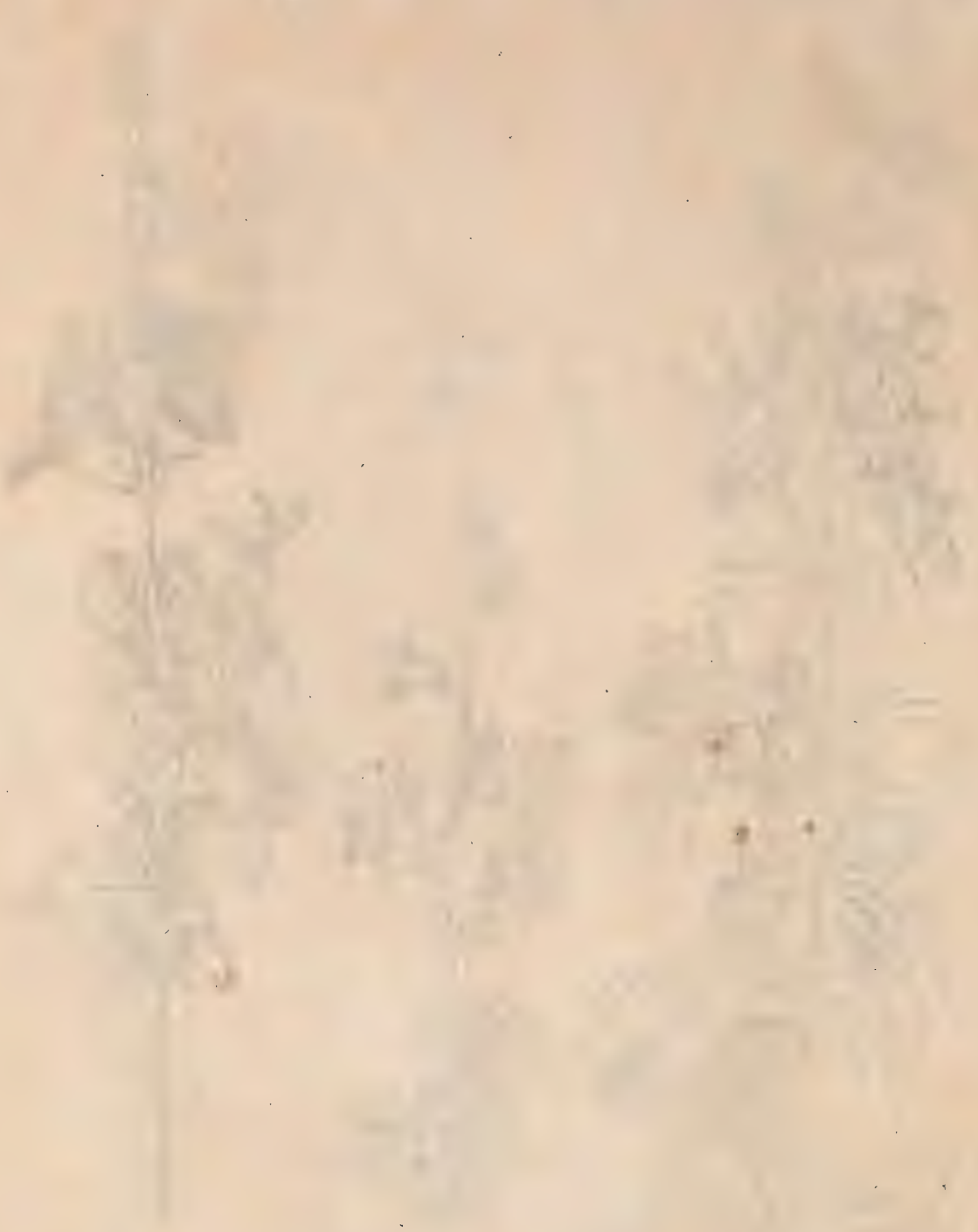




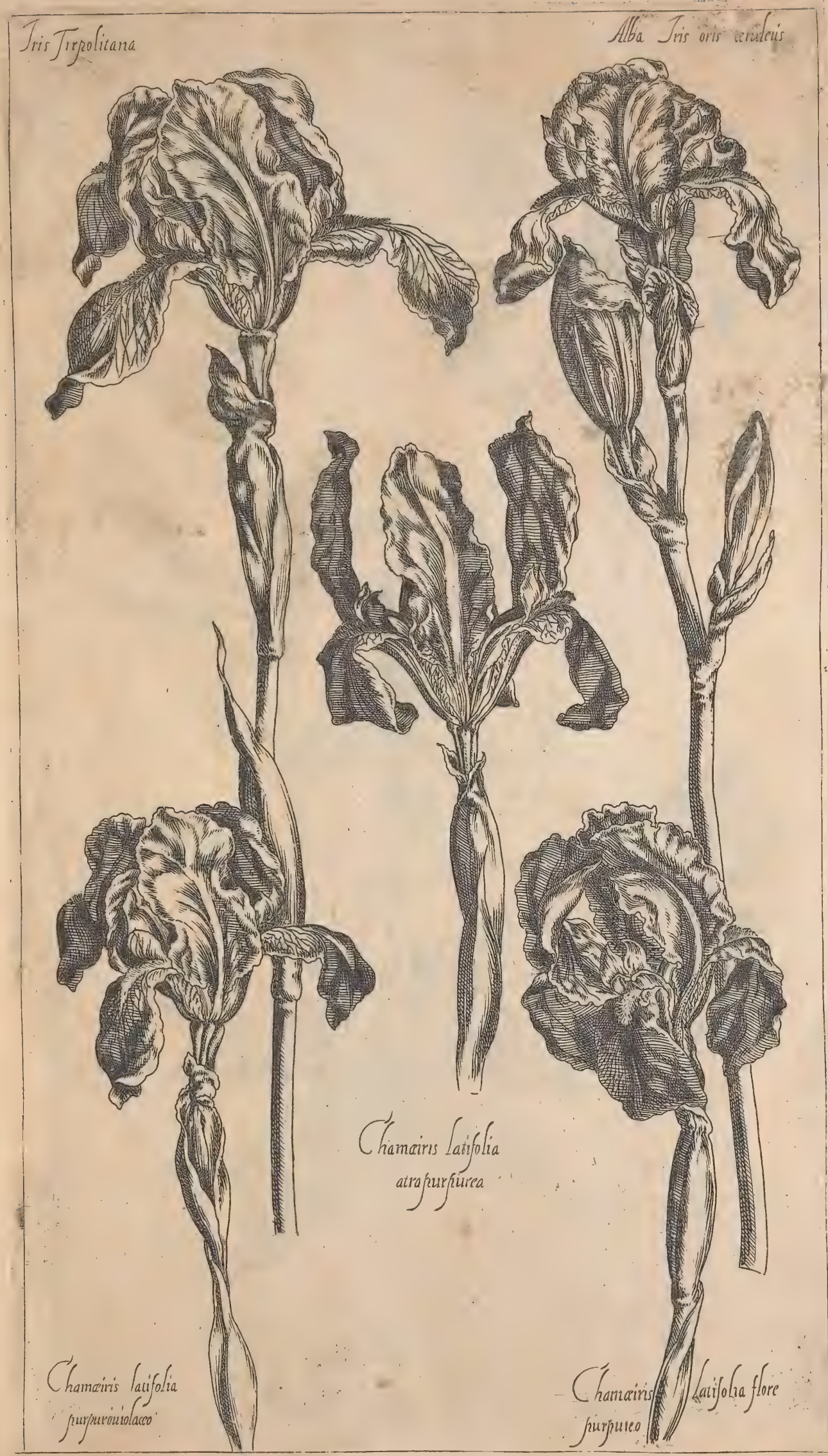




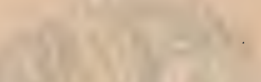

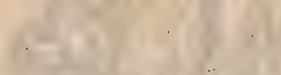

$\therefore+1+1$

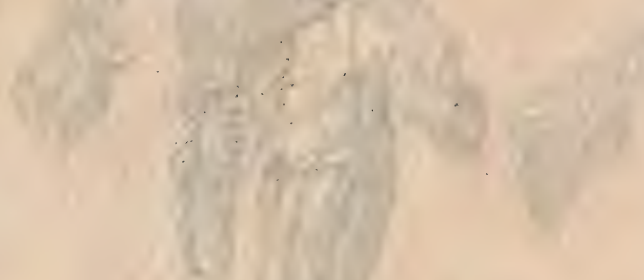

| 10

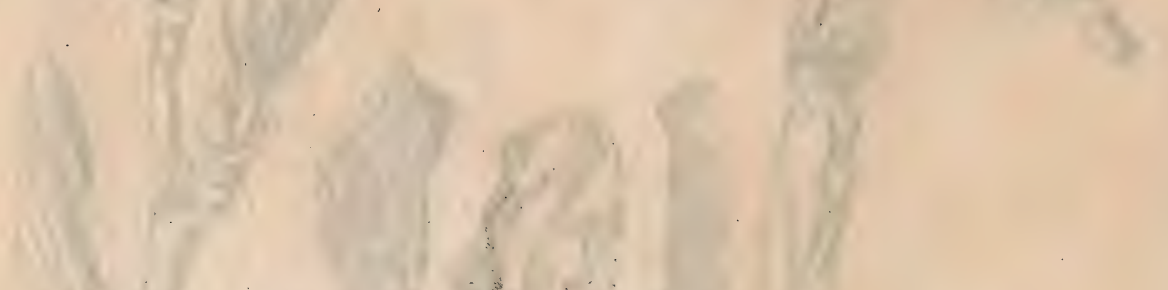

1):

1.

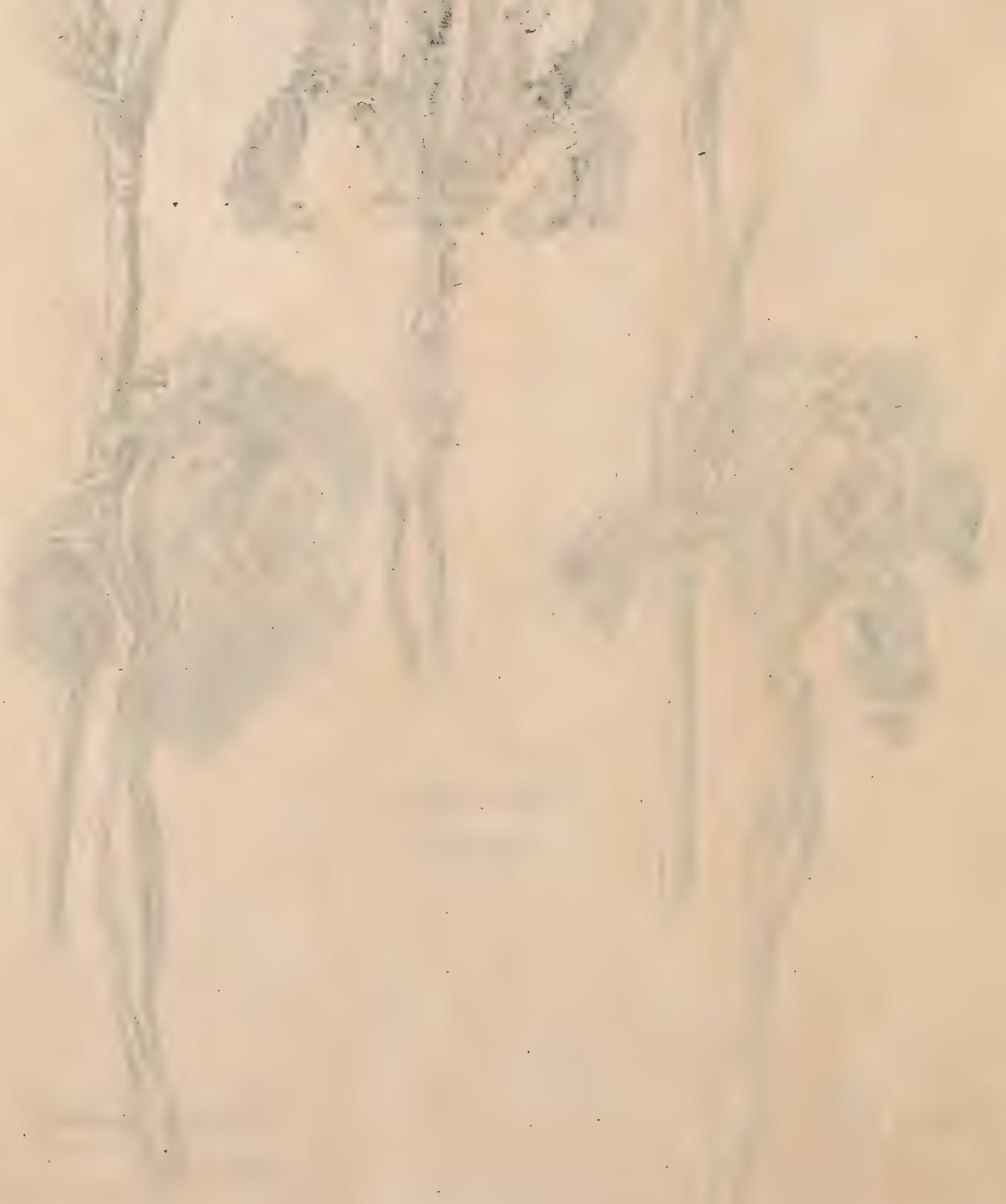




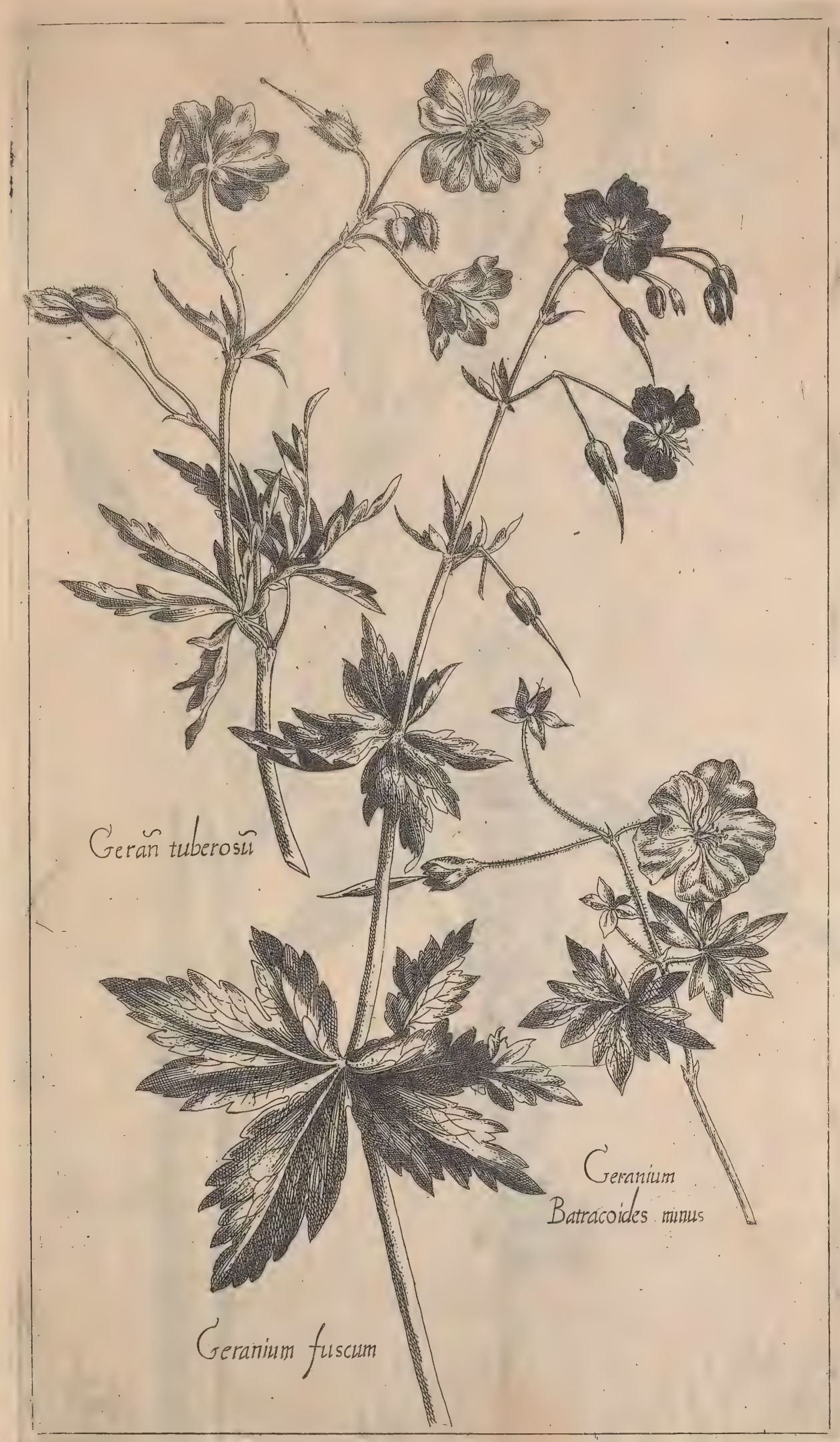




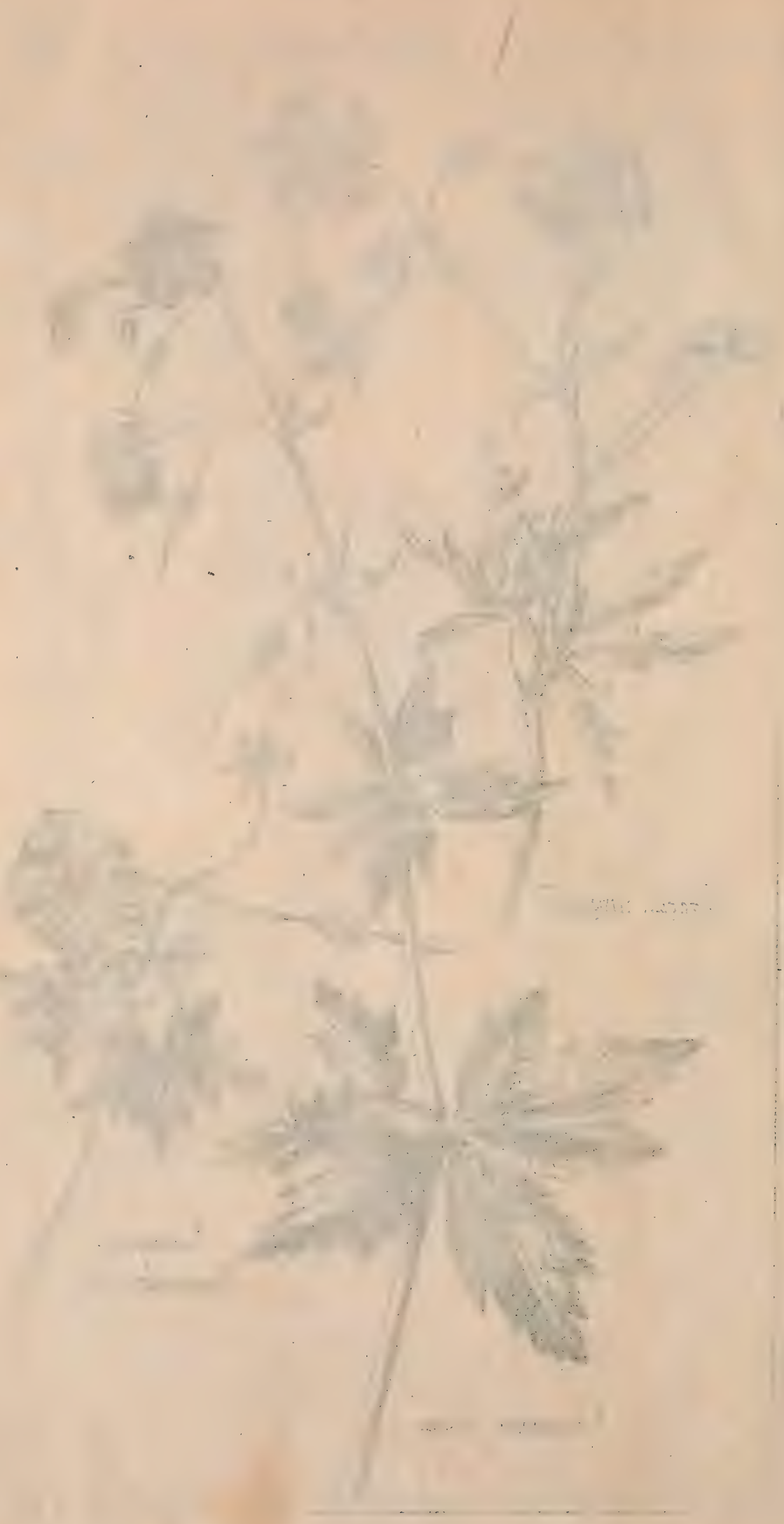




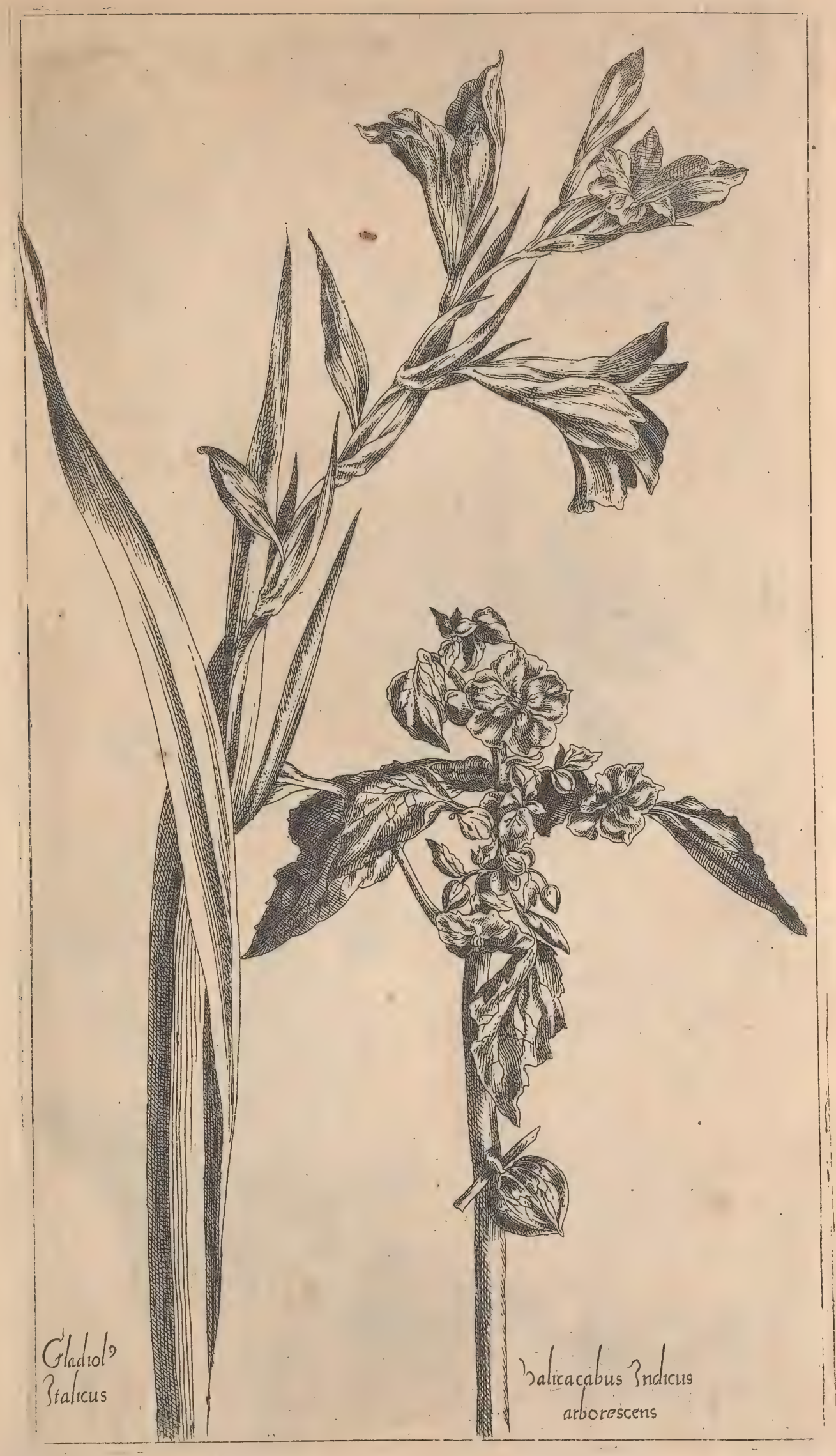





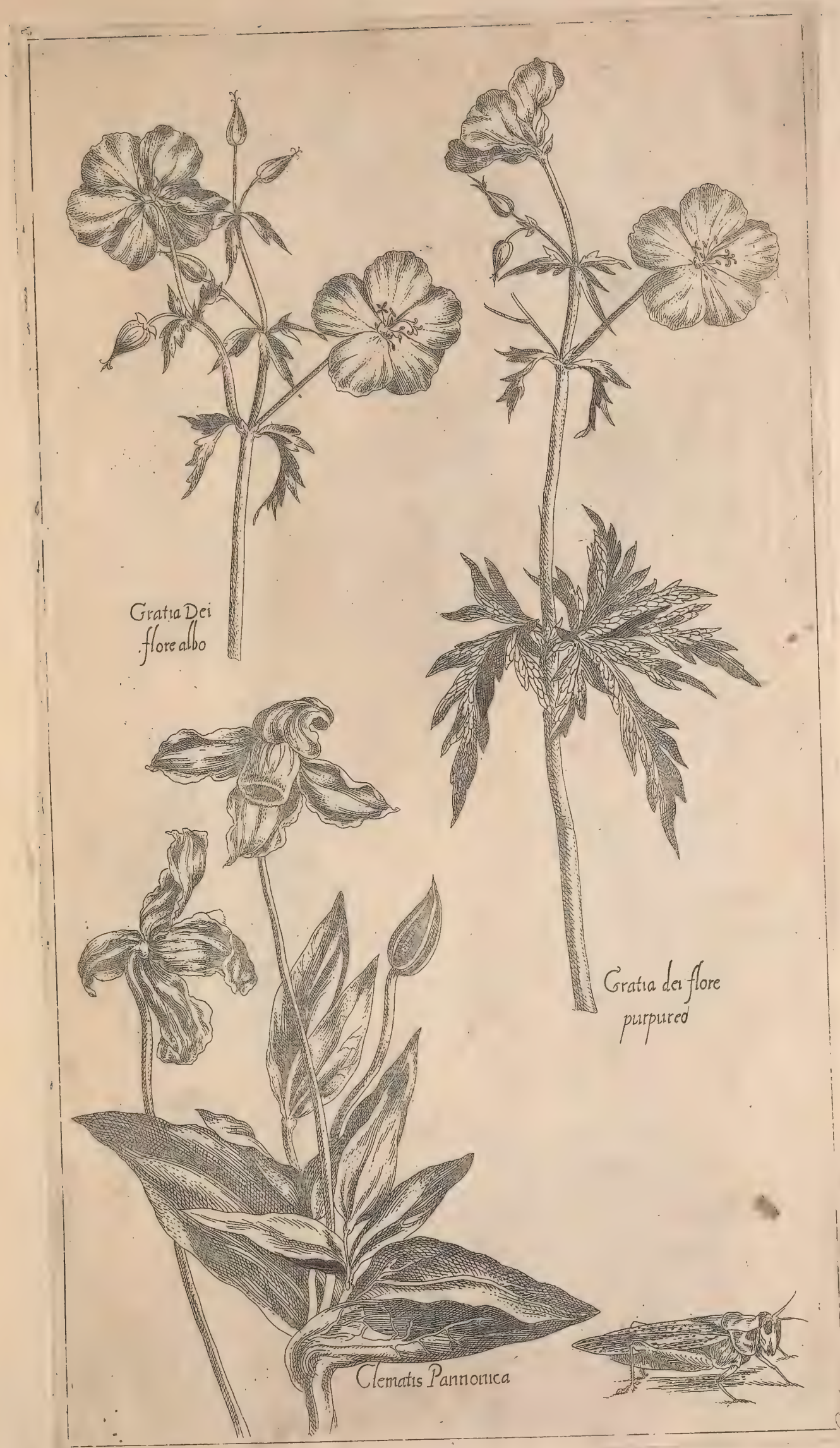





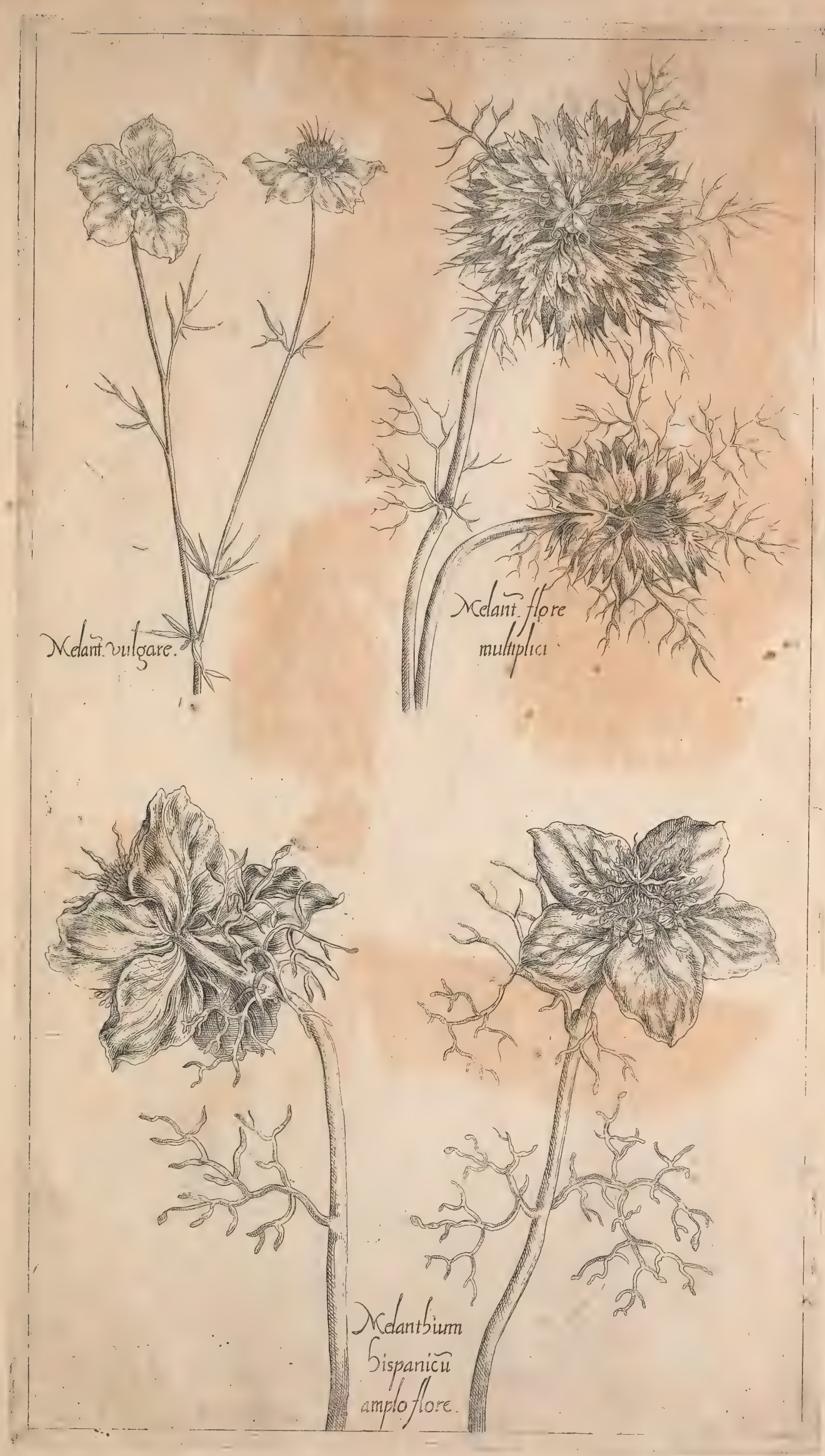





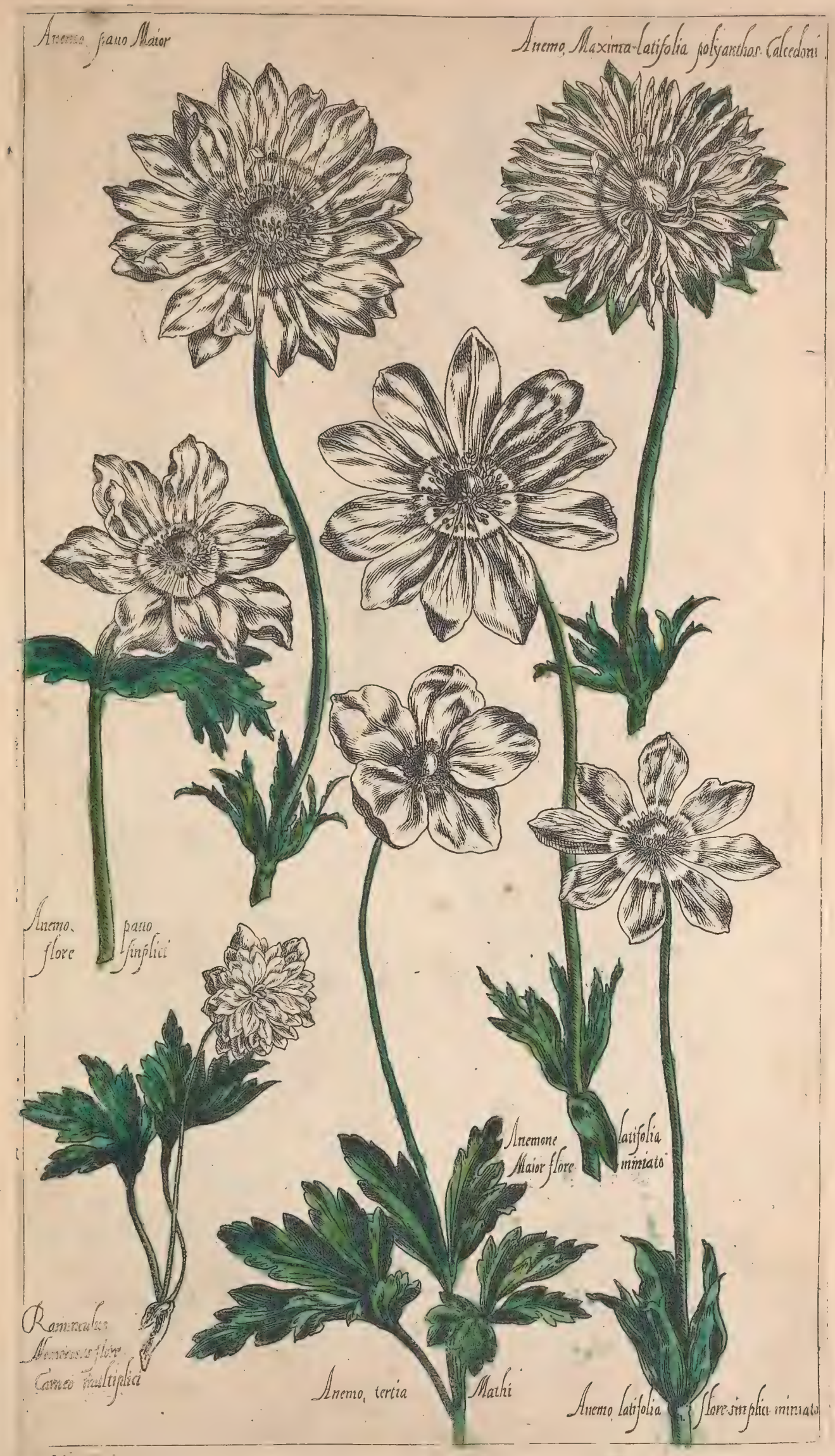





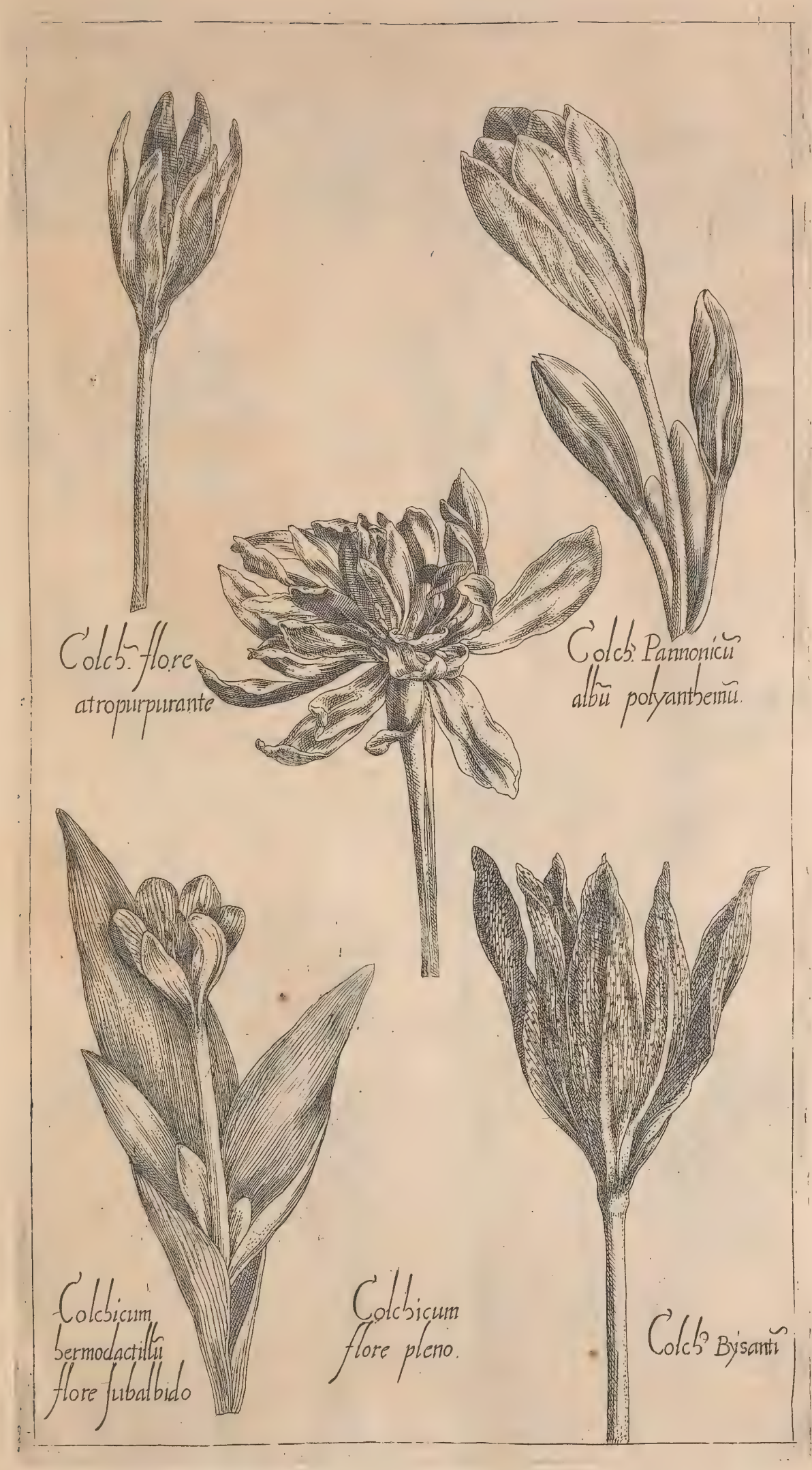





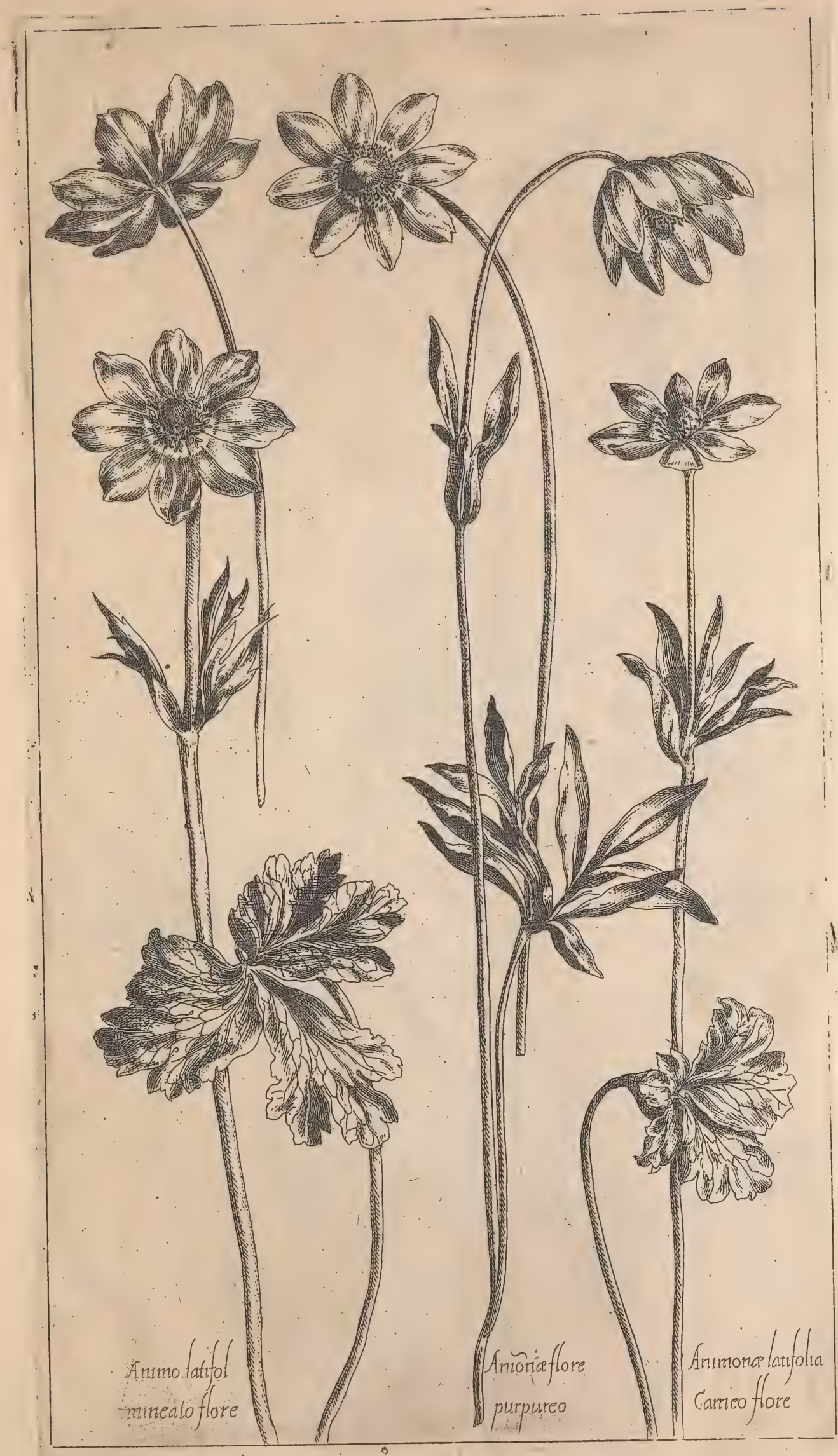



Crocus Autumnalis flo triolaceo

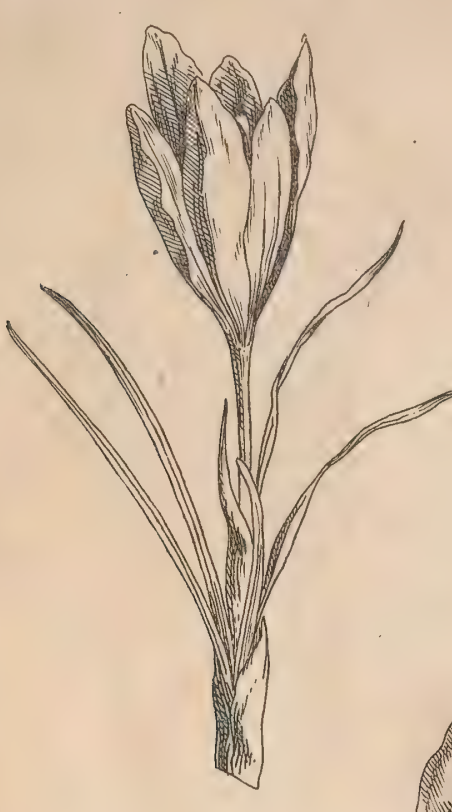

Colchicunt Tarreganiv polyantemus

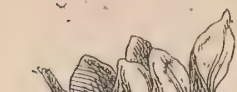
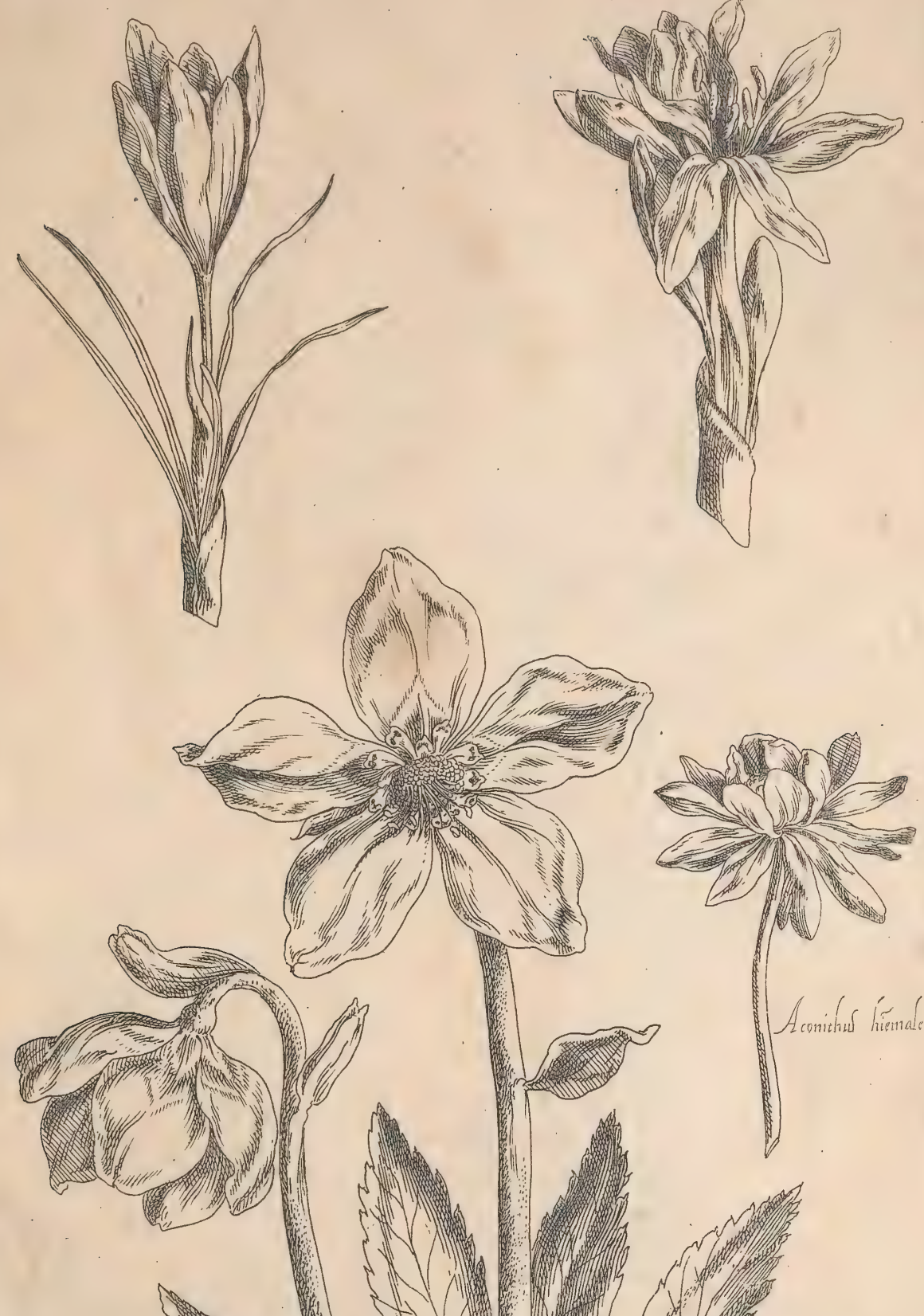

钭:
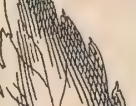

$\sqrt{m}$

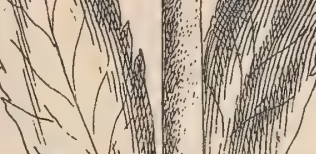

ing
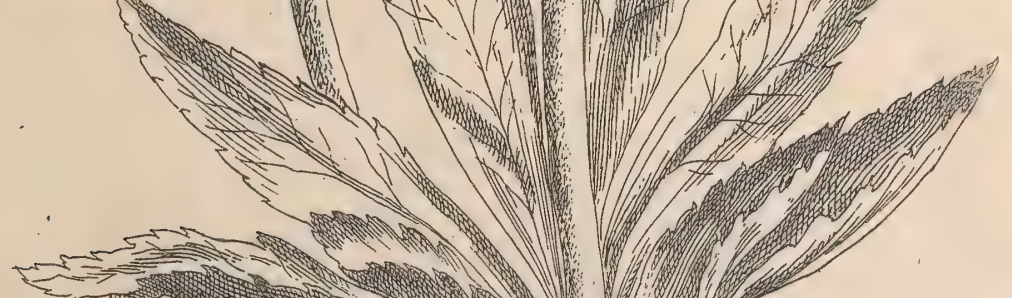

Eleborus Niger terus Theofhraw 



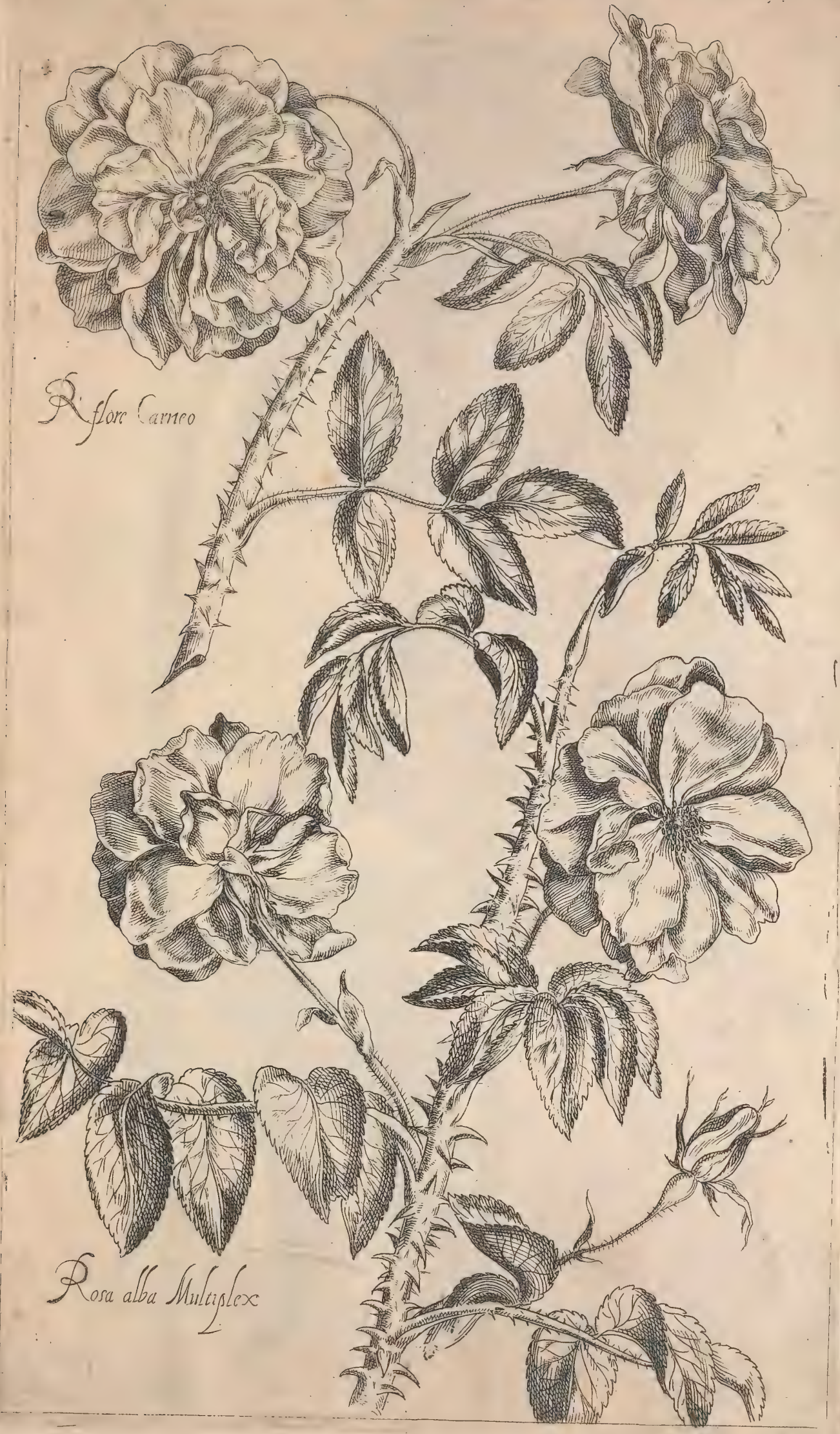





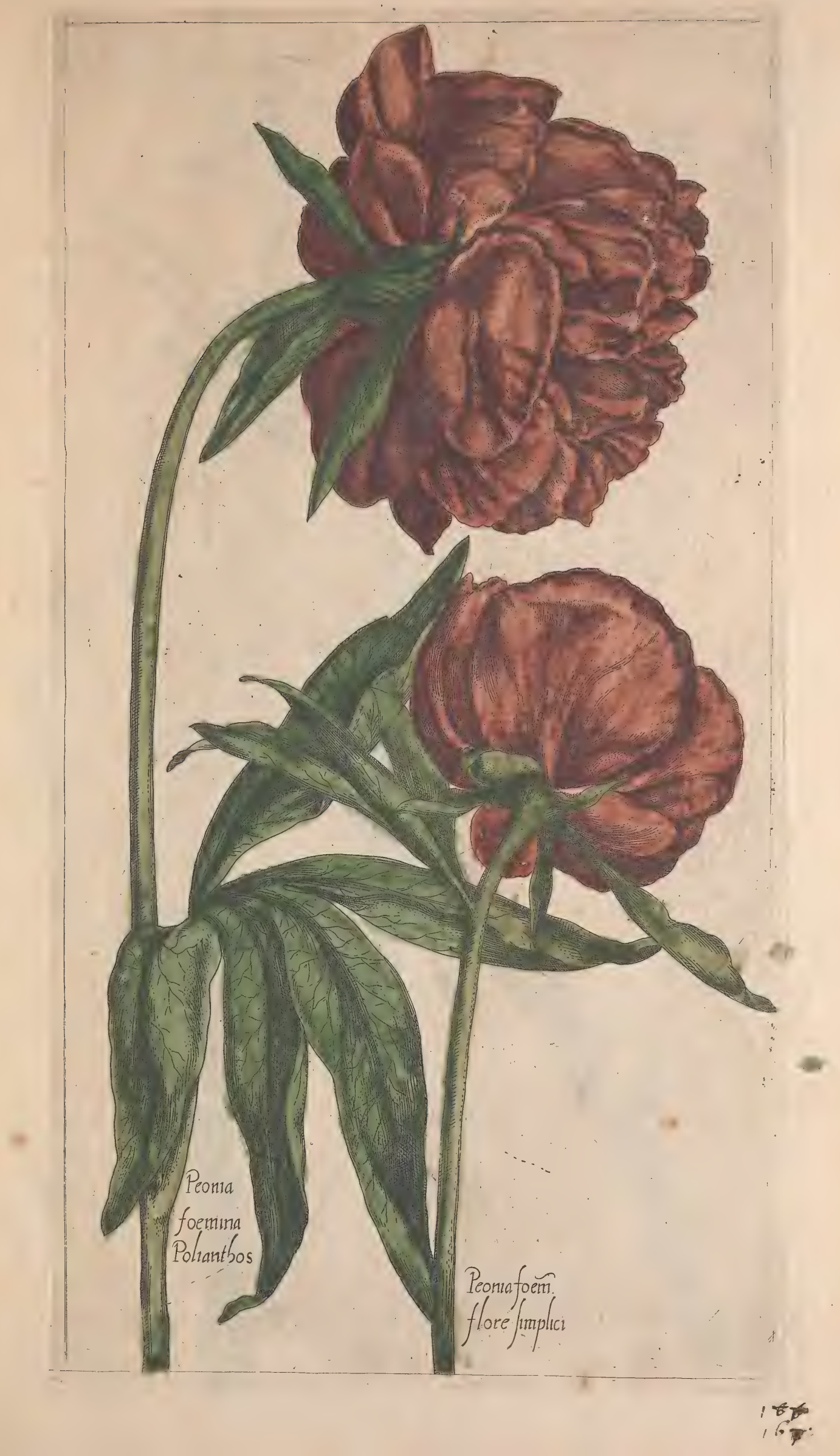





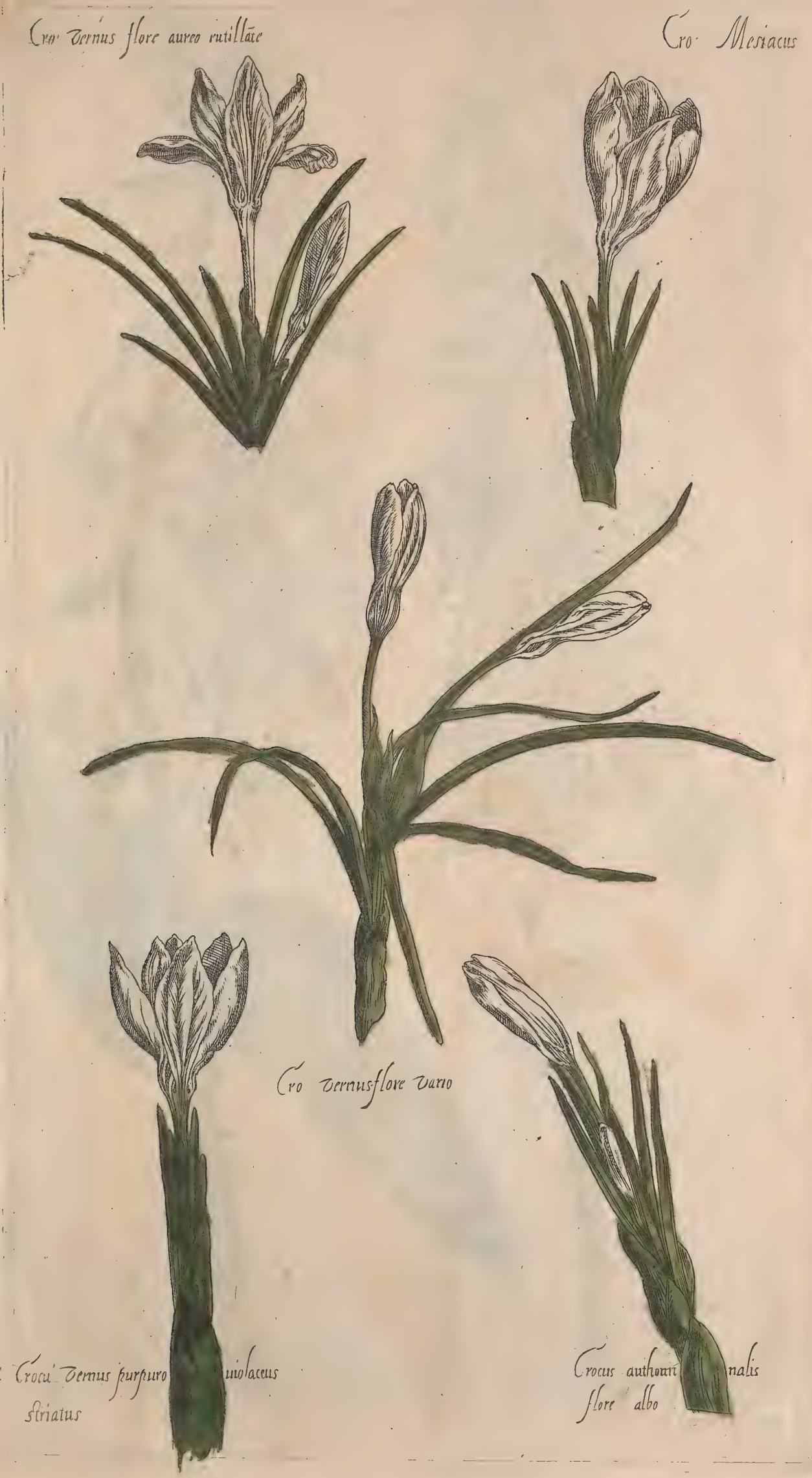




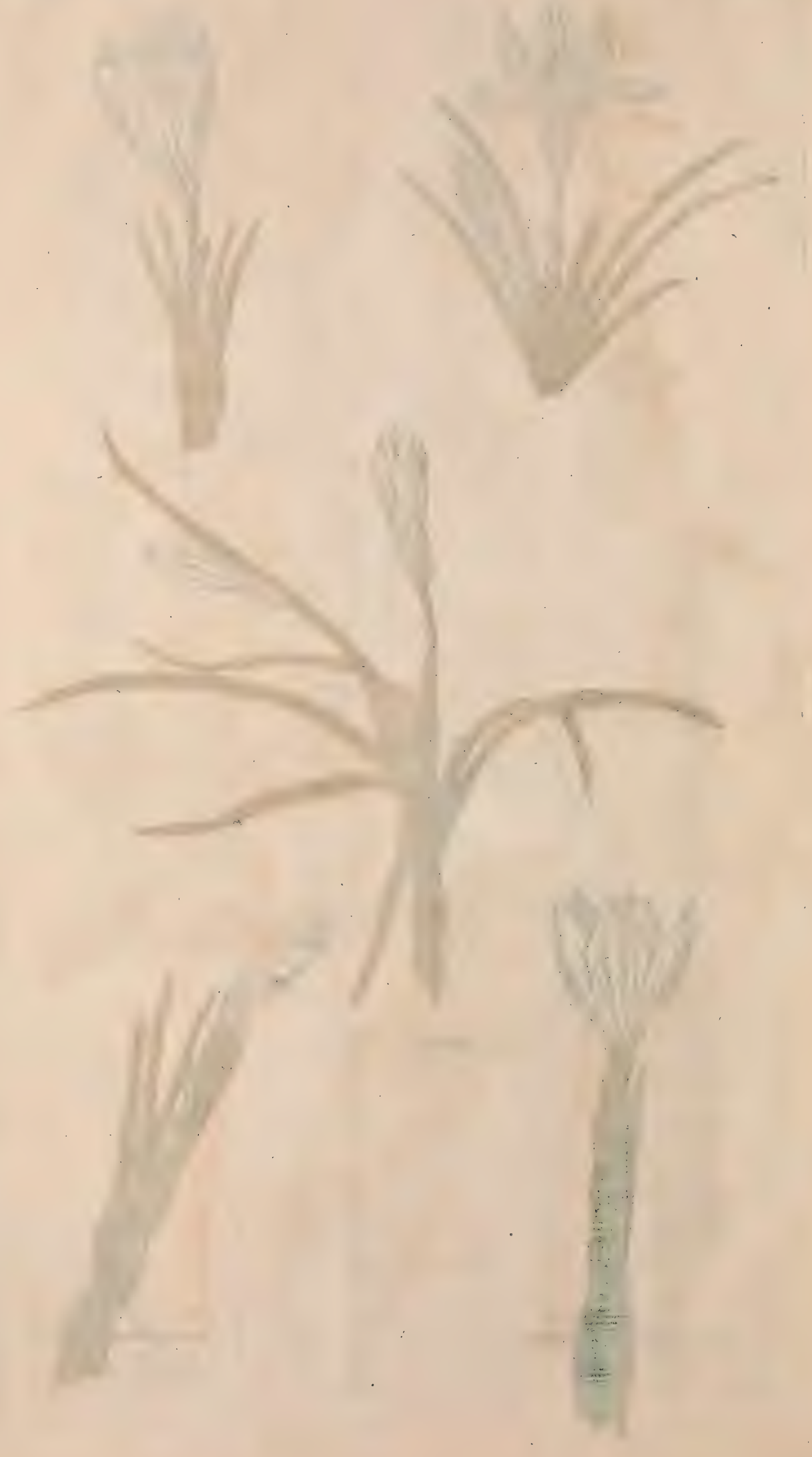




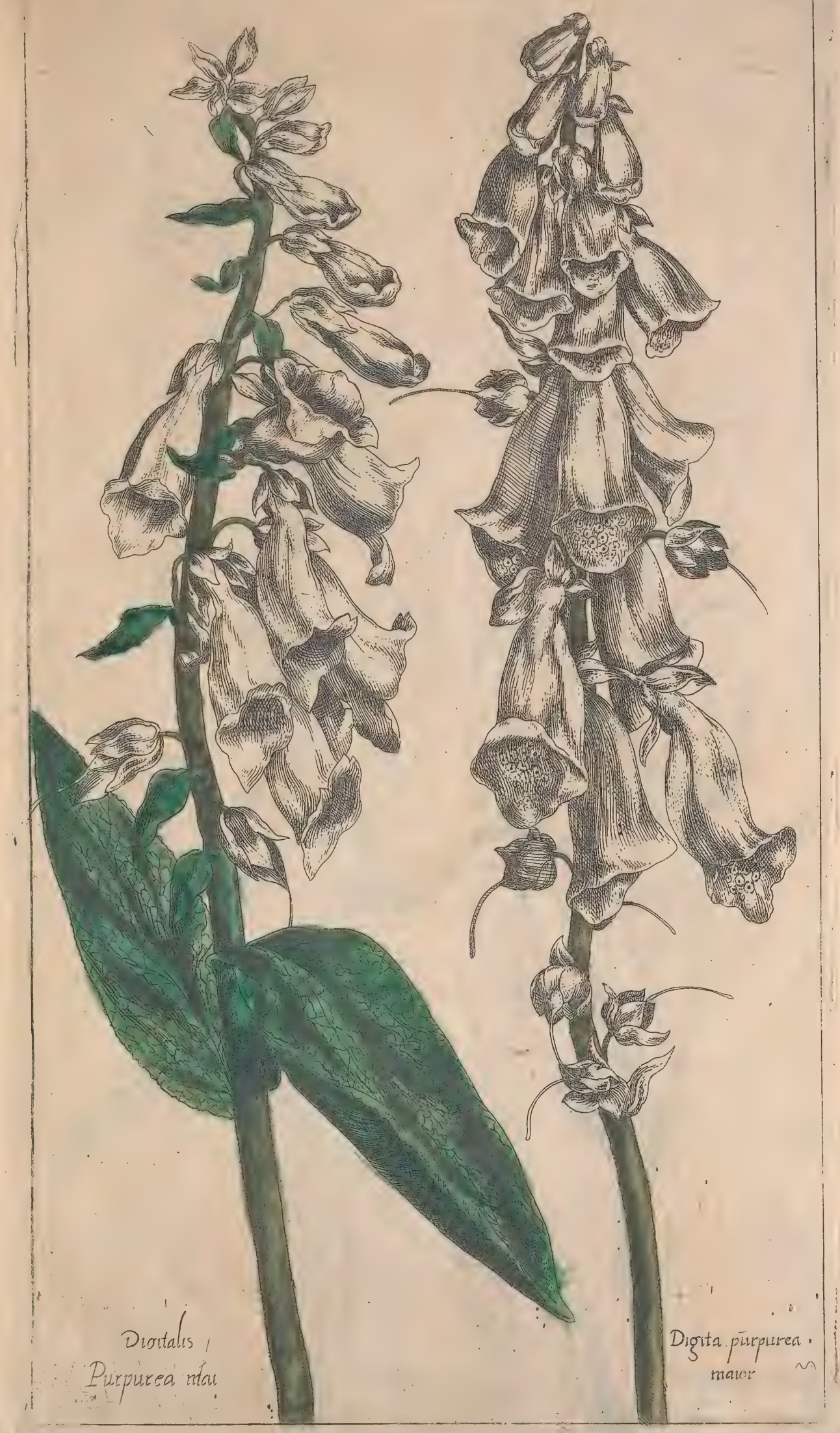




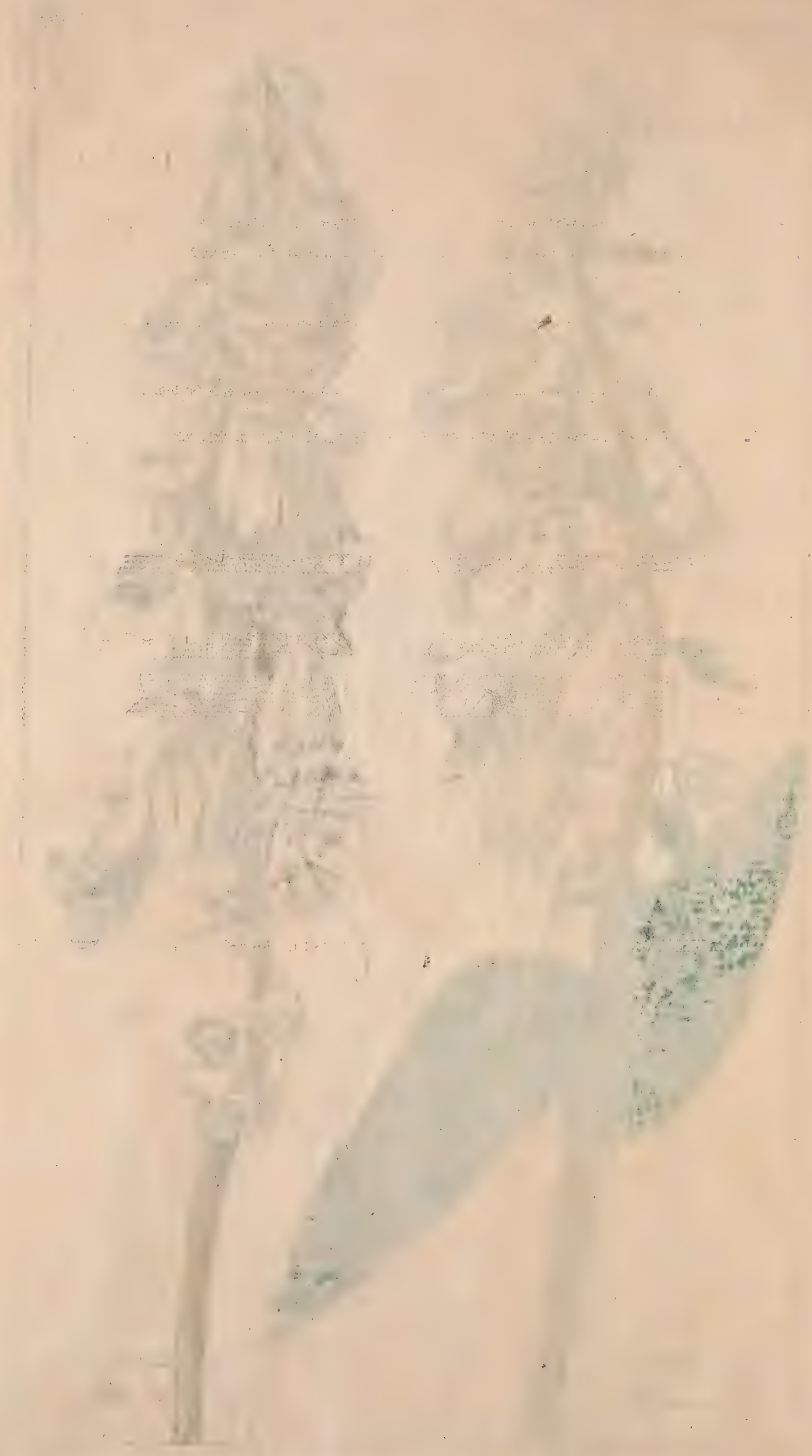




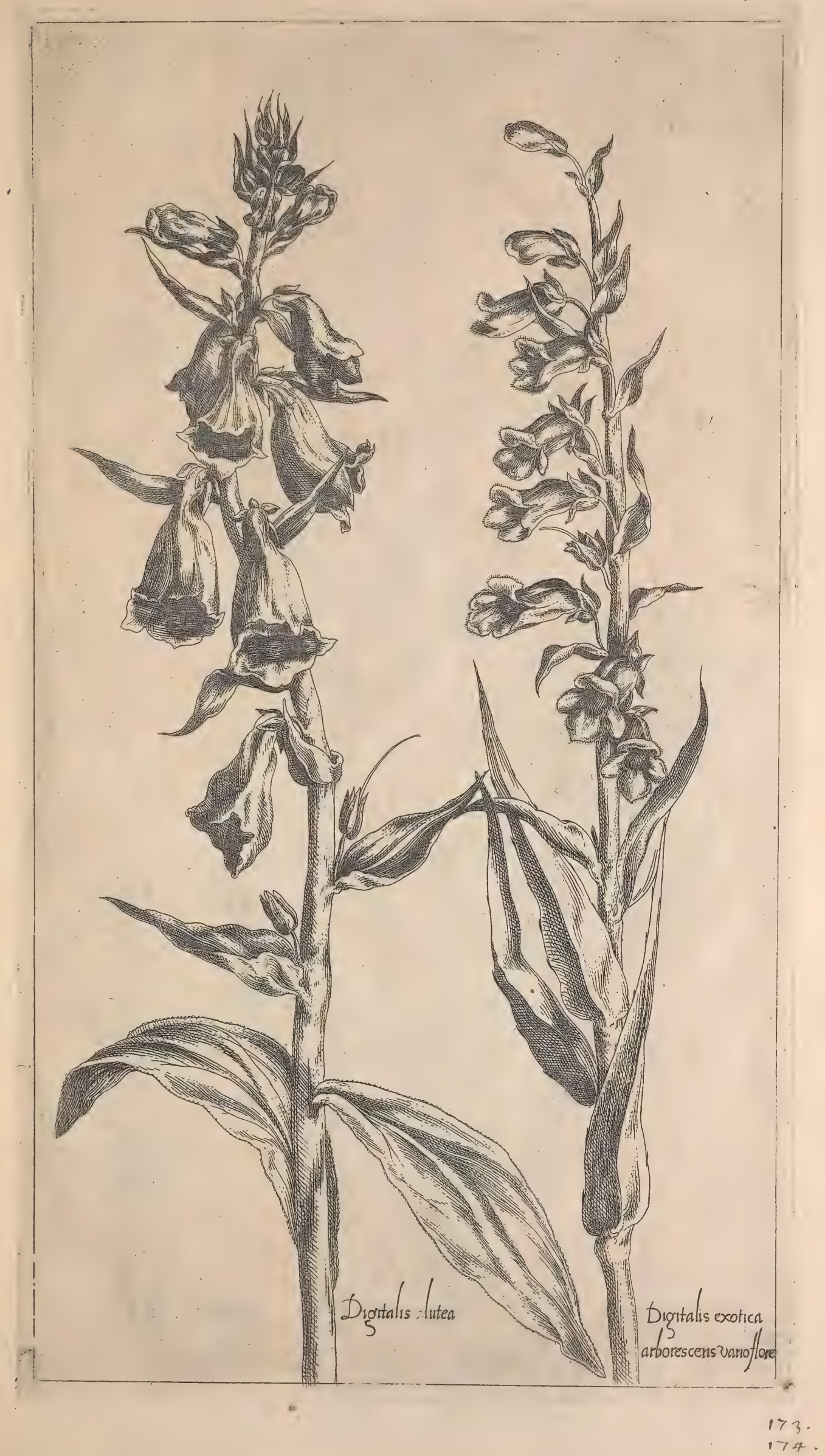





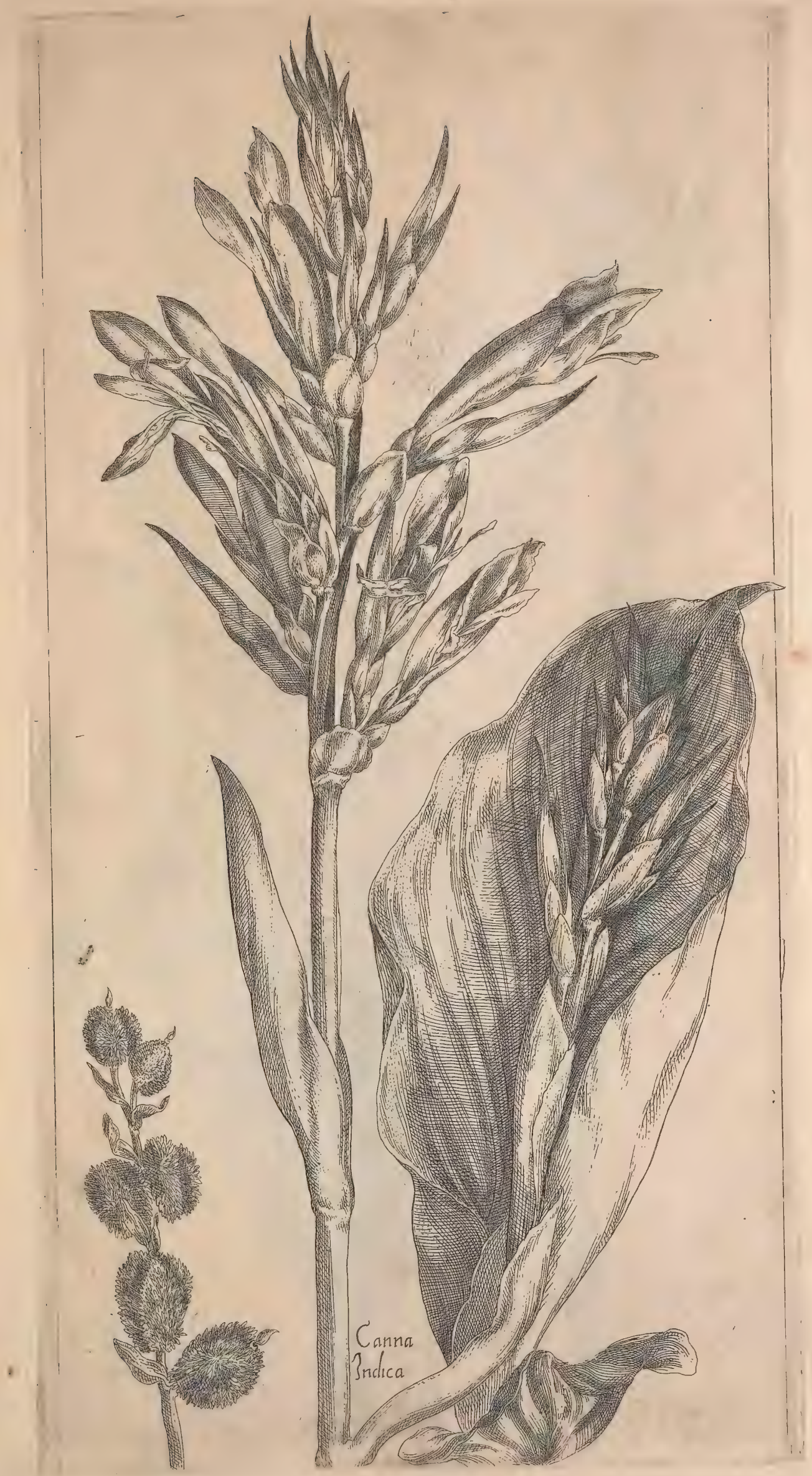





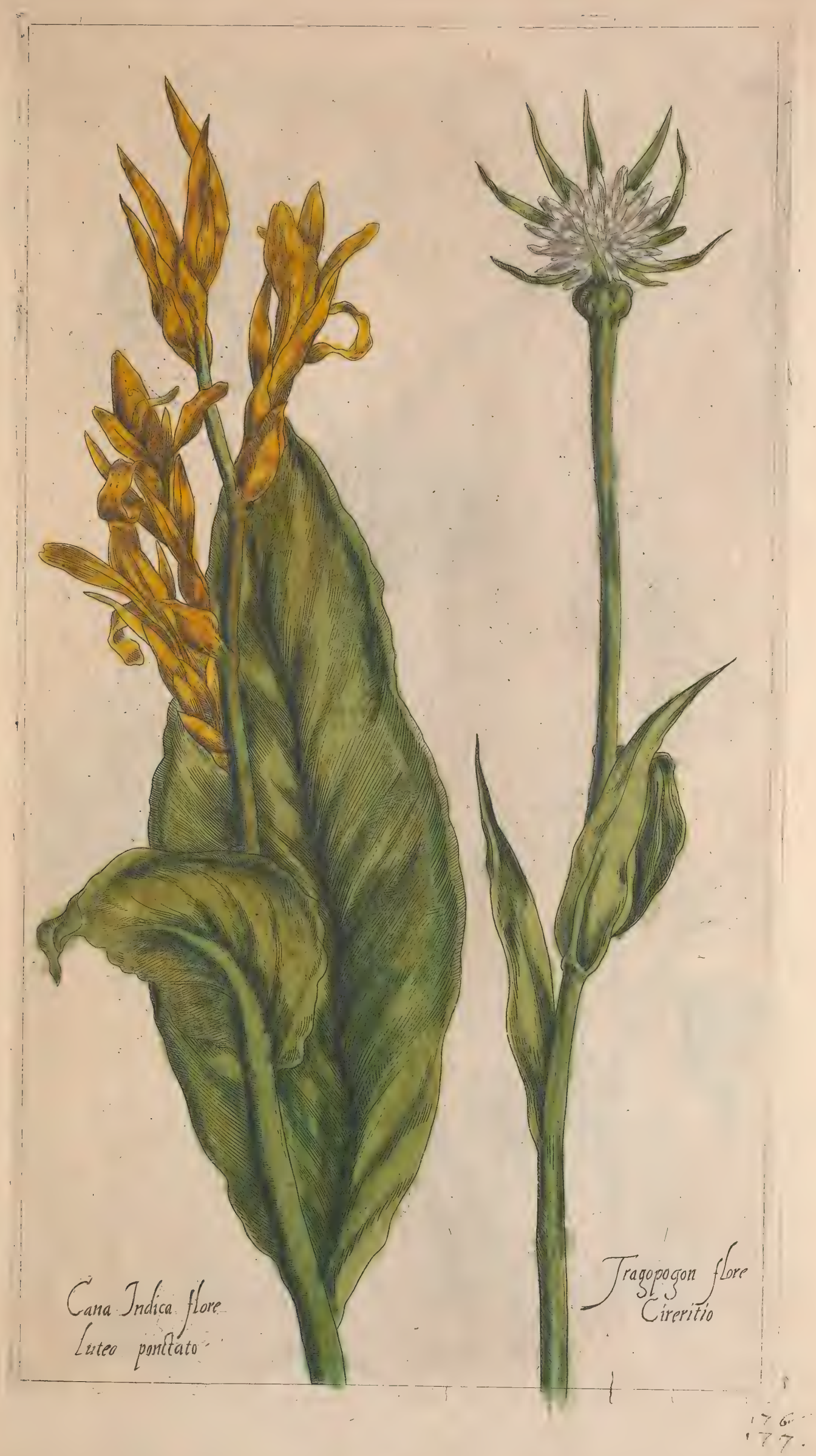





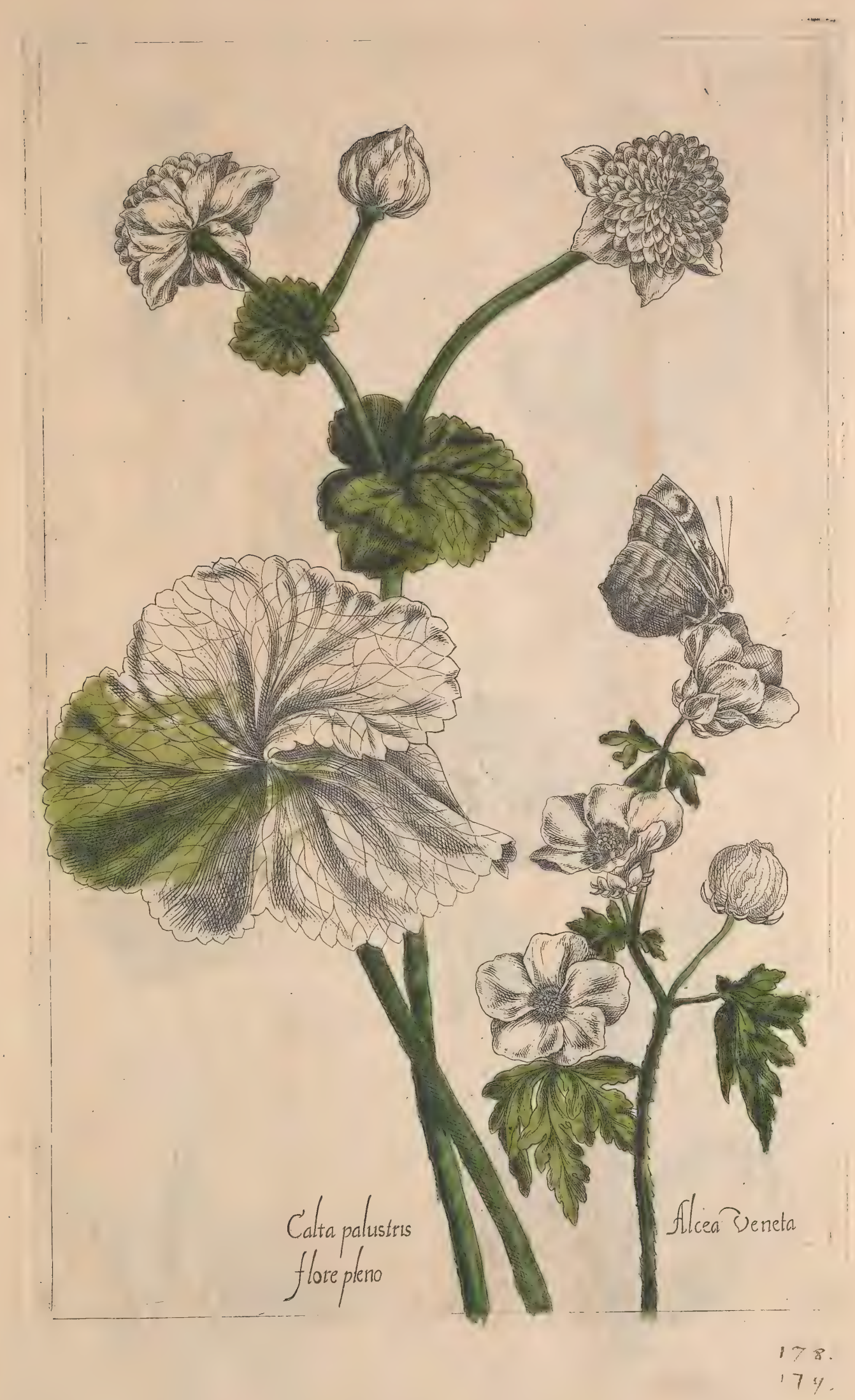




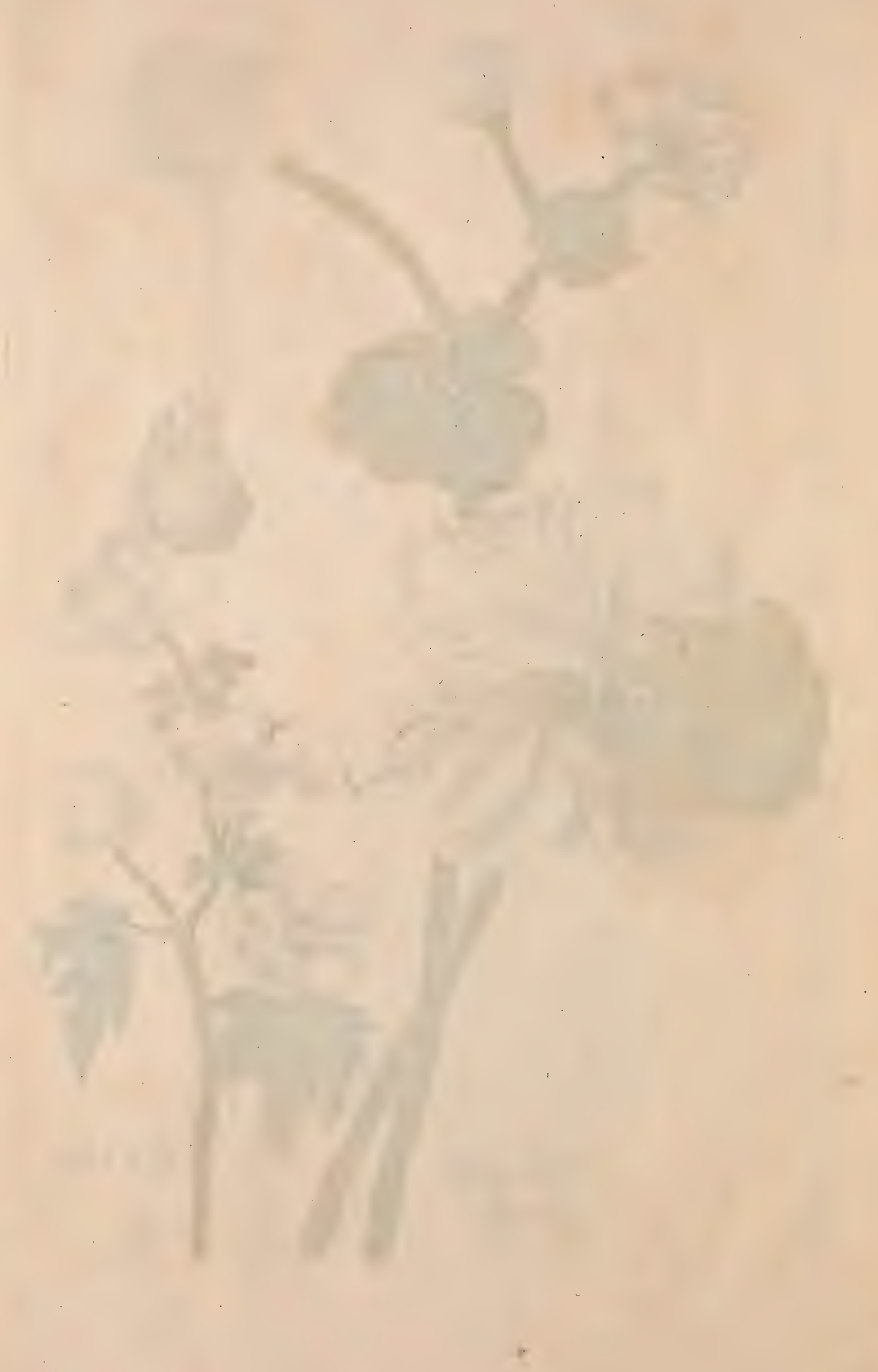




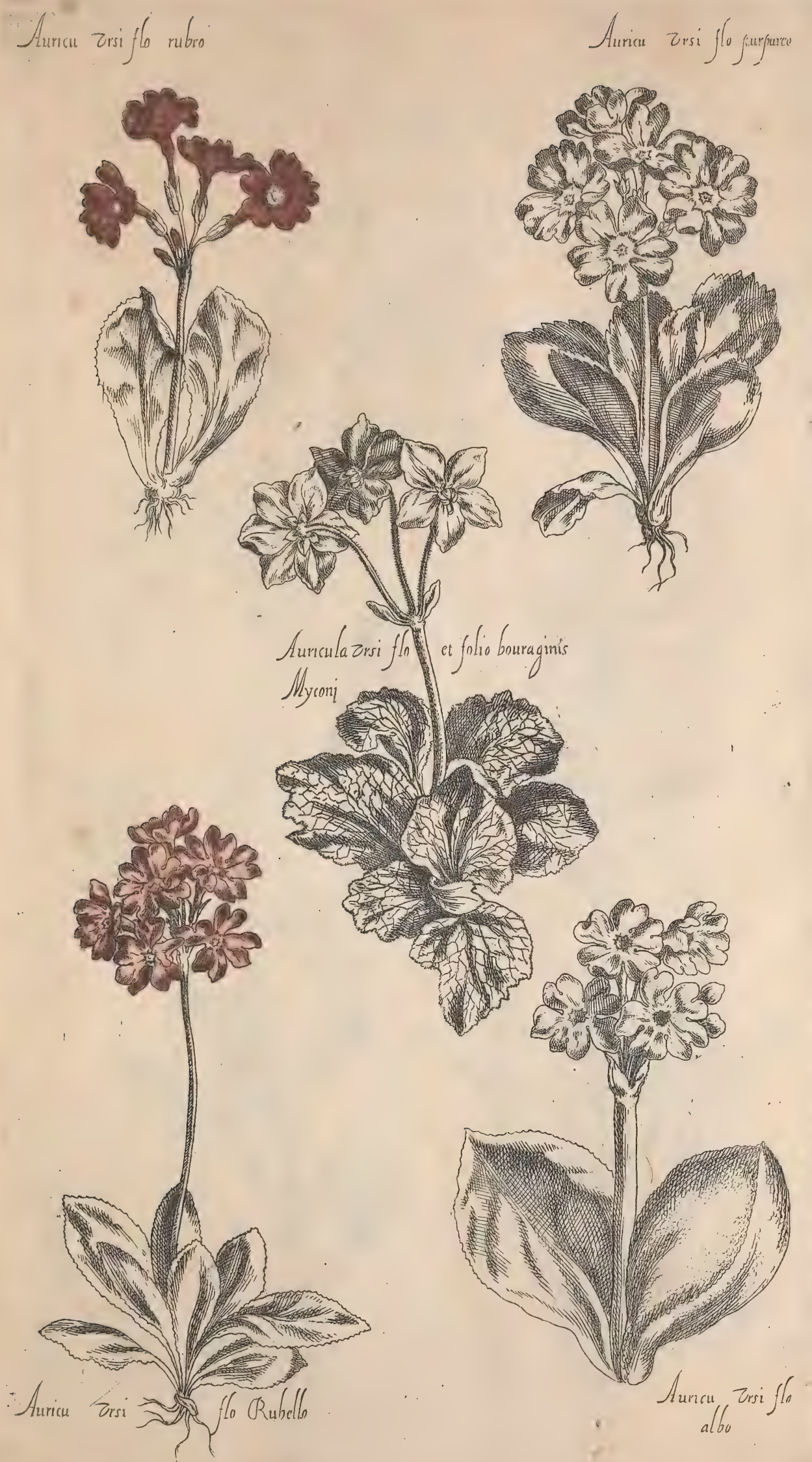





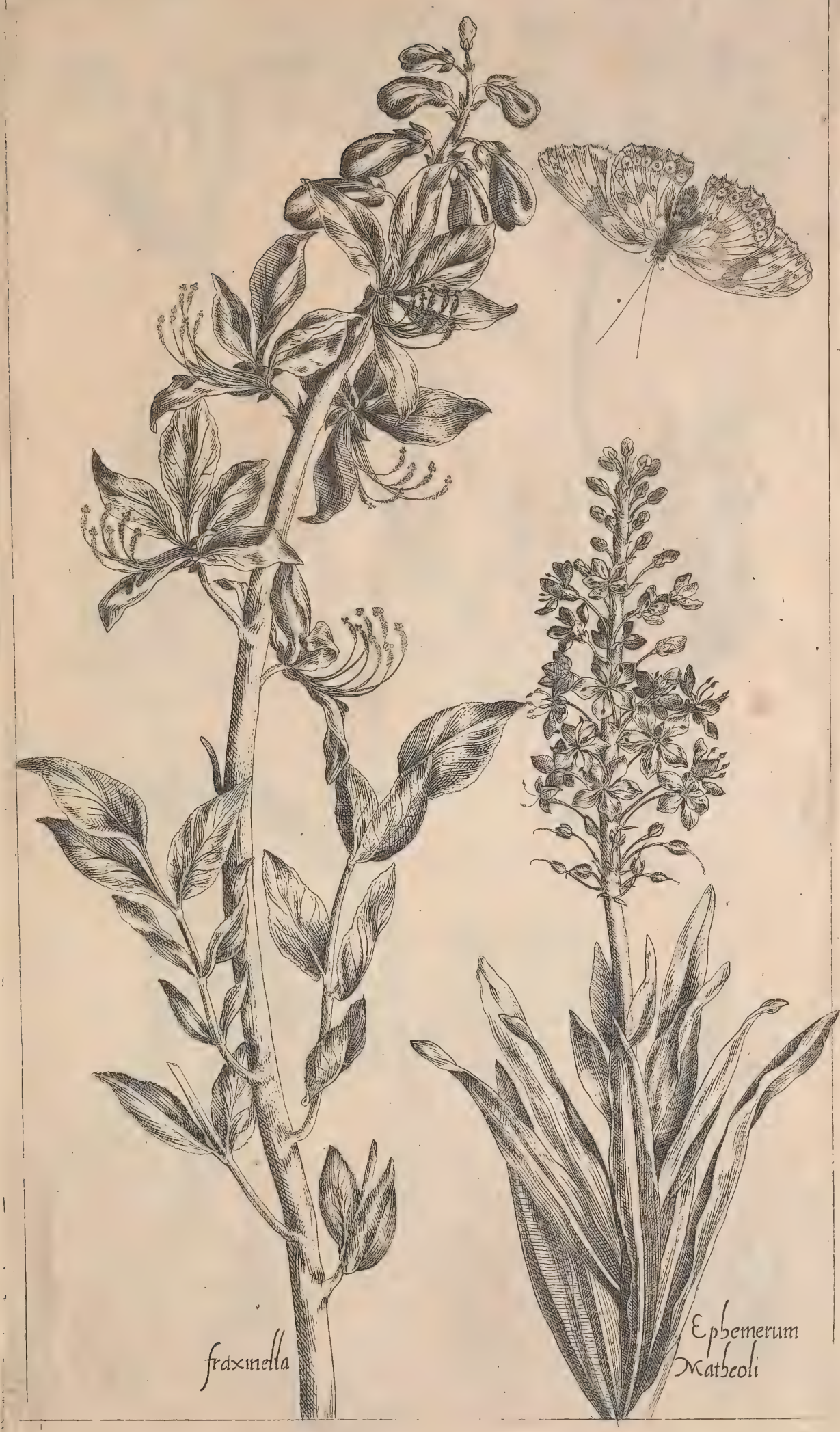





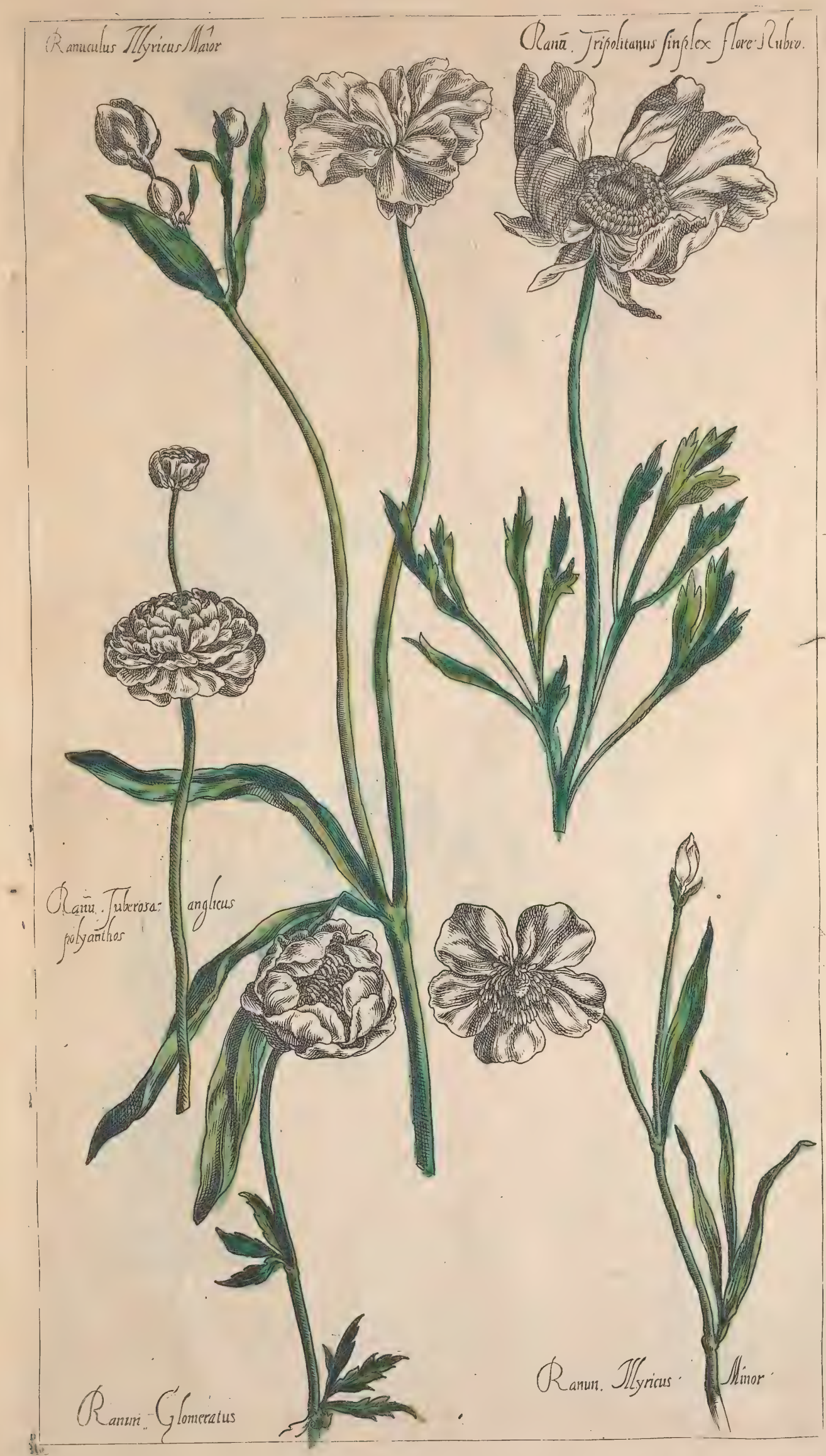





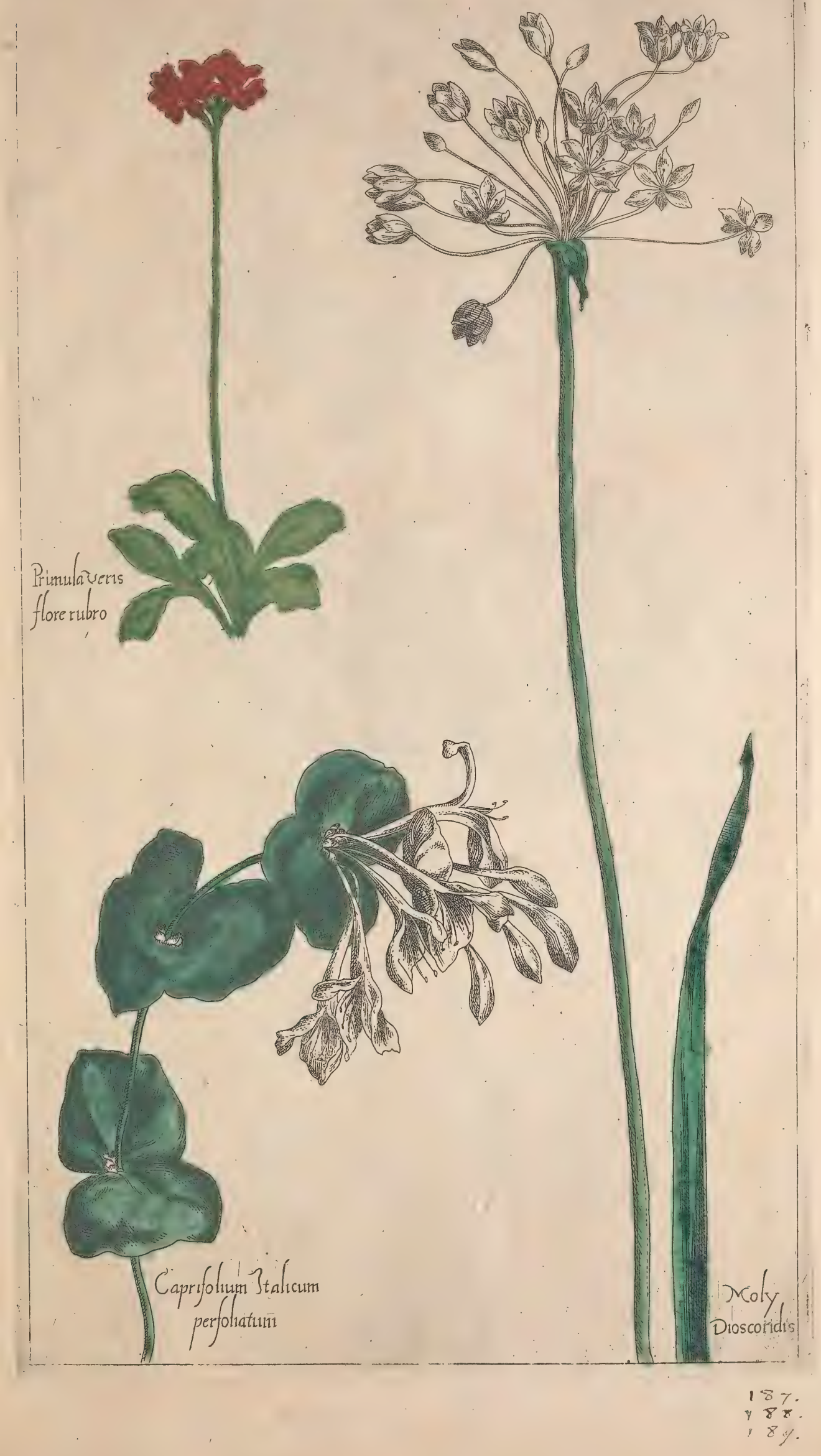





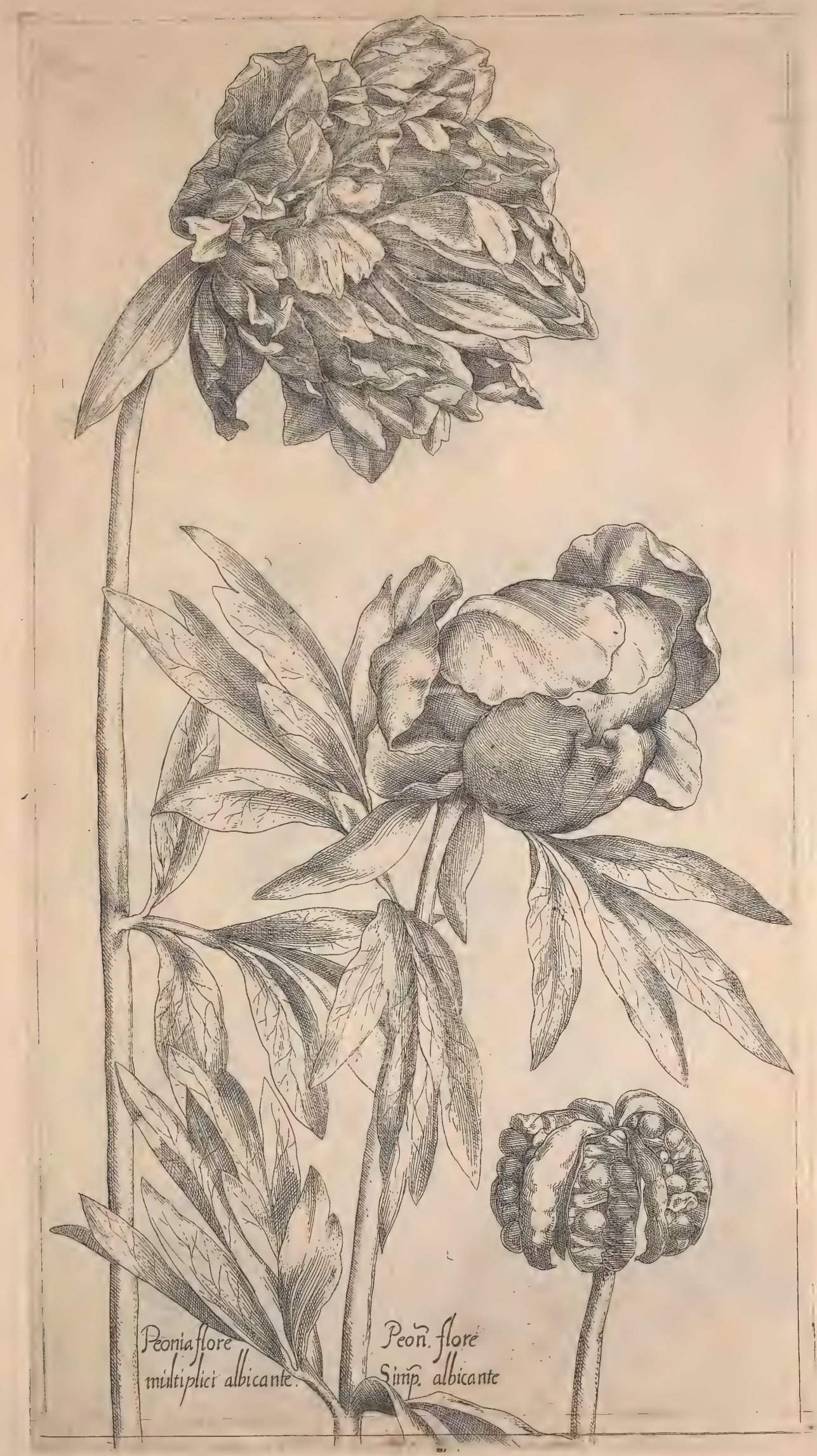





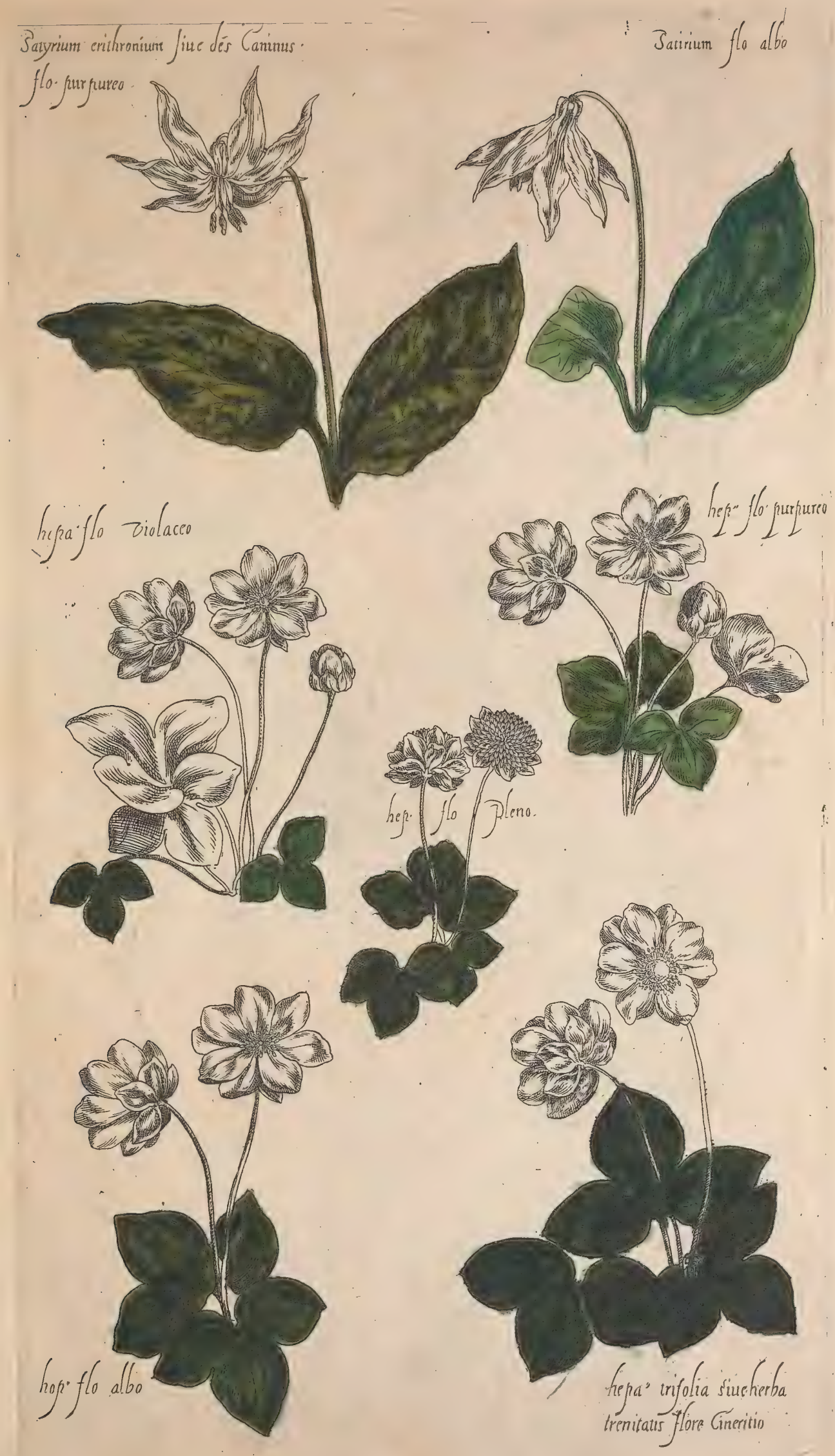





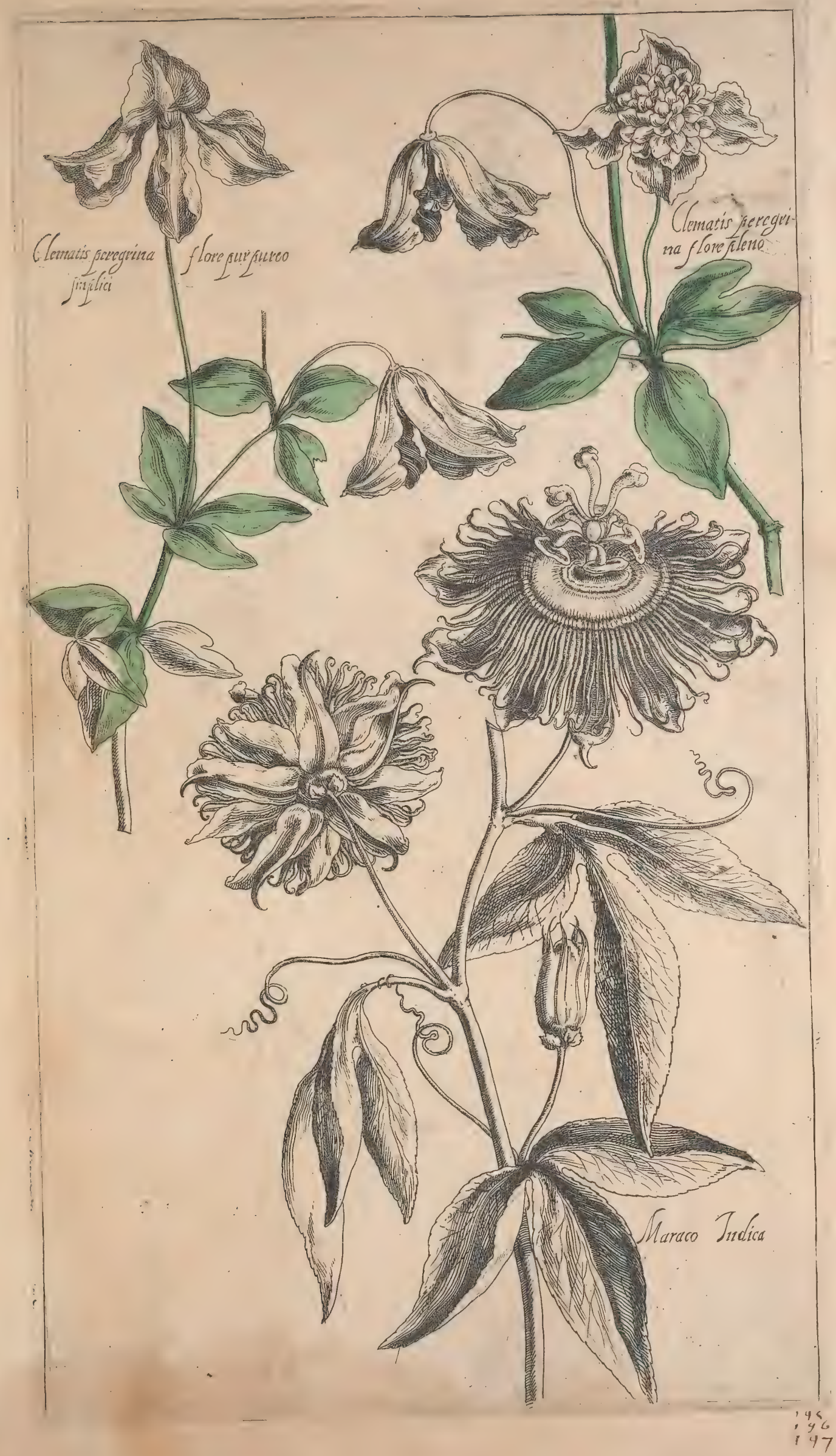





